Chary Ely Martin Marquez Batista

\title{
Avaliação da dor neuropática e das funções motora e somatossensitiva após o transplante de células tronco em modelo de lesão da medula espinal em ratos
}

Tese apresentada à Faculdade de Medicina da Universidade de São Paulo para obtenção do título de Doutor em Ciências

Programa de Neurologia

Orientador: Prof. Dr. Guilherme Alves Lepski

São Paulo 
Chary Ely Martin Marquez Batista

\section{Avaliação da dor neuropática e das funções motora e somatossensitiva após o transplante de células tronco em modelo de lesão da medula espinal em ratos}

Tese apresentada à Faculdade de Medicina da Universidade de São Paulo para obtenção do título de Doutor em Ciências

Programa de Neurologia

Orientador: Prof. Dr. Guilherme Alves Lepski

São Paulo 


\section{Dados Internacionais de Catalogação na Publicação (CIP)}

\section{Preparada pela Biblioteca da}

Faculdade de Medicina da Universidade de Săo Paulo

Creprodução autorizada pelo autor

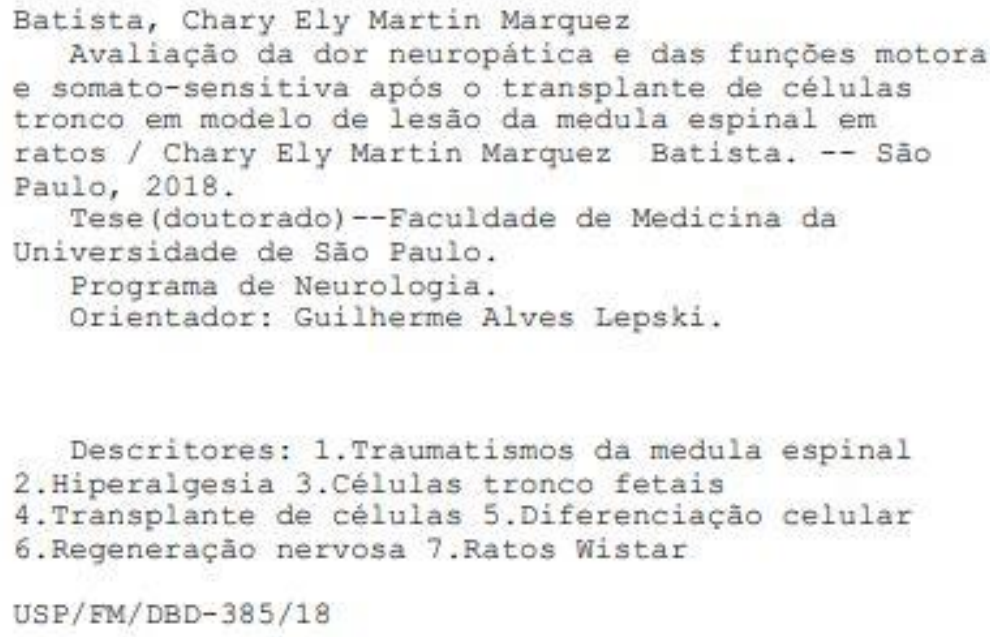

Responsável: Eidi Raquel Franco Abdalla - CRB-8/4901 


\section{Dedicatória}

Aos meus pais, Clássio e Pepi, meus maiores exemplos de vida, por todo amor, carinho e pela inestimável construção de valores que carregarei por toda a minha vida.

Ao meu companheiro de vida e de bancada, Eric Mariano, por acreditar em mim, por impulsionar meus sonhos e pela luta constante pelos nossos objetivos. A caminhada é mais prazerosa com você ao meu lado. 


\section{Agradecimentos}

Ao Prof. Dr. Guilherme Lepski, por compartilhar os seus conhecimentos, sempre incentivando e impulsionando o meu crescimento dentro dos desafios propostos. Agradeço a confiança.

Aos professores Dr. Alexandre Fogaça Cristante, Dra. Camila Squarzoni Dale e Dr. José Pinhata Otoch, pela grande contribuição no decorrer desse experimento, mediante valiosas sugestões, disponibilização de infraestrutura e de apoio técnico.

À Junko Osaka, pela amizade, por todo apoio ao longo desse período e pelas valiosas dicas e ensinamentos.

Aos funcionários da técnica cirúrgica que, além do carinho, auxiliaram-me durante esse projeto sempre que necessário.

Aos meus amigos Breno Barbosa, Rodrigo Watanabe e Sâmia Wayhs, pela excelente companhia dentro e fora da pesquisa, pelos bons momentos compartilhados.

À Analía Arevalo, pela amizade, por todo ensinamento e valiosas discussões acadêmicas.

Aos amigos do curso de neurociências, Carlos Buzó, Daniela Del Giorno, Estefania Simoes, Fernanda Coutinho, Hilka Neves, Jane Santos, Jonas Silva, Juan Carlos Monasterio, Mayra Gaiato, Míriam Yassuda, Mirian Cardoso, Morgani Rodrigues, Roseli Araújo, Rosemary Mantovani, Sueli Mainine e Zina Zupo, por todo apoio dado durante o caminho que trilhamos juntos.

Aos meus raios de sol em dias de chuva, meus sobrinhos Leonora, Monolo, Nayla, Micaely e Javier.

À minha família, minha fortaleza, pelo apoio constante na busca de meus sonhos.

À FAPESP (2015/02154-0) e CNPq (140381/2015-5).

"Aqueles que passam por nós não vão sós, não nos deixam sós. Deixam um pouco de si, levam um pouco de nós". Antoine de Saint-Exupéry 
"La science, mongarçon, est faite d'erreurs, mais ce sont des erreurs qu'il est utile de faire, parce qu'elles conduisent peu à peu à la vérité".

Jules Verne

"A ciência, meu rapaz, é feita de erros, mas estes são erros úteis de serem cometidos, pois conduzem pouco a pouco à verdade."

Júlio Verne 
Esta dissertação está de acordo com as seguintes normas, em vigor no momento desta publicação:

Referências: adaptado de International Committee of Medical Journals Editors (Vancouver).

Universidade de São Paulo. Faculdade de Medicina. Divisão de Biblioteca e Documentação. Guia de apresentação de dissertações, teses e monografias. Elaborado por Anneliese Carneiro da Cunha, Maria Julia de A. L. Freddi, Maria F. Crestana, Marinalva de Souza Aragão, Suely Campos Cardoso, Valéria Vilhena. 3a ed. São Paulo: Divisão de Biblioteca e Documentação; 2011.

Abreviaturas dos títulos dos periódicos de acordo com List of Journals Indexed in Index Medicus. 


\section{SUMÁRIO}

\section{LISTA DE TABELAS}

LISTA DE FIGURAS

RESUMO

\section{ABSTRACT}

1. INTRODUÇÃO

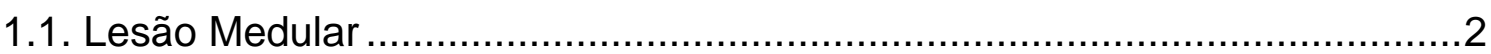

1.2. Alterações Associadas à Lesão Medular ......................................................

1.2.1. Comprometimento Sensório Motor..................................................

1.2.2. Disfunções Autonômicas ................................................................10

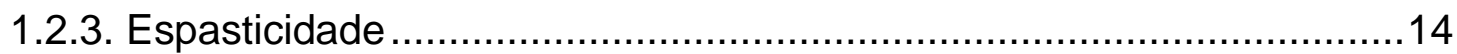

1.2.4. Dor Após Lesão Medular...............................................................16

1.2.4.1. Dor Neuropática........................................................................17

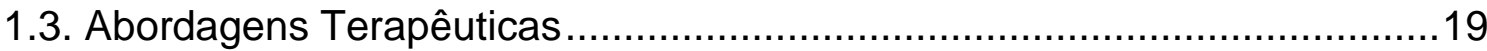

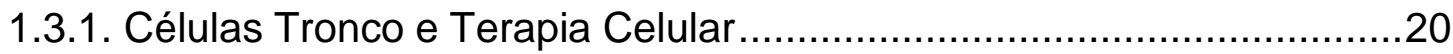

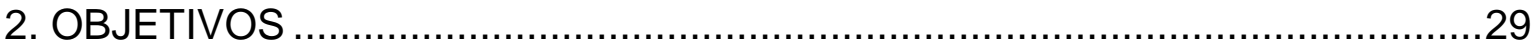

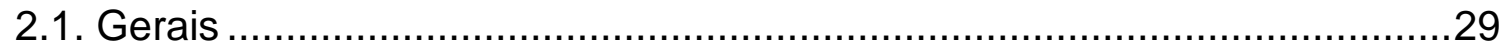

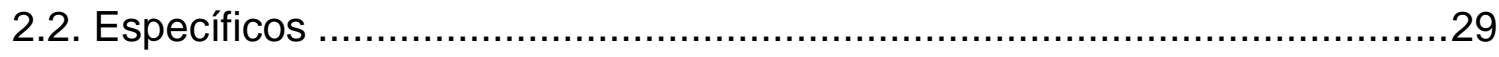

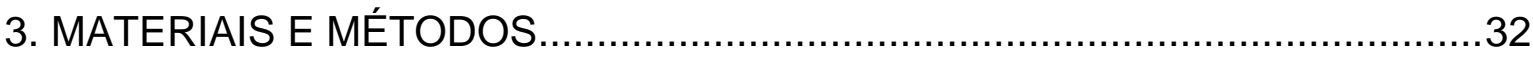

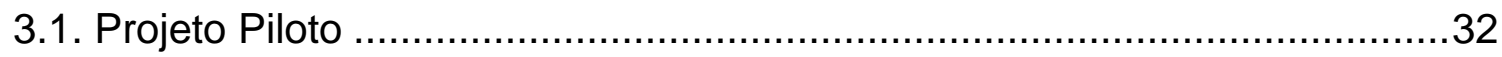

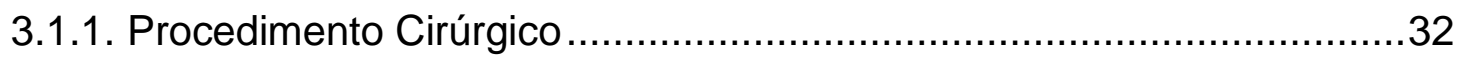

3.1.1.1. Grupos Experimentais do Piloto ……………..........................33

3.1.2. Índice de Recuperação Vesical .........................................................

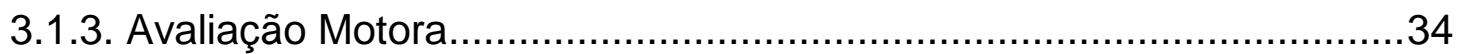

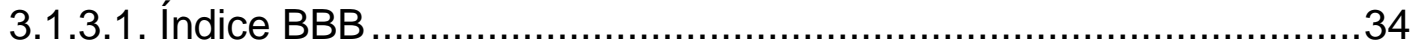




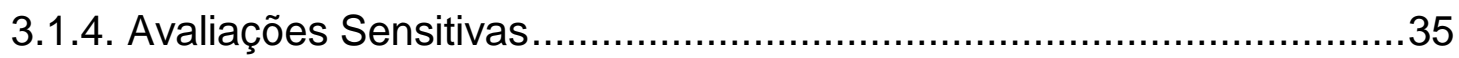

3.1.4.1. Filamentos de Von Frey ..................................................................

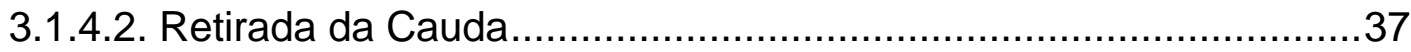

3.1.5. Imunofluorescência e Imunohistoquímica .........................................37

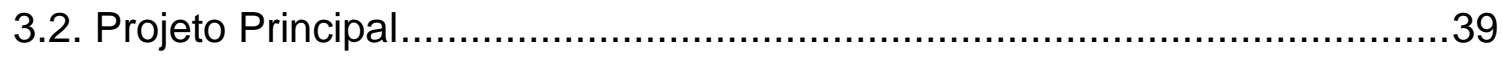

3.2.1. Isolamento das Células Tronco Neurais Fetais .................................39

3.2.2. Procedimento Cirúgico ……………………................................. 41

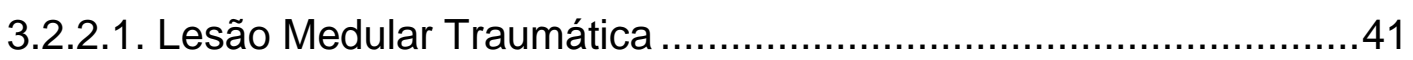

3.2.2.2. Imunossupressão ................................................................ 41

3.2.2.3. Transplante Celular ................................................................ 42

3.2.2.4. Grupos Experimentais do Projeto ...............................................4 43

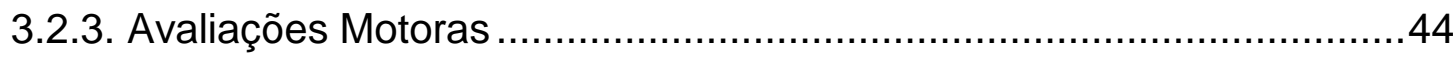

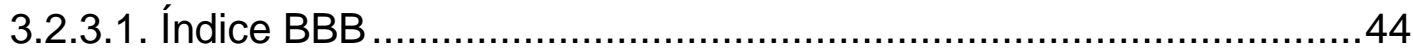

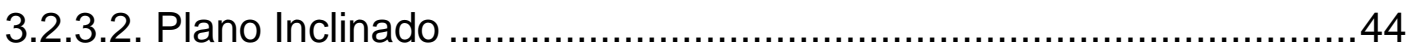

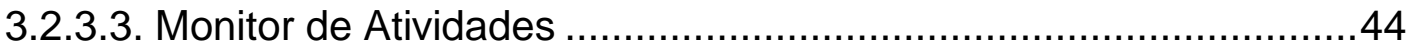

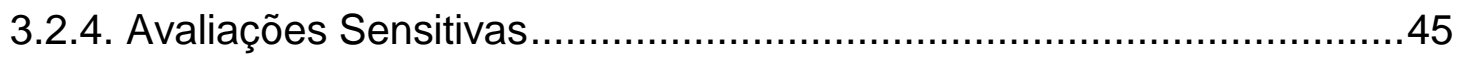

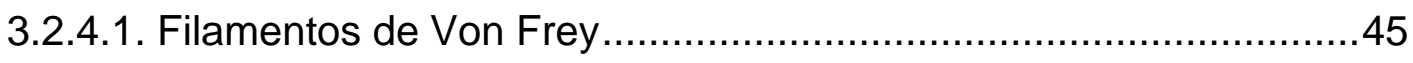

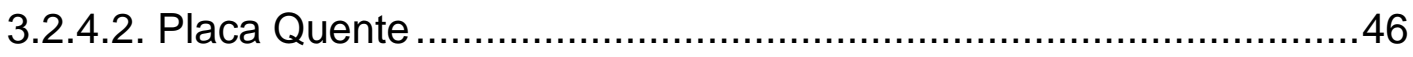

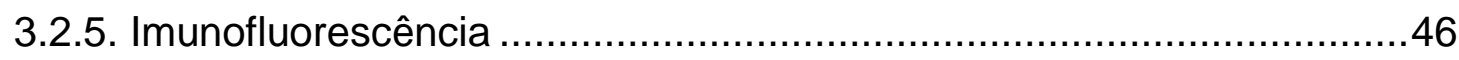

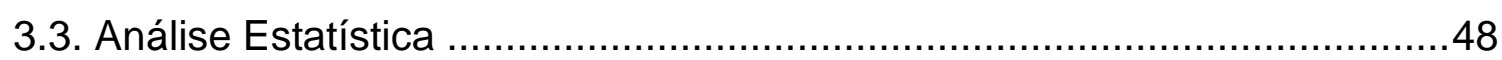

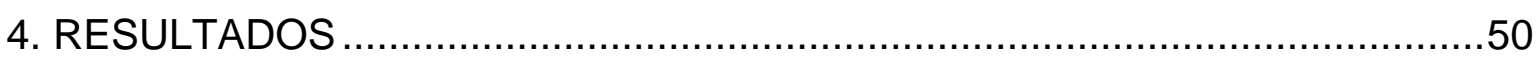

4.1. Resultados do Projeto Piloto .................................................................

4.1.1. Análise do Peso Corporal e da Recuperação Vesical ...........................50

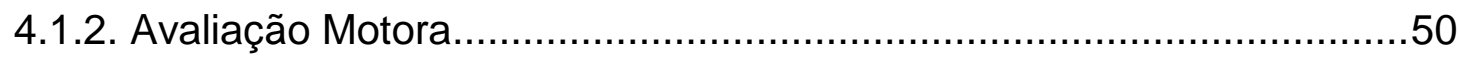

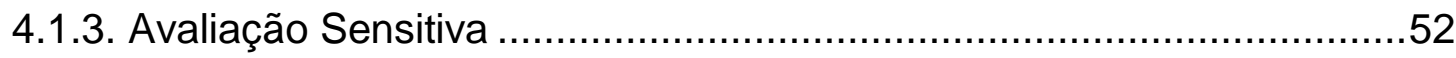

4.1.4. Imunofluorescência/Imunohistoquímica ..........................................54 


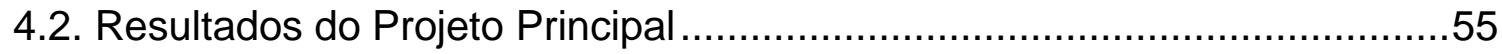

4.2.1. Análise da Sobrevivência e do Peso Corporal ..................................55

4.2.2. Avaliação Motora...................................................................... 56

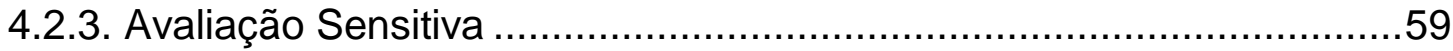

4.2.4. Imunofluorescência e Quantificação Estereológica............................61

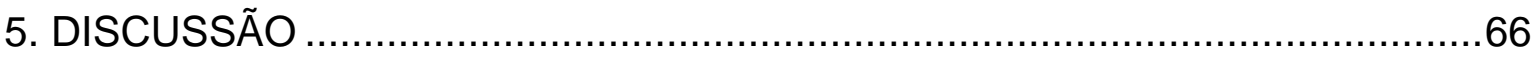

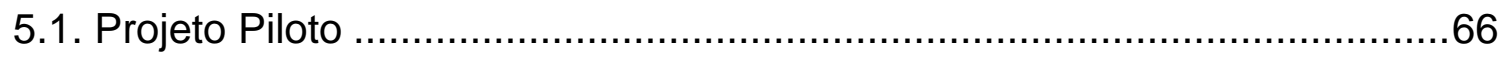

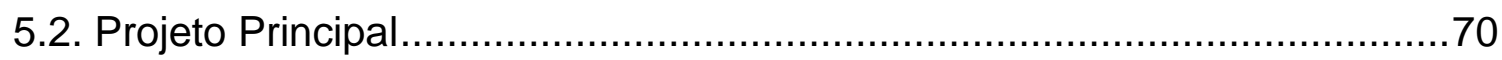

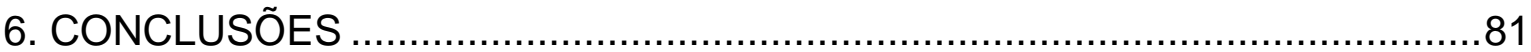

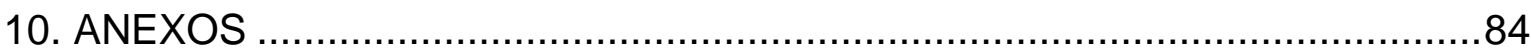

10.1. Aprovação do Comitê de Ética …...................................................... 84

10.2. Dados Estatísticos do Projeto Piloto ................................................... 86

10.3. Dados Estatísticos do Projeto Principal ................................................89

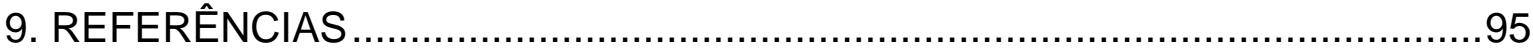




\section{LISTA DE TABELAS}

Tabela 1: Classificação da dor após lesão medular.................................... 17

Tabela 2: Relação do tamanho da bexiga vs. grau de recuperação vesical 34

Tabela 3: Escala locomotora BBB....................................................... 36

Tabela 4: Espessura vs. força em gramas de cada filamento de von Frey.. 37 


\section{LISTA DE FIGURAS}

Figura 1: Fases da lesão medular e principais eventos fisiopatológicos......... 8

Figura 2: Esquema representativo de diferentes fontes de células tronco e abordagens para o reparo da medula espinal após lesão.

Figura 3: Animal posicionado no aparelho NYU Impactor.

Figura 4: Extração e cultura de células tronco neurais fetais (CTNf) de embriões com 14 dias de vida intra-uterina

Figura 5: Animal posicionado no aparelho estereotáxico para receber a injeção das células tronco neurais fetais.

Figura 6: Avaliações motoras

Figura 7: Avaliações sensitivas.

Figura 8: Análise do peso corporal, da função vesical e da locomoção através da escala BBB.

Figura 9: Avaliação da sensibilidade e o estabelecimento da alodínia mecânica nas patas traseiras.

Figura 10: Quantificação da extensão da lesão medular através da coloração com hematoxilina-eosina.

Figura 11: Quantificação estereológica de neurônios neuN positivos.

Figura 12: Avaliação da sobrevivência e ganho de peso.

Figura 13: Avaliação da função motora

Figura 14: Avaliação do desempenho motor através do monitor de atividades. 58

Figura 15: Melhora da alodínia mecânica e da hiperalgesia térmica nos grupos tratados com células tronco neurais fetais.

Figura 16: Quantificação estereológica das células transplantadas na medula espinal. 
Figura 17: Fotomicrografias mostrando a diferenciação celular das células extraídas das vesículas telencefálicas (VT) e do bulbo ventral (BV) após o transplante da medula espinal lesada.

Figura 18: Fotomicrografias mostrando a diferenciação celular das células extraídas das vesículas telencefálicas (VT) e do bulbo ventral (BV) após o transplante da medula espinal lesada. 


\section{RESUMO}

Batista CEMM. Avaliação da dor neuropática e das funções motora e somatosensitiva após o transplante de células tronco em modelo de lesão da medula espinal em ratos [tese]. São Paulo: Faculdade de Medicina, Universidade de São Paulo; 2018.

A dor neuropática após lesão da medula espinal é uma condição complexa que responde mal aos tratamentos convencionais. $O$ transplante de células representa uma terapia promissora; no entanto, o tipo de célula ideal em termos de potencial neurogênico e eficácia contra a dor permanecem controversos. Assim, o objetivo do presente estudo foi avaliar a capacidade de células tronco neurais fetais (CTNf) em aliviar a dor crônica e, secundariamente, avaliar os efeitos na recuperação motora. Com este propósito, inicialmente foi realizado um piloto para definir o melhor modelo animal, no qual ratos Wistar foram submetidos à lesão medular traumática de intensidade leve ou moderada (altura do pêndulo $12,5 \mathrm{~mm}$ e $25 \mathrm{~mm}$, respectivamente) utilizando o NYU Impactor. Os resultados indicaram que a lesão medular de intensidade moderada é um bom modelo para o estudo da dor neuropática central, pois, além de apresentar um déficit motor e um quadro álgico mais acentuado que os animais submetidos à lesão leve, os animais se mantiveram estáveis ao longo do estudo. Ademais, alterações sensoriais foram observadas desde os primeiros dias após a lesão e permaneceram por pelo menos oito semanas, viabilizando o objetivo do trabalho. Em vista do resultado do piloto, ratos Wistar foram submetidos à lesão medular de itensidade moderada; sete dias após a lesão medular iniciou-se a imunossupressão com ciclosporina, e dez dias após a lesão os animais receberam injeções intra-espinais de meio de cultivo (grupo sham) ou de CTNf extraídas das vesículas telencefálicas (grupo VT) ou da região ponto-bulbar ventral (grupo BV) de embriões E14 da mesma espécie. As avaliações sensitivas e motoras foram realizadas durante oito semanas. Posteriormente, as medulas espinais foram processadas para imunofluorescência e as CTNf transplantadas foram quantificadas por estereologia. Os resultados mostraram uma melhora da hiperalgesia térmica no grupo VT após a quinta semana de transplante $(p<0,001)$ e no grupo BV após a quarta semana $(p<0,001)$. Além disso, a alodínia mecânica melhorou nos grupos VT e BV na 8 ${ }^{\underline{a}}$ semana (VT $p<0,05$ e BV $p<0,01$ comparados com sham). Nenhuma recuperação motora significativa foi observada nos grupos tratados em relação ao grupo sham. A análise estereológica mostrou que $\sim 70 \%$ das células VT e BV diferenciaram-se em neurônios $\mathrm{NeuN+}$, com alta proporção de células encefalinérgicas e GABAérgicas no grupo VT (44\% e $42 \%$, respectivamente) e encefalinérgicas e serotoninérgicas no grupo BV (50\% e $47 \%$, respectivamente). Nosso estudo sugere que os precursores neuronais oriundos das VT e BV, uma vez implantados na medula espinal lesada, maturam em diferentes subtipos neuronais, principalmente GABAérgicos, serotoninérgicos e encefalinérgicos, e ambos precursores foram capazes de aliviar a dor, apesar de não haver recuperação motora significativa.

Descritores: traumatismos da medula espinal; hiperalgesia; células tronco fetais; transplante de células; diferenciação celular; regeneração nervosa; ratos Wistar. 


\section{ABSTRACT}

Batista CEMM. Assessment of neuropathic pain and motor and somatosensory functions after stem cell transplantation in rat spinal cord injury model [thesis]. São Paulo: "Faculdade de Medicina, Universidade de São Paulo"; 2018.

Neuropathic pain after spinal cord injury (SCI) is a complex condition which responds poorly to usual treatments. Cell transplantation represents a promising therapy; nevertheless, the ideal cell type in terms of neurogenic potential and effectiveness against pain remains largely controversial. Thus, the objective of the present study was to evaluate the ability of fetal neural stem cells (fNSC) to relieve chronic pain and, secondarily, to evaluate the effects on motor recovery. For this purpose, a pilot was initially designed to define the best animal model; accordingly, Wistar rats were submitted to traumatic spinal cord injury of mild or moderate intensity (pendulum height $12.5 \mathrm{~mm}$ and $25 \mathrm{~mm}$, respectively) using the NYU Impactor. The results indicated that spinal cord injury of moderate intensity is a good model for the study of central neuropathic pain, because in addition to a motor function deficit and painful sensation more pronounced than the animals submitted to mild injury, the animals remained stable throughout the study. Additionally, sensitive deficits were observed from the first days after the injury and lasted eight weeks, enabling the objective of the work. Based on the pilot result, Wistar rats were submitted to moderate spinal cord injury; seven days after spinal cord injury, immunosuppression with cyclosporine was initiated; ten days after injury the animals received intra-spinal injections of culture medium (sham group) or fNSC extracted from the telencephalic vesicles (TV group) or from the ventral medulla (VM group) of E14 embryos of the same species. Behavioral and pain assessment were performed weekly during eight weeks. Thereafter, spinal cords were processed for immunofluorescence, and transplanted fetal cells were quantified by stereology. The results showed improvement of thermal hyperalgesia in TV group after the fifth week of transplantation $(p<0.001)$ and in VM group after the fourth week $(p<0.001)$. Moreover, mechanical allodynia improved in both TV and VM groups at the 8th week (TV $p<0.05$ and VM $p<0.01$ compared to sham). No significant motor recovery was observed in TV and VM groups when compared to sham group. Stereological analyses showed that $\sim 70 \%$ of TV and VM cells differentiated into NeuN+ neurons, with high proportion of enkephalinergic and GABAergic cells in the TV group (44\% and $42 \%$, respectively) and enkephalinergic and Serotoninergic cells in the VM group (50\% and $47 \%$, respectively). Our study suggests that neuronal precursors from the TV and VM, once implanted into the injured spinal cord, maturate into different neuronal subtypes, mainly GABAergic, serotoninergic, and enkephalinergic, and both precursors were able to alleviate pain, despite no significant motor recovery.

Descriptors: spinal cord injuries; hyperalgesia; fetal stem cells; cell transplantation; cell differentiation; nerve regeneration; rats, Wistar. 
INTRODUÇÃO 


\section{INTRODUÇÃO}

\subsection{Lesão Medular}

A lesão da medula espinal é uma síndrome neurológica devastadora, com grande repercussão física, psíquica e social. A prevalência mundial dessa condição é de 10,5 casos a cada 100.000 habitantes; adicionalmente, cerca de 768 novos casos ocorrem por ano, acometendo principalmente homens entre $30 \mathrm{e}$ 40 anos de idade (Kumar et al., 2018). Os acidentes automobilísticos correspondem à principal causa de lesão medular (38\%), seguido por quedas (32\%), violência (14\%), esportes (8\%) e outros (8\%) (NSCISC, 2018).

O primeiro registro documentado de lesão medular foi encontrado em um papiro descoberto por Edwin Smith em 1862 na antiga cidade de Tebas/Egito, o qual foi traduzido posteriormente pelo egiptólogo James Breasted (Breasted, 1930). A escrita hieroglífica deste papiro permite datá-lo como do século XVII a.C.; no entanto, acredita-se que o texto original tenha sido escrito durante 0 Antigo Império, cerca de 2.500-3.000 a.C.. O texto é um tratado sobre cirurgia do trauma e contém a descrição de 48 casos, todos incluindo exames, diagnóstico e tratamento. Um dos casos mais interessantes do papiro é o caso 31 , o qual contém instruções acerca do deslocamento de uma vértebra cervical: "Se você examinar um homem que tem um deslocamento na vértebra de seu pescoço, você deve encontrá-lo inconsciente de seus dois braços (e) suas duas pernas por causa disso, enquanto seu falo é erguido por causa disso, (e) a urina cai de seu membro sem que ele saiba..." (Changeux, 1985; Hughes, 1988). De acordo com seu diagnóstico, esta não é uma doença a ser tratada, tornando-se evidente que, 
desde aquela época, a lesão medular era uma doença perturbadora e de difícil tratamento. Esse preceito persistiu até o final do século XIX, quando os primeiros experimentos em animais começaram a surgir na tentativa de compreender os eventos fisiopatológicos envolvidos após a lesão da medula espinal, possibilitando o desenvolvimento de novas terapias.

A lesão medular resulta em alterações motoras e sensitivas abaixo do nível da lesão, promovendo problemas irreversíveis ou de recuperação variável conforme o dano causado no tecido nervoso (Guan, 2012). Referida lesão pode ser caracterizada em fase primária e secundária. A lesão primária é o resultado das forças físicas durante o evento traumático inicial, elas podem incluir compressão, cisalhamento, laceração e alongamento agudo e geralmente representam o fator mais determinante da gravidade da lesão (Ackery et al., 2004; Rowland et al., 2008). Apesar dos danos causados pela lesão primária, os mecanismos fisiopatológicos envolvidos na fase secundária são capazes de expandir a zona de lesão e exacerbar os desfechos e déficits neurológicos finais (Yip e Malaspina, 2012). A lesão secundária é uma lesão tissular retardada e progressiva após o trauma inicial e pode ser dividida em fase imediata, aguda, intermediária e crônica, de acordo com o período pós-lesão e as mudanças fisiopatológicas (figura 1).

Fase imediata: corresponde aos resultados imediatos do evento traumático e dura, aproximadamente, duas horas. Nesta fase ocorre a morte rápida de neurônios e células da glia, acompanhado de choque medular, com consequente perda da função motora e sensitiva abaixo do nível da lesão (Ditunno et al., 2004; Norenberg et al., 2004). A primeira mudança patológica 
detectável após a lesão é um inchaço generalizado da medula espinal, acompanhado muitas vezes de hemorragia na substância cinzenta central, que resulta na morte necrótica imediata das células devido à ruptura mecânica direta das membranas celulares ou isquemia causada pela ruptura vascular. A ruptura da microvasculatura também leva a hemorragia, em grande parte petequial, na substância branca circundante (Tator e Koyanagi, 1997; Kakulas, 2004). A combinação do inchaço e da hemorragia produz isquemia na medula espinal, a qual pode se estender por vários segmentos, tanto rostral quanto caudal. Outros processos fisiopatológicos também são iniciados nessa fase, por exemplo, a ativação de células microgliais começa quase instantaneamente após a lesão, com a regulação positiva das citocinas pró-inflamatórias TNFa e IL- $\beta$ (Pineau e Lacroix, 2007; Donnelly e Popovich, 2008). Ademais, níveis de glutamato extracelular podem atingir níveis excitotóxicos dentro de minutos após a lesão, culminando com influxo de $\mathrm{Ca}^{2+}$ por canais NMDA (N-metil-D-aspartato) e morte por apoptose (Park et al., 2004; Carlson et al., 2010; Gerardo-Nava et al., 2013).

Fase aguda: essa fase representa 0 período onde os processos secundários de lesão tornam-se mais dominantes. Ela pode ser subdividida em fase aguda precoce e subaguda.

Fase aguda precoce: pode durar de 2 a 48 horas após a lesão medular. Ela é caracterizada pela continuidade da hemorragia, aumento do edema e inflamação e marca o início de processos de lesões secundárias adicionais, incluindo a produção de radicais livres, desregulação iônica e excitotoxicidade mediada por glutamato, que contribuem para morte celular. 
A isquemia e a infiltração celular imunitária podem levar à produção de estresse oxidativo e de radicais livres. As espécies reativas de oxigênio (ERO) e de nitrogênio (ERN) podem ser produzidas por macrófagos/microglia após a lesão medular, ou mesmo serem liberadas como resultado da isquemia e reperfusão (Sakamoto et al., 1991; Chatzipanteli et al., 2002). Os níveis de ERO atingem seu pico 12 horas após a lesão e permanecem elevados por 1 semana, voltando aos níveis basais após 4 - 5 semanas do início da lesão (Donnelly e Popovich, 2008). Nessa fase, torna-se imprescindível aliviar possíveis compressões sobre o parênquima medular, a fim de se evitar a perpetuação da isquemia (descompressões cirúrgicas e/ou estabilizações vertebrais), além de se adotar medidas intervencionistas para se garantir maior perfusão sanguínea ao parênquima medular lesado.

Adicionalmente, essa fase envolve a ativação contínua das micróglias residentes, resultando na liberação acentuada de quimiocinas e citocinas e na infiltração de células inflamatórias (Donnelly e Popovich, 2008; Tzekou e Fehlings, 2014). O aumento da permeabilidade da barreira hematoencefálica (BHE) permite a infiltração de células do sistema imune para o sistema nervoso central (SNC), tais como linfócito $T$, neutrófilos e monócitos. Este efeito alcança o seu pico 2 horas após a lesão, com retorno a níveis fisiológicos 2 semanas depois do trauma (Figley et al., 2014). Embora o aumento inicial da permeabilidade seja em grande parte devido ao rompimento mecânico direto de células endoteliais e processos astrocíticos que compõem a BHE, um número de mediadores inflamatórios envolvidos na fase secundária exercem um efeito intenso na permeabilidade dessa barreira. Um exemplo são as citocinas pró-inflamatórias TNFa e IL-1 $\beta$, que 
estão hiperreguladas após a lesão medular e são capazes de aumentar a permeabilidade vascular (Schnell et al., 1999; Pineau e Lacroix, 2007). No entanto, outros compostos liberados por células gliais ou células imunes invasoras também podem desempenhar um papel no aumento da permeabilidade da BHE, tais como ROS, óxido nítrico, histamina, metaloproteinases de matriz e elastase (Donnelly e Popovich, 2008).

Por sua vez, a desregulação iônica e a excitotoxicidade seguem imediatamente após a lesão medular e contribuem para o dano e perda celular. Os níveis extracelulares de glutamato aumentam após a lesão como consequência da ruptura dos transportadores de membrana que mantêm a homeostase iônica e do glutamato (Llado et al., 2004). Isso resulta na ativação excessiva dos receptores glutamatérgicos, levando a um influxo aumentado de íons sódio e cálcio através dos receptores NMDA e AMPA (alfa-amino-3-hidroximetil-5-4-isoxazolpropiónico), desregulação da atividade metabólica e mitocondrial e perda do equilíbrio osmótico, que resulta em morte celular excitotóxica (Park et al., 2004; Gerardo-Nava et al., 2013).

Os processos descritos durante essa fase tem como consequência a morte celular e a desmielinização. Grande parte da morte neuronal ocorre por meio de necrose (embora a apoptose também tenha um papel importante), em contrapartida, a morte celular de oligodendrócitos ocorre principalmente por apoptose e é parcialmente dependente da ativação do receptor Fas e da sinalização via receptor p75 (Keane et al., 2001; Beattie et al., 2002; Yu et al., 2009). 
Fase subaguda: dura aproximadamente de 2 dias a 2 semanas após a lesão medular. A resposta fagocitária atinge seu ápice durante esse período, removendo detritos celulares da área de lesão (Donnelly e Popovich, 2008). Os astrócitos, findada a etapa necrótica da fase aguda, tornam-se hipertróficos e proliferativos na fase subaguda, iniciando a formação da cicatriz glial, que representa uma barreira tanto física quanto química à regeneração (Fawcett e Asher, 1999; Hagg e Oudega, 2006; Karimi-Abdolrezaee et al., 2010). Por outro lado, os astrócitos também possuem funções benéficas após a lesão medular, como a promoção do restabelecimento da homeostase iônica e da integridade da BHE, que é importante para a resolução do edema e limitação da infiltração de células imunes (Herrmann et al., 2008).

Fase intermediária: essa fase inicia entre a $2^{\mathrm{a}}$ e a $3^{\mathrm{a}}$ semana e continua até o 6ํำ mêsós a lesão, sendo caracterizada pela maturação da cicatriz glial (Siddiqui et al., 2015). A cicatriz glial é responsável pela escassez da neurorregeneração devido à ausência de substrato celular e fatores apropriados que suportem o crescimento axonal, bem como pela produção de moléculas inibitórias ao crescimento axonal, como as proteoglicanas de sulfato de condroitina (CSPGs) (Lemons et al., 1999; Bradbury et al., 2002; Jones et al., 2003). Além dos astrócitos, a mielina do SNC também produz a glicoproteína associada à mielina (MAG), Nogo-A e a glicoproteína da mielina de oligodendrócito (MOG), que são capazes de inibir o crescimento axonal (Wang et al., 2002; Schweigreiter e Bandtlow, 2006).

Fase crônica: essa fase inicia após o $6^{\circ}$ mês de lesão e continua ao longo da vida do paciente. Ela é caracterizada pela maturação/estabilização da lesão. 
Nessa fase a cicatriz glial e os cistos/siringes na medula espinal já estão desenvolvidos e estabelecidos. Por sua vez, a degeneração walleriana (retração axonal) continua e pode levar anos até que os corpos celulares e os restos de axônios degenerados sejam totalmente removidos do sítio da lesão (Basso et al., 1996; Beattie et al., 2002; Ehlers, 2004; Norenberg et al., 2004; Fleming et al., 2006; Kramer et al., 2013). Apesar do relato de alguns casos onde foi observado uma melhora da função neurológica muitos anos após a lesão (McDonald et al., 2002), é considerado que após 1-2 anos de lesão os déficis neurológicos tenham se estabilizados e a lesão amadurecida completamente (Rowland et al., 2008). A lesão, infelizmente, pode não permanecer estática e a formação de siringomielia, em aproximadamente $30 \%$ dos pacientes com lesão medular, pode causar disfunção neurológica tardia bem como dor neuropática (Stoodley, 2000).

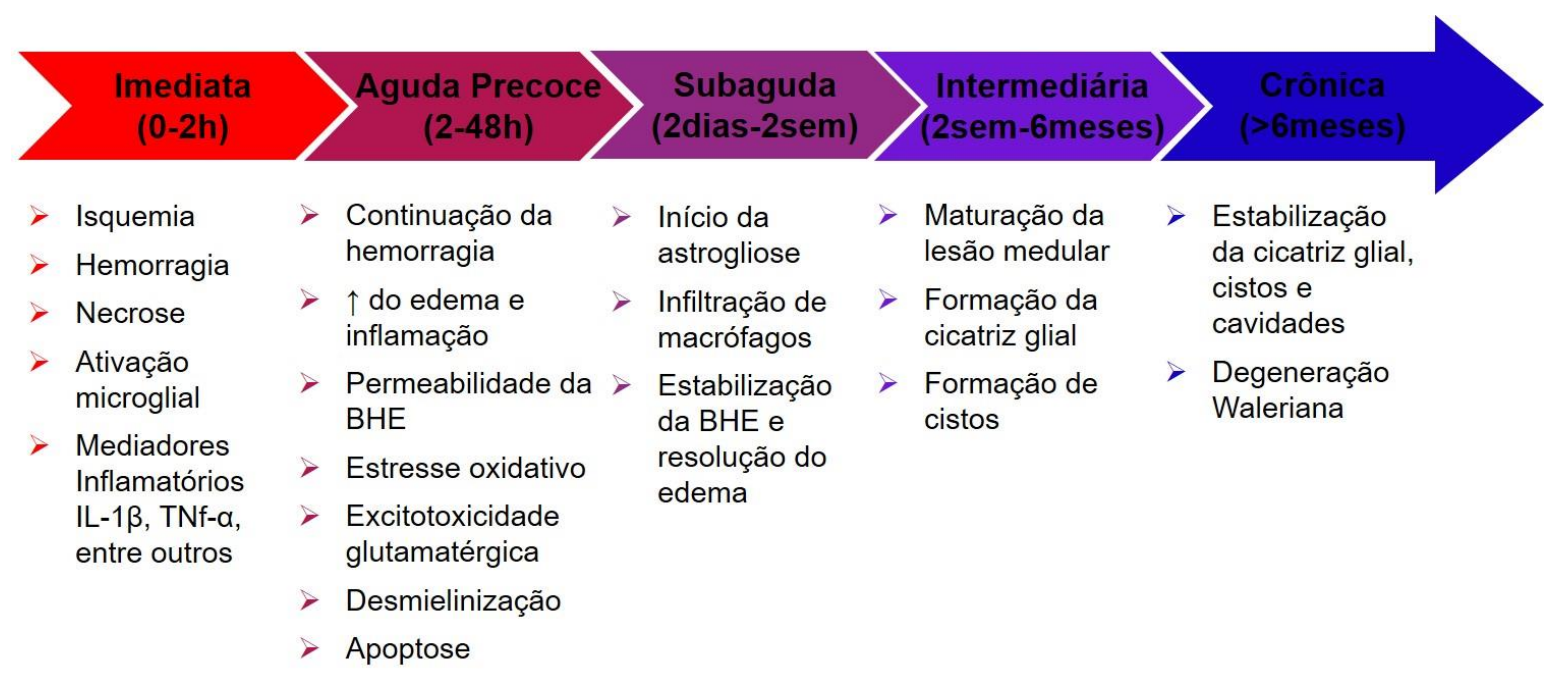

FONTE: Desenvolvido pela autora, 2018.

Figura 1: Fases da lesão medular e principais eventos fisiopatológicos. Os eventos secundários estão divididos em fase imediata (até 2 horas), aguda precoce (2 a 48 horas), subaguda ( 2 dias a 2 semanas), intermediária ( 2 semanas a 6 meses) e crônica (a partir de 6 meses). 


\subsection{Alterações Associadas à Lesão Medular}

\subsubsection{Comprometimento Sensório Motor}

A desconexão dos tratos e feixes de fibras nervosas responsáveis pela comunicação ascendente e descendente da medula espinal resulta em alterações sensório motoras nos segmentos do corpo localizados abaixo da lesão. Dependendo do nível medular acometido, a lesão pode resultar em uma tetraplegia ou paraplegia. A tetraplegia ocorre após uma lesão na medula cervical, resultando na paralisia parcial ou completa dos quatro membros e tronco, incluindo os músculos respiratórios. Por sua vez, a paraplegia é ocasionada por uma lesão no segmento medular torácico, lombar ou sacral e têm como consequência à paralisia parcial ou completa dos membros inferiores e parte do tronco (Lundy-Ekman, 2008).

As lesões medulares podem ser classificadas de acordo com o tipo de lesão (completa ou incompleta) e o nível neurológico. A lesão completa é caracterizada pela ausência da função sensorial e motora no segmento sacral, enquanto na lesão incompleta há preservação da função sensorial e/ou motora no segmento sacral. O nível neurológico da lesão é determinado pelo segmento mais caudal com função motora e sensorial preservada bilateralmente. No entanto, a função motora pode estar comprometida em um nível diferente da sensorial, resultando em assimetrias. Nesses casos, até quatro segmentos neurológicos podem ser descritos em um único paciente: sensorial direito, sensorial esquerdo, motor direito e motor esquerdo (Wentz de Moura et al., 2009). 
De acordo com a escala estabelecida pela "American Spinal Injury Association" (ASIA, 2002), é possível classificar o paciente em uma das cinco categorias descritas, de acordo com o resultado do exame dos componentes sensitivo e motor. Segue abaixo a classificação:

- ASIA A (completa): nenhuma função sensorial ou motora nos segmentos sacrais S4-S5.

- ASIA B (incompleta): nenhuma função motora, porém alguma função sensorial é preservada abaixo do nível neurológico incluindo os segmentos sacrais S4-S5.

- ASIA C (incompleta): função motora preservada abaixo do nível neurológico e mais da metade dos músculos chave abaixo do nível neurológico têm grau de força muscular abaixo de 3 (apesar de haver contração muscular, não são capazes de vencer a gravidade).

- ASIA D (incompleta): função motora preservada abaixo do nível neurológico e pelo menos metade dos músculos chave abaixo do nível neurológico tem grau de força muscular maior ou igual a 3 (vencem a gravidade).

- ASIA E (normal): funções motoras e sensitivas normais.

\subsubsection{Disfunções Autonômicas}

A medula espinal é responsável pela transmissão e modulação de diversas informações e funções decorrentes do sistema nervoso autônomo (SNA) (Krassioukov et al., 2007; McCorry, 2007). Após a lesão medular, o comprometimento das vias autonômicas (medulares) pode resultar em alterações 
da regulação homeostática e de funções vitais, mediadas pelo SNA, com manifestações clínicas diversificadas e potencialmente graves (Krassioukov et al., 2007; McCorry, 2007). Entre as manifestações causadas pela disfunção do SNA após lesão medular podem ser citadas:

Choque Neurogênico: é caracterizado pela tríade de hipotensão, bradicardia e hipotermia, provavelmente devido a um desequilíbrio no controle autonômico, com uma influência parassimpática intacta via nervo vago e uma perda do tônus simpático por conta de uma interrupção do controle supraespinal (Krassioukov et al., 2007). Além do choque neurogênico, a fase aguda da lesão medular também é associada com o choque medular. Apesar de alguns autores usarem estes termos de forma intercambiável, é importante reconhecer que o choque neurogênico e o medular são duas situações clínicas distintas. O choque neurogênico resulta de uma disfunção autonômica com repercussões vasomotoras e cardíacas, enquanto o choque medular se caracteriza por uma perda ou depressão transitória sensorial, motora e reflexa abaixo do nível da lesão, causado possivelmente por uma súbita e abrupta interrupção de todas as influências excitatórias descendentes (Ditunno et al., 2004; Krassioukov e Claydon, 2006).

Disfunções Cardiovasculares: o SNA regula diversos parâmetros da função cardiovascular, tais como o fluxo coronário, a contractilidade e frequência cardíaca e respostas vasomotoras periféricas. Após uma lesão da medula espinal, o compromisso da atividade autonômica está diretamente relacionado com o nível e a gravidade da lesão (Krassioukov et al., 2007; Grigorean et al., 2009). Nas lesões acima de T6, o comprometimento da inervação cardíaca simpática, 
juntamente com a integridade da inervação parassimpática via nervo vago, originam quadros de desregulação e disfunção cardíaca (ex. bradicardia) por preponderância vagal (Krassioukov et al., 2007; Grigorean et al., 2009; Popa et al., 2010). Outro quadro comumente observado é a hipotensão ortostática (HO), que é caracterizada por uma redução extrema na pressão arterial ao assumir a posição ereta. Os episódios de $\mathrm{HO}$ podem ser assintomático ou acompanhados de tonturas/ vertigens, cefaleias, fadiga, hipersudorese, náusea, palidez e lipotimia (Teasell et al., 2000; Popa et al., 2010), e diversos mecanismos fisiopatológicos podem estar envolvidos, tais como: disfunção do sistema nervoso simpático, baixos níveis de catecolaminas, disfunção dos barorreceptores carotídeos e aórticos, secreção inapropriada do hormônio antidiurético, descondicionamento cardiovascular e déficit motor (perda da bomba muscular esquelética) (Soni et al., 1994; Laszlo et al., 2001; Chao e Cheing, 2005; Claydon e Krassioukov, 2006; Krassioukov e Claydon, 2006; Popa et al., 2010).

Disfunções Vesicais: a disfunção da bexiga após a lesão medular pode ser classificada em síndrome do motoneurônio inferior (MNI) ou superior (MNS). $\mathrm{Na}$ síndrome do MNI, a lesão na região sacral resulta em um comprometimento dos sinais motores eferentes da bexiga e diminuição ou ausência da contratilidade do detrusor, resultando em flacidez. Por outro lado, a síndrome do MNS (mais frequente entre os indivíduos com lesão medular) é caracterizada pela interrupção das vias descendentes da medula espinal que influenciam ou modificam o centro de micção sacral, causando uma perda da inibição cortical dos arcos reflexos sacrais. Uma lesão completa acima do nível sacral geralmente possibilita algum funcionamento reflexo dos órgãos pélvicos, porém não é possível o controle 
voluntário e a percepção consciente do estado desses órgãos (Gomelsky et al., ; Hamid et al., ; Burns et al., 2001).

Função Sexual: a disfunção erétil em homens após a lesão medular tem características diferentes dependendo do nível da lesão e segue principalmente o padrão de disfunção da bexiga. Um indivíduo com lesão do MNS geralmente têm a capacidade de ereção reflexa por estimulação tátil, por outro lado, uma lesão do MNI resulta em uma perda de toda função erétil. Ainda, a capacidade de ereção psicogênica é perdida quando a lesão medular é completa. No caso das mulheres, a função sexual também é prejudicada e é recomendado tratamento para perda da lubrificação. A fertilidade nas mulheres não é afetada, no entanto, distúrbios autonômicos podem aumentar os riscos de incontinência urinária, infecção do trato urinário, úlceras de pressão, bem como a possibilidade de desenvolver disreflexia autonômica grave durante o trabalho de parto (Karlsson, 2006; Krassioukov e Elliott, 2017).

Disreflexia autonômica: é uma resposta excessiva do sistema nervoso simpático evocada por estímulos, nocivos ou não, abaixo do nível da lesão. Geralmente ocorre em lesões acima do nível T6. Diversos estímulos podem desencadear essa síndrome, incluindo a distensão da bexiga e do intestino, lesões ou fraturas, infecção urinária, entre outros. Os sintomas mais comuns são cefaleia, bradicardia, manchas vermelhas na pele, aumento da pressão arterial e sudorese. A disreflexia autonômica pode se tornar crônica em resposta a outro problema crônico, como distúrbios urinários e úlceras de pressão, ou ainda resultar em complicações mais graves, como hemorragia cerebral, edema 
pulmonar, infarto do miocárdio e morte (Karlsson, 1999; Krassioukov et al., 2007; Lundy-Ekman, 2008).

Disfunção térmica: a temperatura corporal encontra-se sob o controle autonômico direto via regulação hipotalâmica. Os termorreceptores periféricos enviam informações até o hipotálamo através da medula espinal, dessa forma, quando há uma diminuição da temperatura corporal, são ativados os mecanismos simpáticos que induzem piloereção, tremor e vasoconstrição periférica e cutânea para produção de calor e redirecionamento da circulação para os órgãos centrais e quando ocorre um aumento da temperatura corpórea ocorre a sudação, vasodilatação cutânea e, consequentemente, o arrefecimento. A perda de informação ao hipotálamo após a lesão medular pode condicionar toda ativação simpática e resultar em uma termorregulação deficiente. Nas lesões medulares acima de T6, mais da metade do corpo perde o controle descendente hipotalâmico-simpático, resultando em uma disfunção térmica grave com variação da temperatura central (são considerados poiquilotérmicos). Nos níveis de lesão abaixo de T6, a disfunção térmica pode ser ligeira ou moderada e nem sempre há variação significativa da temperatura central (Schmidt e Chan, 1992; Colachis e Otis, 1995; Stocks et al., 2004; Garstang e Miller-Smith, 2007).

\subsubsection{Espasticidade}

A espasticidade é uma complicação frequente após a lesão medular, presente em cerca de $70 \%$ dos indivíduos, podendo contribuir para um comprometimento funcional adicional (Andresen et al., 2016; Holtz et al., 2017). 
De acordo com sua definição clássica, a espasticidade é uma desordem motora caracterizada pelo aumento, velocidade dependente, do tônus muscular, com exacerbação dos reflexos profundos, decorrente de hipersensibilidade do reflexo de estiramento (Lance, 1990). A patogênese da espasticidade em pacientes com lesão medular é multifatorial e envolve uma complexa cadeia de alterações em várias redes interdependentes. Os mecanismos propostos envolvem desinibição por perda de vias descendentes e/ou interneurônios, hiperexcitabilidade neuronal, potencial de ação ectópico, brotamento axonal, regulação positiva de receptores, efeitos de desaferentação nos neurônios rostrais ou caudais, ativação da glia e neuroinflamação (Nielsen et al., 2007; Corleto et al., 2015).

A espasticidade tem o potencial de influenciar negativamente a qualidade de vida dos pacientes, restringindo as atividades diárias, inibindo o andar efetivo e auto cuidado, causando dor, fadiga, distúrbios do sono, contribuindo para o desenvolvimento de contraturas, úlceras de pressão, infecção, autoimagem negativa, complicações relacionadas ao cateter e impedindo uma reabilitação adequada (Parziale et al., 1993; Kirshblum, 1999; Skold et al., 1999; Jozefczyk, 2002).

A espasticidade compartilha muitas características da dor neuropática central (para mais detalhes sobre dor neuropática vide as próximas secções). Após a lesão medular, a neuroplasticidade, que envolve respostas neuronais, estruturais e funcionais, é essencial para a recuperação da função neurológica, no entanto, o lado escuro desse processo pode ser o desenvolvimento da espasticidade e da dor neuropática (Brown e Weaver, 2012). Ambas as condições 
podem ter um início tardio após a lesão medular e se desenvolver lentamente ao longo do tempo e, uma vez desenvolvidas, tornam-se frequentemente crônicas. Ademais, tanto a espasticidade quanto a dor neuropática podem ser provocadas pelo toque e outros estímulos não dolorosos (Sjolund, 2002).

Diferentes subtipos de dor podem estar relacionados com a espasticidade, no entanto, é difícil examinar possíveis relações com a dor neuropática devido à dificuldade em distinguir a dor neuropática da dor musculoesquelética, que é um resultado muito comum de espasticidade (Shaikh et al., 2016).

\subsubsection{Dor Após Lesão Medular}

A lesão medular é uma das principais causas de comprometimento físico a longo prazo, no entanto, além do déficit motor, a dor é considerada uma das complicações mais incapacitantes e vivenciadas entre os indivíduos vitimizados pela lesão medular. Como já diziam os romanos, "dolor dictat", ou seja, a dor dita, domina e comanda.

Segundo a IASP (International Association for the Study of Pain), a dor é "uma experiência emocional e sensorial desagradável associada com uma lesão tecidual real ou potencial, ou descrita em termos de tal lesão", sendo que cada indivíduo aprende a utilizar esse termo de acordo com suas experiências anteriores (Loeser e Treede, 2008). Cerca de 94\% dos pacientes apresentam algum tipo de dor após a lesão medular e $70 \%$ dos casos evoluem para dor crônica (Teixeira et al., 2013). A dor após lesão da medula espinal pode ser dividida em dor nociceptiva (musculoesquelética ou visceral) e neuropática (acima do nível, no nível ou abaixo do nível de lesão, tabela 1) (Siddall et al., 2003). 
Tabela 1: Classificação da dor após lesão medular

\begin{tabular}{|c|c|c|}
\hline Tipo de Dor & Localização & Características \\
\hline \multirow[b]{2}{*}{ Nociceptiva } & Visceral & $\begin{array}{l}\text { Cálculos renais, disfunções esfincterianas, intestino } \\
\text { e cefaléia disreflexa }\end{array}$ \\
\hline & Musculoesquelética & $\begin{array}{c}\text { Ossos, articulações, trauma ou inflamação } \\
\text { muscular, instabilidade mecânica, espasmos } \\
\text { musculares }\end{array}$ \\
\hline \multirow{3}{*}{ Neuropática } & Acima do Nível & Localizada em regiões de sensibilidade preservada \\
\hline & No Nível & Localizada na faixa do nível da lesão \\
\hline & Abaixo do Nível & Localizada difusamente abaixo do nível da lesão \\
\hline
\end{tabular}

\subsubsection{Dor Neuropática}

De acordo com a IASP, a dor neuropática é definida como "uma dor iniciada ou causada por lesão primária ou disfunção do sistema nervoso somatossensorial" (Merskey, 2014). Ela pode ser apresentada de forma espontânea ou evocada e está frequentemente associada à alodínia, hiperalgesia e hiperpatia (Finnerup et al., 2001). Além disso, a dor neuropática após a lesão medular é comumente descrita pelos pacientes como uma sensação de queimação, esfaqueamento, tiro ou choque (Kramer et al., 2017).

A principal causa de dor neuropática após a lesão medular é a hiperexcitabilidade de neurônios de segunda ordem (WRN/ wide range neurons) localizados no corno dorsal da medula espinal, que resulta no aumento da percepção dolorosa por estruturas supraespinais, como o tálamo, em resposta do desequilíbrio da atividade das vias ascendentes e descentes (inibitórias) da dor (Basbaum et al., 2009; Costigan et al., 2009; Rekand et al., 2012). Entre os mecanismos envolvidos podemos citar a plasticidade estrutural (por exemplo, remodelação da espinha dendrítica, brotamento dendrítico e neo-sinaptogênese) (Tan et al., 2008; Zhao et al., 2016), desregulação da liberação, captação e 
expressão do receptor de glutamato (Leem et al., 2010; Putatunda et al., 2014; Falnikar et al., 2016), perda do tônus inibitório local (GABAérgico) (Drew et al., 2004; Meisner et al., 2010), disfunções das vias moduladoras descendentes (especialmente serotoninérgicas), aumento da expressão do canal de cálcio (Boroujerdi et al., 2011), entre outros.

A sensibilização central é uma das caracteristica marcante da dor neuropática e é responsável por muitas das alterações temporais, espaciais e limiares da sensibilidade à dor. Ela é mantida em resposta a liberação de diversos neurotransmissores no corno dorsal da medula espinal, como por exemplo o glutamato, a substância $\mathrm{P}$ e o peptídeo relacionado ao gene da calcitonina, os quais se ligam aos seus respectivos receptores e causam a ativação de cascatas de sinalização intracelulares, incluindo a ativação da proteína quinase $\mathrm{C}$, proteínas quinases ativadas por mitógenos e fatores de transcrição, que irão contribuir para a manutenção do quadro de excitabilidade neuronal (Latremoliere e Woolf, 2009; Woolf, 2011). Ademais, células inflamatórias infiltrantes, tais como macrófagos, mastócitos e neutrófilos, migram para o local de lesão e liberam mediadores que se ligam a receptores específicos presentes nos neurônios sensoriais, resultando na sensibilização dessas fibras e provocando um aumento na sua responsividade aos estímulos mecânicos e térmicos (Gold e Gebhart, 2010). As células da glia, por sua vez, são uma importante fonte de citocinas inflamatórias e, ao que tudo indica, a microglia tem um papel fundamental para o desenvolvimento da dor neuropática, enquanto que os astrócitos são 
mais importantes para a manutenção desta condição (Raghavendra et al., 2003; Cunha e Dias, 2009).

A dor neuropática está presente em cerca de $40-50 \%$ dos pacientes lesados medulares e geralmente se desenvolve no primeiro ano após a lesão (Finnerup, 2013). Embora diversas drogas tenham sido usadas para tratar a dor neuropática após lesão medular (por exemplo, antidepressivos, antiepilépticos e analgésicos), as abordagens farmacológicas geralmente resultam em uma redução de apenas 20-30\% na intensidade da dor (Baastrup e Finnerup, 2008). Assim, novas estratégias para o tratamento da dor neuropática são necessárias para melhorar o prognóstico e a qualidade de vida desses pacientes.

\subsection{Abordagens Terapêuticas}

Visto a natureza complexa dos eventos que se seguem à lesão da medula espinal, muitas alternativas têm sido propostas na tentativa de reparo dessa região. Estratégias clínicas atuais incluem a cirurgia precoce, a descompressão cirúrgica da medula espinal, o controle rigoroso da pressão arterial e o tratamento com esteroides (ex. a metilprednisolona), que tem como objetivo principal a redução da lesão secundária logo após o trauma primário ter ocorrido (Carlson et al., 1997; Bracken, 2012; Batchelor et al., 2013; Saadeh et al., 2017). Não obstante, outras alternativas têm sido fortemente pesquisadas e muitas já se encontram em fase de ensaio clínico. Esses novos tratamentos podem ter uma abordagem farmacológica (ex. anti-Nogo-A, fator de crescimento de fibroblastos, minociclina, riluzol, gaciclidina e cetrina), fisiológica (ex. hipotermia terapêutica, drenagem do fluido cerebrospinal e hipóxia intermitente aguda), de intervenção 
funcional e reabilitação (ex. estimulação da medula espinal, estimulação transcraniana, exoesqueleto e treino locomotor), utilizando biomateriais (scaffolds) ou transplantando células (revisado em Donovan e Kirshblum, 2018).

As técnicas de transplante celular têm se mostrado uma estratégia promissora e podem ser utilizadas com o objetivo de minimizar a lesão e promover a recuperação do tecido lesado (Eftekharpour et al., 2008). Entre as candidatas, podemos citar as células de Schwann, as células da glia do nervo olfatório (olfactory ensheathing cells - OECs) e as células tronco. As células de Schwann e as OECs são consideradas provedoras de suporte neurotrófico, substrato propício para o crescimento celular, e de remielinização para axônios poupados pela injúria (Kwon e Tetzlaff, 2001). Por sua vez, as células tronco podem promover a regeneração do sistema nervoso lesionado, representando, desta forma, uma nova perspectiva terapêutica para além das poucas opções que existiam até hoje.

\subsubsection{Células Tronco e Terapia Celular}

Pesquisas acerca da biologia das células tronco têm crescido exponencialmente nos últimos anos, compreendendo aspectos básicos e aplicados que variam desde o nível celular até o tecidual. O desenvolvimento e a organização das células tronco é um processo dinâmico e funcional e suas características peculiares, descritas abaixo, tornam essas células únicas e com grande potencial para fins terapêuticos.

As células tronco são células imaturas com grande capacidade de autorrenovação e diferenciação. A autorrenovação é a extensa capacidade 
proliferativa através da divisão celular assimétrica, ou seja, com manutenção do nicho de células indiferenciadas e outro nicho de células que adentrarão o processo de diferenciação; o potencial de diferenciação define a capacidade das células tronco de se diferenciarem em diversos tipos de células maduras e especializadas. As células tronco podem ser encontradas em todos os organismos multicelulares e são responsáveis pelo crescimento, reparo e homeostase de vários tecidos (Hosseinkhani et al., 2013; Batista et al., 2014).

De acordo com a sua origem, as células tronco podem ser classificadas em três grupos: células tronco embrionárias, células tronco fetais e células tronco adultas. Em relação ao seu grau de plasticidade, isto é, o potencial para se diferenciarem em vários tipos de células ou tecidos, as células tronco podem ser separadas nos seguintes grupos: totipotentes, pluripotentes e multipotentes (Bongso e Richards, 2004).

Células tronco totipotentes: são as células mais indiferenciadas encontradas no embrião nas primeiras fases de divisão. São consideradas células totipotentes o ovo fertilizado (zigoto) e suas primeiras células descendentes, até que a mórula atinja o estágio de 16 células (cerca de 3 dias). Essas células são capazes de gerar um novo organismo completo, incluindo os tecidos embrionários e extraembrionários que formarão o embrião e a placenta (Surani e Tischler, 2012).

Células tronco pluripotentes: $O$ maior exemplo de células tronco pluripotentes são as células extraídas da massa interna do blastocisto (embrião com 5-6 dias de vida), chamadas de células tronco embrionárias. Essas células 
são capazes de se diferenciarem em todos os tecidos humanos, excluindo a placenta e os anexos embrionários (Polejaeva e Mitalipov, 2013).

Células tronco multipotentes: essas células são um pouco mais diferenciadas e por isso possuem um repertório mais restrito em relação a sua capacidade de diferenciação, o qual geralmente está associado ao tecido/órgão onde se encontram. Elas estão presentes durante a vida embrionária e, em alguns tecidos, permanecem no organismo adulto, participando no reparo e regeneração tecidual. As células tronco multipotentes podem ser obtidas de várias regiões, um exemplo são as células tronco mesenquimais extraídas da medula óssea e do sangue do cordão umbilical (Battiwalla e Hematti, 2009; Ratajczak et al., 2012; Wislet-Gendebien et al., 2012).

Outro tipo de célula tronco intensamente investigada nos últimos tempos são as células tronco pluripotentes induzidas, também conhecidas como iPS ou iPSC (do inglês induced pluripotent stem cells). A técnica visa gerar células pluripotentes através da reprogramação de fibroblastos, ou qualquer outro tipo celular, e foi desenvolvida pelos pesquisadores japoneses Kazutoshi Takahashi e Shinya Yamanaka (Takahashi e Yamanaka, 2006; Takahashi et al., 2007). processo de reprogramação ocorre através da inserção de um vírus contendo quatro genes (OCT4, KLF-4, SOX-2, e C-MYC). Estes genes se inserem no DNA da célula adulta, como por ex. uma célula da pele, e reprogramam o código genético. Com este novo programa, as células se tornam muito similares às células tronco embrionárias, apresentando as mesmas características de autorrenovação e potencial de diferenciação. 
Cada tipo de célula tronco apresenta vantagens e desvantagens e conhecer o perfil de cada uma é essencial para que o transplante seja efetivo. Por exemplo, as células tronco embrionárias são pluripotentes e, devido a sua capacidade de gerar quase todas as células de um organismo, possuem um grande potencial para restaurar lesões do cérebro e da medula espinal. No entanto, essas células podem ser rejeitadas pelo sistema imunológico do paciente (faz-se necessário à imunossupressão), existe a possibilidade de formação de tumores e, ainda, existem preocupações éticas em relação ao uso de embriões humanos (Aleynik et al., 2014). Por sua vez, as iPSC surgiram com a promessa de contornar as limitações das células tronco embrionárias, elas também são pluripotentes, são isentas dos problemas éticos em relação ao uso de embriões, podem ser produzidas a partir de biópsias de qualquer tecido somático maduro e assim gerar células específicas do paciente, descartando o problema de imunocompatibilidade do órgão do doador e do transplantado. No entanto, essa alteração genética pode resultar na formação de teratomas (as chances são maiores comparado às embrionárias) e, apesar de atualmente muitos protocolos terem reduzido drasticamente a formação de tumores, essa possibilidade ainda representa um risco (Li et al., 2008; Yamanaka, 2009; Chiou et al., 2013). Isso se deve ao fato de que o alto potencial de diferenciação é indissociável de alto poder replicativo. Em relação às células tronco neurais (CTN), elas podem ser encontradas do SNC em desenvolvimento e em regiões específicas do cérebro adulto, elas são multipotentes e comprometidas com a linhagem neural, ou seja, podem se diferenciar em astrócitos, oligodendrócitos e neurônios (Gage, 2000). Elas são fortes candidatas para repor as células perdidas do SNC após lesão, 
reconstruindo as vias neuronais, e possuem um risco reduzido na formação de tumores, porém possuem a desvantagem de serem difíceis de obter e geralmente em número reduzido (Jiang et al., 2012). Outro tipo celular amplamente utilizado são as células tronco mesenquimais (CTM). As vantagens desse tipo celular são a fácil obtenção (podem ser extraídas, por exemplo, da medula óssea, cordão umbilical, polpa dentária e tecido adiposo), elas possuem ação imunomodulatória e por isso não sobrem ação do sistema imunológico (não precisam de imunossupressão), são capazes de modular o microambiente (por ex. diminuindo a resposta inflamatória) e podem servir de veículo para liberação de drogas e/ou fatores neurotróficos, que influenciam no crescimento, sobrevivência e diferenciação dos neurônios. As CTM são capazes de se diferenciarem em vários tipos celulares, como osso, gordura, tendão, cartilagem e músculo (Mehlhorn et al., 2006), porém possuem limitado potencial neurogênico. De fato, estudos do nosso grupo, mostram que as CTM, quando colocadas em um meio de cultura específico para o crescimento e diferenciação celular, são capazes de gerar células com características fenotípicas de neurônios, porém essas novas células não são capazes de disparar potencial de ação, característica fundamental de um neurônio maduro (Lepski et al., 2010). No entanto, uma vez transplantadas em um milieu favorável à neurogênese, como por exemplo o tecido hipocampal, suplantase a limitação para neurogênese e alcança-se maturação completa com potenciais de ação e formação de novos circuitos no tecido hospedeiro (Lepski et al., 2011).

O transplante de células tronco para o tratamento da lesão medular é baseada em dois grandes propósitos: I) na tentativa de reparo da região, ou seja, 
repondo neurônios e outras células danificadas do SNC, ou II) na tentativa de modular o microambiente, seja atuando como veículo para entrega de drogas in situ, fornecendo fatores neurotróficos como o fator neurotrófico derivado da glia (GDNF), fator de crescimento nervoso (NGF) ou fator neurotrófico derivado de cérebro (BDNF), ou modulando a resposta imunológica/inflamatória, na tentativa de proteger o neurônio da morte celular e induzir a neuroplasticidade e regeneração (figura 2) (Gage, 2000; Eftekharpour et al., 2008; Siddiqui et al., 2015). Diversos estudos mostraram que o transplante de células tronco após a lesão medular promove a regeneração do axônio e a recuperação funcional; para uma revisão a respeito, vide (Li e Lepski, 2013); no entanto, o benefício dessas células para o tratamento de déficits motores induzidos é limitado e, em relação à dor neuropática, é ainda mais incerto. Sendo assim, é de senso comum a necessidade de uma investigação aprofundada neste sentido antes de terapias celulares restauradoras serem aplicadas em ensaios clínicos.

Em vista do exposto, concentramo-nos no estudo do possível potencial analgésico de transplantes celulares na medula lesada. Em estudos prévios com células tronco neurais fetais (CTNf), nosso grupo demonstrou a diferenciação neuronal de células extraídas das vesículas telencefálicas mesmo após longos períodos in vitro (Maciaczyk et al., 2008; Maciaczyk et al., 2009). Cerca de 60\% das células neuronais maduras obtidas pela diferenciação in vitro assumiram o fenótipo GABAérgico (GABA - Gamma-AminoButyric Acid) em marcações imunocitoquímicas (Maciaczyk et al., 2008). Além disso, todas as células neuronais derivadas de células tronco fetais diferenciadas in vitro apresentaram correntes sinápticas GABAérgicas em registros de patch-clamp (Lepski et al., 
2013). Células GABAérgicas são excitatórias numa fase inicial do seu desenvolvimento, por ausência de um cotransportador de cloro e potássio, mas se tornam inibitórias com o avanço da maturação (Ge et al., 2006). Baseado nesses achados, hipotetizamos que as células precursoras GABAérgicas poderiam eventualmente causar potenciais inibitórios pós-sinápticos e, consequentemente, reverter a hiperexcitabilidade estabelecida no corno dorsal da medula espinal lesada.

Adicionalmente, sabe-se que vias descendentes inibitórias serotoninérgicas e noradrenérgicas, provenientes do núcleo magno da rafe e do locus ceruleus, atingem o corno posterior da medula e atuam inibindo a transmissão dolorosa (Basbaum e Fields, 1978; Terman et al., 1984; Morgan et al., 1992), como parte do sistema supressor de dor. Ora foi demonstrado (Fuentealba et al., 2015) que há certo determinismo fenotípico na maturação de células provenientes de regiões distintas do encéfalo do embrião. Segundo essa teoria, células do mesencéfalo ventral tenderiam a diferenciar-se em células dopaminérgicas, ao passo que neuroblastos da eminência gangliônica periventricular tenderiam a formar células GABAérgicas e células da região ponto bulbar ventral culminariam em células serotoninérgicas e noradrenérgicas. Dessa forma, perguntamo-nos se precursores neurais da porção ponto bulbar ventral do tronco encefálico ou das vesículas telencefálicas teriam potenciais distintos de diferenciação no corno posterior da medula lesada, apresentando assim possíveis efeitos analgésicos. 


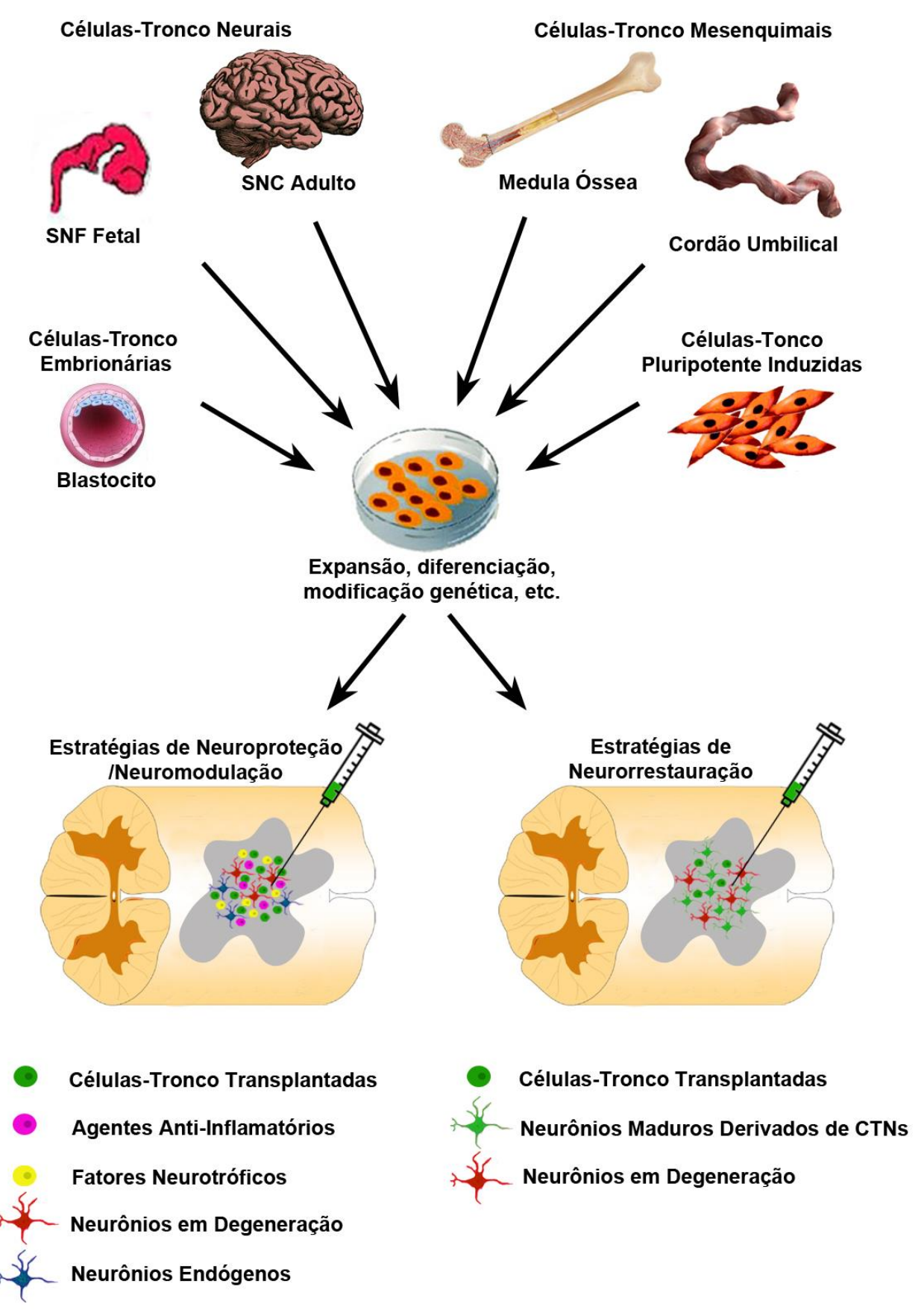

FONTE: Desenvolvido pela autora, 2018.

Figura 2: Esquema representativo de diferentes fontes de células tronco e abordagens para o reparo da medula espinal após lesão. Diversos tipos de células tronco, embrionárias, neurais, mesenquimais ou pluripotentes induzidas, têm sido estudadas para o tratamento da lesão medular. A terapia celular tem dois objetivos principais: restaurar a área lesada, substituindo neurônios e outras células perdidas do SNC, ou modulando o microambiente, liberando fatores neurotróficos e agentes anti-inflamatórios que resultam na proteção da morte neuronal e na indução da neuroplasticidade. 


\section{OBJETIVOS}




\section{OBJETIVOS}

\subsection{Gerais}

O objetivo do presente estudo foi avaliar a capacidade do transplante de CTNf extraídas das vesículas telencefálicas e da região ponto bulbar ventral em promover a inibição da sensação dolorosa e, secundariamente, a recuperação motora, em animais submetidos à lesão traumática da medula espinal. Ademais, tivemos como objetivo avaliar até que ponto CTNf de diferentes regiões são capazes de gerar neurônios de diferentes fenótipos na medula espinal lesada e que tipo de conexão é estabelecida.

Para que o objetivo do estudo fosse alcançado, foi realizado primeiramente um piloto para indicar o melhor modelo animal a ser utilizado.

\subsection{Específicos}

I. Projeto Piloto: Análise da relação entre a intensidade da lesão vs. dor crônica para definição do modelo animal. Caracterização do tempo de persistência do quadro neuropático.

$\checkmark$ Estabelecimento do modelo animal: Comparação entre lesão medular traumática de intensidade leve e moderada. Avaliação dos déficits referentes à motricidade, sensibilidade e função vegetativa, bem como suas evoluções, através dos testes BBB, filamentos de von Frey, retirada da cauda e recuperação vesical; 
$\checkmark$ Quantificação da perda neuronal por meio da técnica de estereologia em microscópio de epifluorescência e da extensão da lesão através da técnica de imunohistoquímica.

II. Projeto Principal: Análise do poder antiálgico de transplantes de CTNf após lesão medular traumática.

$\checkmark$ Avaliação dos déficits referentes à motricidade e sensibilidade, bem como suas evoluções, através dos testes BBB, plano inclinado, monitor de atividades, filamentos de von Frey e placa quente, após lesão medular de intensidade moderada e tratamento com CTNf provenientes das vesículas telencefálicas ou da região ponto bulbar ventral de fetos $\mathrm{E} 14$;

$\checkmark$ Localização e quantificação da diferenciação neuronal das células transplantadas por meio de estereologia em microscópio de epifluorescência. 
MATERIAIS E MÉTODOS 


\section{MATERIAIS E MÉTODOS}

\subsection{Projeto Piloto}

\subsubsection{Procedimento Cirúrgico}

Todos os procedimentos cirúrgicos e métodos de manipulação do presente trabalho foram previamente aprovados pelo Comitê de Ética da Faculdade de Medicina da Universidade de São Paulo (protocolo número 033/14). Ratos Wistar de 250 a $300 \mathrm{~g}$ foram submetidos à anestesia geral intraperitoneal com cetamina $(100 \mathrm{mg} / \mathrm{Kg})$ e xilazina $(10 \mathrm{mg} / \mathrm{Kg})$. Após tricotomia e antissepsia da área cirúrgica, foi realizada uma incisão longitudinal dorsal mediana da pele na topografia de T7 a T12, em seguida, a musculatura paravertebral foi cuidadosamente afastada com dissectores. Foi realizada uma laminectomia em nível de T9 e T10 expondo a medula espinal e a dura-máter intacta. A lesão medular traumática foi promovida por um equipamento desenvolvido na Universidade de Nova lorque, denominado NYU Impactor (figura 3). Os animais foram fixados pelas vértebras superior e inferior àquela submetida à laminectomia utilizando-se grampos vertebrais específicos. A seguir, um peso de 10 gramas foi solto de uma altura de $12,5 \mathrm{~mm}$ ou de $25 \mathrm{~mm}$ para a promoção de uma lesão contusa de intensidade leve ou moderada, respectivamente (Gruner, 1992). Um grupo de animais foi submetido à cirurgia sham (receberam laminectomia sem lesão medular) e outro grupo controle não foi submetido a nenhuma intervenção cirúrgica, apenas anestesia. Durante o procedimento cirúrgico, a reposição de volume foi realizada através da injeção intraperitoneal de solução salina aquecida. 
Após o término dos procedimentos, foi realizada a sutura dos planos musculares, subcutâneo e pele. Os animais foram mantidos em ciclo claro-escuro de 12 horas, em livre demanda de alimento e água. Todos os animais (incluindo o controle) receberam injeção subcutânea de Flotril $(1 \mathrm{mg} / \mathrm{Kg})$ durante três dias e Dipirona $(1 \mathrm{mg} / \mathrm{Kg})$ durante cinco dias e o esvaziamento vesical foi realizado duas vezes ao dia até o retorno da função.

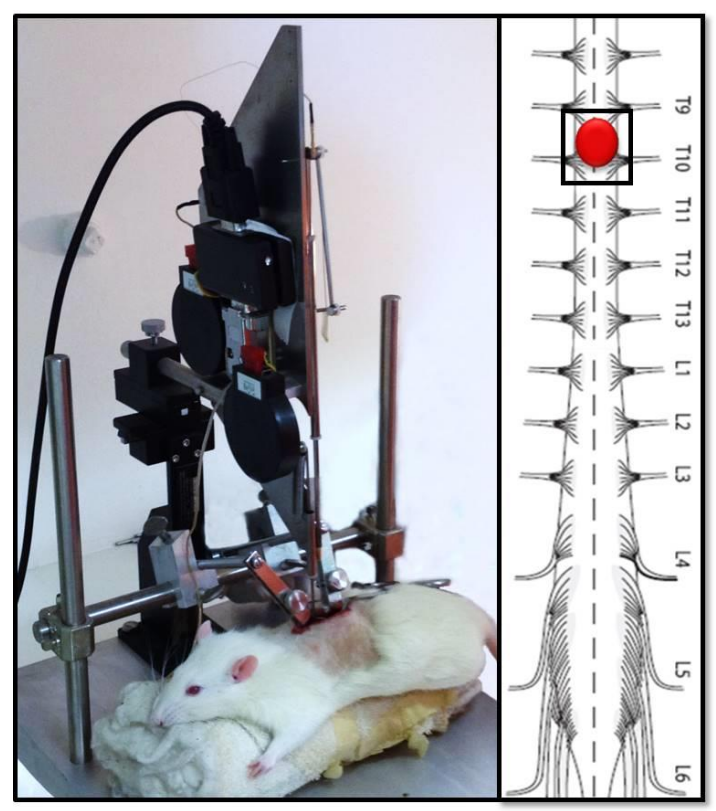

Figura 3: Animal posicionado no aparelho NYU Impactor. A figura da direita representa o local onde foi realizada a lesão medular traumática.

\subsubsection{Grupos Experimentais do Piloto}

Desta forma foram obtidos quatro grupos experimentais:

- Grupo Controle: sem nenhuma intervenção cirúrgica, apenas anestesia $(n=5)$;

- Grupo Laminectomia: submetidos à laminectomia, sem lesão medular $(n=5)$; 
- Grupo LL: submetidos à lesão medular leve, altura do pêndulo de $12,5 \mathrm{~mm}$ $(n=11)$;

- Grupo LM: submetidos à lesão medular moderada, altura do pêndulo de $25 \mathrm{~mm}(\mathrm{n}=11)$.

\subsection{2. Índice de Recuperação Vesical}

O índice de recuperação vesical foi realizado diariamente através da medida látero-lateral da bexiga antes do esvaziamento. $\mathrm{O}$ tamanho da bexiga indica o índice percentual da recuperação vesical (tabela 2).

Tabela 2: Relação do tamanho da bexiga vs. grau de recuperação vesical.

\section{Tamanho da bexiga \% de Recuperação}

\begin{tabular}{|c|c|}
\hline $2 \mathrm{~cm}$ & $0 \%$ \\
\hline $1,5 \mathrm{~cm}$ & $25 \%$ \\
\hline $1,0 \mathrm{~cm}$ & $50 \%$ \\
\hline $0,5 \mathrm{~cm}$ & $75 \%$ \\
\hline $0 \mathrm{~cm}$ & $100 \%$ \\
\hline
\end{tabular}

\subsubsection{Avaliação Motora}

\subsubsection{1. Índice $B B B$}

A avaliação locomotora dos ratos foi estimada através da escala BBB (Basso, Beattie e Bresnahan), cujos escores representam os estágios sequenciais de recuperação que os ratos demonstram após lesão medular. Sua pontuação varia de 0 a 21 (tabela 3), onde 0 representa nenhum movimento espontâneo das patas traseiras e um escore de 21 indica locomoção normal (Basso et al., 1996). O BBB foi realizado no $1^{\circ}, 3^{\circ}, 5^{\circ}$ e $7^{\circ}$ dia após a cirurgia e depois semanalmente até o final de oito semanas (figura 6, A e B). 


\subsubsection{Avaliações Sensitivas}

\subsubsection{Filamentos de Von Frey}

A avaliação da alodínia mecânica foi realizada utilizando filamentos de von Frey (Chaplan et al., 1994). Os ratos foram colocados em gaiolas com o fundo de tela de arame que permitiu acesso total as patas (figura 7, C). Os animais foram mantidos por aproximadamente 15 minutos na gaiola antes do início do teste para que explorassem a área e cessassem as principais atividades de higiene. Foram testadas as patas traseiras e dianteiras. Cada pata foi tocada com um de uma série de oito filamentos de von Frey, sendo que cada filamento representa uma força em gramas (de 0.41 a $15,10 \mathrm{~g}$, tabela 4) e indica o grau de pressão que o animal consegue suportar antes de demonstrar desconforto. O filamento de von Frey foi apresentado perpendicular à superfície plantar com força suficiente para provocar uma ligeira deformação contra a pata e mantido durante 6-8s. Os estímulos foram realizados em intervalos de alguns segundos. Foi considerada como resposta positiva a retirada da pata (ou a tentativa de retirada) logo após o estímulo, bem como o estremecimento imediatamente após a remoção do filamento. A avaliação foi feita no $1^{\circ}, 3^{\circ}, 5^{\circ}$ e $7^{\circ}$ dia após a cirurgia e depois semanalmente até o final de oito semanas. 
Tabela 3: Escala locomotora BBB

0 Sem movimento do membro posterior.

1 Movimento perceptível de uma ou duas articulações, geralmente quadril e/ou joelho.

2 Movimento amplo de uma articulação ou movimento amplo de uma articulação e movimento perceptível de outra.

3 Movimento amplo de duas articulações.

4 Movimento perceptível de todas as três articulações do membro posterior (quadril, joelho e tornozelo).

5 Movimento perceptível de duas articulações e movimento amplo da terceira.

6 Movimento amplo de duas articulações e movimento perceptível da terceira.

7 Movimento amplo de todas as três articulações do membro posterior.

8 Arrasta sem suporte de peso ou colocação plantar da pata sem suporte de peso.

9 Colocação da pata com suporte de peso somente quando parado (em posição estática) ou passos com apoio dorsal e suporte de peso ocasionais, freqüentes ou consistentes e sem passos com apoio plantar.

10 Passos com apoio plantar e suporte de peso ocasionais, sem coordenação do membro anterior e membro posterior (MA e MP).

11 Passos com apoio plantar e suporte de peso frequentes ou consistentes e sem coordenação MA-MP.

12 Passos com apoio plantar e suporte de peso frequentes ou consistentes e coordenação MA-MP ocasional.

13 Passos com apoio plantar e suporte de peso consistentes e coordenação MA-MP frequente.

14 Passos com apoio plantar e suporte de peso consistentes, coordenação MA-MP consistente e posição predominante da pata durante locomoção é em rotação ou passos com apoio plantar freqüentes, coordenação MA-MP consistente e passos com apoio dorsal ocasionais.

15 Coordenação MA-MP consistente e arrasta dedos ao longo do passo.

16 Coordenação MA-MP consistente durante a marcha e frequentemente não arrasta os dedos; a posição predominante da pata é paralela no contato inicial do passo e rodada na fase de retirada.

17 Coordenação MA-MP consistente durante a marcha e frequentemente não arrasta os dedos; a posição predominante da pata é paralela no contato inicial do passo e na fase de retirada.

18 Coordenação MA-MP consistente durante a marcha e consistentemente não arrasta os dedos; a posição predominante da pata é paralela no contato inicial do passo e rodada na fase de retirada.

19 Coordenação MA-MP consistente durante a marcha e consistentemente não arrasta os dedos; a posição predominante da pata é paralela no contato inicial do passo e na fase de retirada e cauda para baixo parte do tempo.

20 Marcha coordenada consistente, consistentemente não arrasta os dedos; a posição predominante da pata é paralela no contato inicial do passo e na fase de retirada mas há instabilidade do tronco e cauda para cima consistentemente.

21 Marcha coordenada consistente, consistentemente não arrasta os dedos; a posição predominante da pata é paralela no contato inicial do passo e na fase de retirada, tronco estável e cauda para cima consistentemente. 
Tabela 4: Espessura vs. força em gramas de cada filamento de von Frey

\begin{tabular}{|c|c|}
\hline Filamentos & Gramas \\
\hline 3,61 & $0,407 \mathrm{~g}$ \\
\hline 3,84 & $0,692 \mathrm{~g}$ \\
\hline 4,08 & $1,202 \mathrm{~g}$ \\
\hline 4,17 & $1,479 \mathrm{~g}$ \\
\hline 4,31 & $2,041 \mathrm{~g}$ \\
\hline 4,56 & $3,630 \mathrm{~g}$ \\
\hline 4,74 & $5,495 \mathrm{~g}$ \\
\hline 4,93 & $8,511 \mathrm{~g}$ \\
\hline 5,07 & $11,749 \mathrm{~g}$ \\
\hline 5,18 & $15,136 \mathrm{~g}$ \\
\hline
\end{tabular}

\subsubsection{Retirada da Cauda}

A avaliação do limiar nociceptivo foi realizada através do teste de retirada da cauda (tail flick). Os animais foram colocados em uma gaiola de contenção na qual suas caudas se projetavam para fora (figura 7, B). O calor da lâmpada de halogéneo de $8 \mathrm{~V}, 50 \mathrm{~W}$, foi focado no terço inferior da cauda (Tail Flick, Analgesia Meter, Columbus Instruments, EUA). O movimento da cauda ativa uma fotocélula, desligando a luz e um temporizador de reação. O tempo máximo para a retirada da cauda foi de $8 \mathrm{~s}$, para evitar possíveis lesões. A análise consistiu na média de dois testes individuais separados por um intervalo de 30 minutos (Dale et al., 2006). O teste retirada da cauda foi realizado no $1^{\circ}, 3^{\circ}, 5^{\circ}$ e $7^{\circ}$ dia após a cirurgia e depois semanalmente até o final de oito semanas.

\subsubsection{Imunofluorescência e Imunohistoquímica}

Após o término de oito semanas, os animais foram anestesiados com cetamina $(100 \mathrm{mg} / \mathrm{Kg})$ e xilazina $(10 \mathrm{mg} / \mathrm{Kg})$ e eutanasiados através de uma perfusão transcardíaca de solução salina, seguida de solução fixadora que 
consiste de $4 \%$ de paraformaldeído diluído em tampão fosfato $(0,1 \mathrm{M} ; \mathrm{pH} 7,4)$. Suas medulas espinais foram extraídas e um segmento de $2 \mathrm{~cm}$ incluindo toda área da lesão (cortado $1,0 \mathrm{~cm}$ acima e 1,0 cm abaixo do epicentro da lesão) foi congelado utilizando isopentano e gelo seco. Cortes seriados de $40 \mu \mathrm{m}$ foram obtidos com a utilização de um criostato (Leica, CM3000) de todo segmento medular.

Imunohistoquímica: Secções de todo o segmento medular obtido (acima, abaixo e na área da lesão) foram marcadas com hematoxilina e eosina (HE). Em seguida, foi realizada a quantificação da extensão da lesão, através da observação do tecido medular preservado e danificado de cada animal.

Imunofluorescência: Em suma, as secções foram lavadas em tampão fosfato salino (PBS) e incubadas em uma solução de bloqueio contendo $4 \%$ de soro de cabra e $0,1 \%$ de Triton X-100 em PBS durante uma hora em temperatura ambiente. A seguir, as secções foram incubadas durante 24 horas a $4^{\circ} \mathrm{C}$ com o anticorpo primário Neuronal Nuclei (NeuN, 1:1.000; Millipore-MAB377). Após novas lavagens, as secções foram incubadas com o respectivo anticorpo secundário Alexa Fluor 594 na concentração de 1:150 e mais o DAPI na concentração de 1:1.000, durante 2 hora em temperatura ambiente. Depois de uma nova série de lavagens em PBS, as lamínulas foram montadas sobre as lâminas embanhando os cortes em fluorescent mounting médium (Dako), para preservação da reação de imunofluorescência.

Quantificação estereológica: A contagem de neurônios (células NeuN positivas) foi realizada em todas as seções acima, abaixo e na área da lesão, em toda substância cinzenta da medula espinhal, usando um microscópio Zeiss Axio 
Imager A2 (Carl Zeiss, Alemanha) e o software Zen blue (Carl Zeiss, Alemanha). O número total de células NeuN positivas foi estimado usando a fórmula de correção de Abercrombie, como segue: $P=M /(D+M) A^{*} N$, onde $P=$ número total de células, $M=e$ espessura de secção, $D=$ diâmetro médio das células positivas, $\mathrm{A}=$ número de células contadas e $\mathrm{N}=$ número de séries de corte (Abercrombie, 1946).

\subsection{Projeto Principal}

\subsubsection{Isolamento das Células Tronco Neurais Fetais}

Células tronco neurais foram isoladas de fetos E14 (com 14 dias de vida intrauterina) de ratos Wistar. Em suma, fêmeas prenhas foram anestesiadas com injeção intraperitoneal de Cetamina $(100 \mathrm{mg} / \mathrm{Kg})$ e Xilazina $(10 \mathrm{mg} / \mathrm{Kg})$, a cavidade abdominal foi aberta e o útero removido. Em seguida, os fetos foram extraídos e o tecido neural foi isolado de seus envoltórios (figura 4, A-C). As células foram extraídas de duas regiões distintas, das vesículas telencefálicas (VT) e da região ponto bulbar ventral (BV).

As regiões dissecadas foram digeridas com tripsina $0,1 \%$ (Worthington, EUA) durante 12 minutos a $37^{\circ} \mathrm{C}$ seguido de DNase (Worthington, EUA) $0,05 \%$ durante 12 minutos a $37^{\circ} \mathrm{C}$. Após trituração mecânica, a suspensão resultante foi cultivada em meio contendo DMEM/F12, 1\% de suplemento B27 (Gibco), 1\% de penicilina, estreptomicina e anfoterecina (PSA, Gibco), 20ng/mL de fator de crescimento epidermal (EGF, Sigma), 20ng/mL de fator de crescimento fibroblástico básico (bFGF, Sigma) e $5 \mu \mathrm{g} / \mathrm{mL}$ de heparina (Sigma) e incubadas a 
$37^{\circ} \mathrm{C}, 5 \%$ de $\mathrm{CO}_{2}, 21 \%$ de $\mathrm{O}_{2}$ e $95 \%$ de humidade (figura $2, \mathrm{D}-\mathrm{G}$ ). $\mathrm{O}$ meio foi trocado a cada dois dias e as passagens das neuroesferas formadas foram realizadas por meio de dissociação química leve (3 minutos em tripsina EDTA a $\left.37^{\circ} \mathrm{C}\right)$ (Lepski et al., 2011).

Para marcar as células que foram transplantadas, foi adicionado ao meio

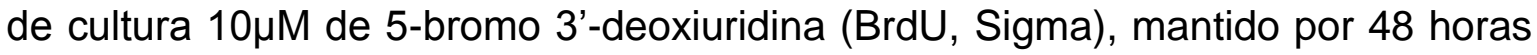
antes das sessões de transplante celular.

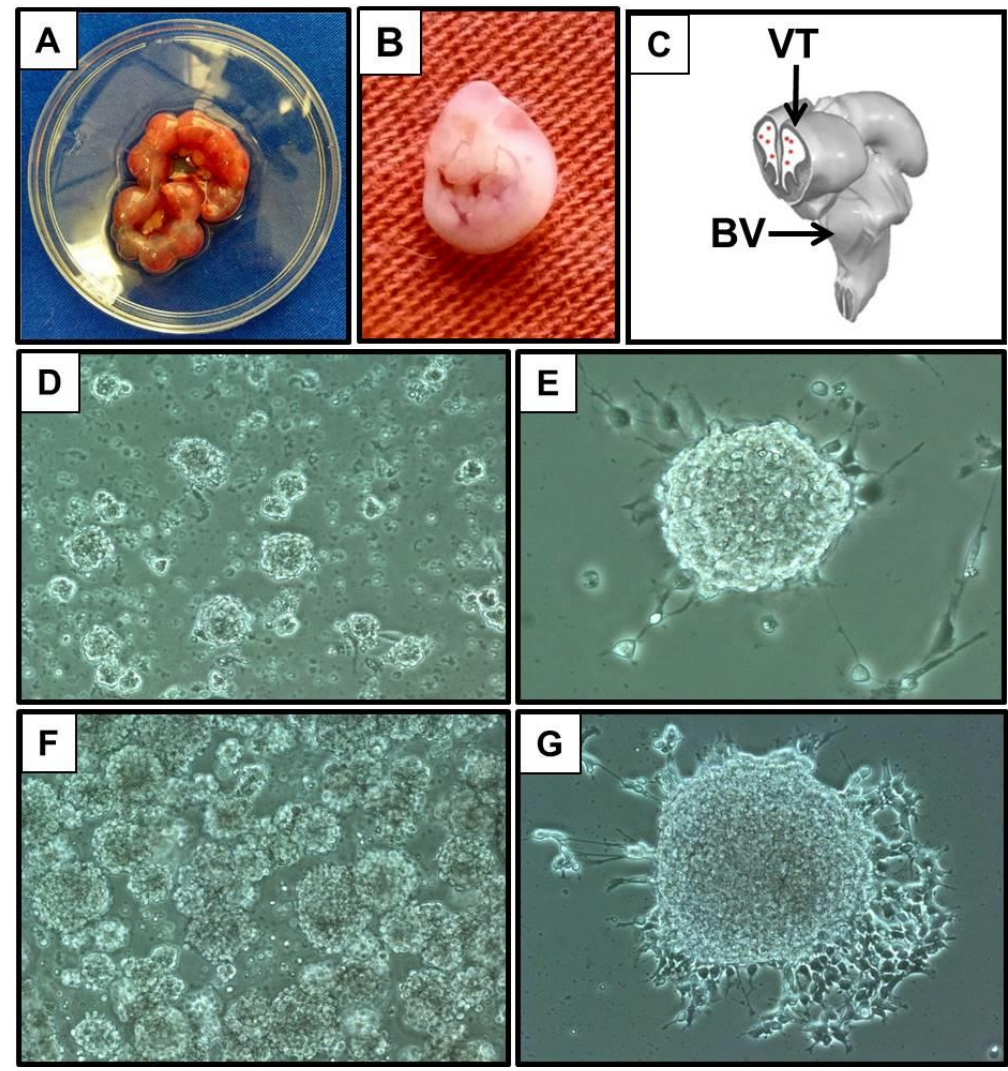

Figura 4: Extração e cultura de células tronco neurais fetais (CTNf) de embriões com 14 dias de vida intra-uterina. (A) fotografia do saco uterino após explantação por laparotomia, (B) fotografia de um embrião, (C) imagem representativa das regiões cerebrais isoladas do embrião, (D) cultura de CTNf extraídas das vesículas telencefálicas (VT) dois dias após a extração, (E) cultura de CTNf extraídas das VT uma semana após a extração, (F) cultura de CTNf extraídas da região ponto bulbar ventral (BV) dois dias após a extração e (E) cultura de CTNf extraídas da região BV uma semana após a extração. 


\subsubsection{Procedimento Cirúgico}

\subsubsection{Lesão Medular Traumática}

Quarenta e cinco ratos Wistar de 250 a $300 \mathrm{~g}$ foram submetidos à lesão medular traumática de intensidade moderada (altura do pêndulo $25 \mathrm{~mm}$ ), em nível de T9-T10, conforme descrito anteriormente (mesmo protocolo de lesão medular e cuidados no pós-operatório). A lesão moderada foi escolhida por ter proporcionado no piloto dor neuropática francamente identificável segundo os métodos de mensuração comportamentais escolhidos, que se manteve durante o período de tempo necessário para hipotética maturação das células-tronco no tecido hospedeiro (2 meses). Outro grupo de animais controle não foi submetido a nenhuma intervenção cirúrgica $(n=14)$.

\subsubsection{Imunossupressão}

Sete dias após a lesão medular traumática e três dias antes dos transplantes, todos os animais (incluindo o grupo controle) foram realocados em gaiolas de ventilação isolada (micro isoladores/ Tecniplast) e iniciou-se a imunossupressão através da injeção intraperitoneal diária de ciclosporina (Sandimmun, $10 \mathrm{mg} / \mathrm{kg}$, Novartis). A imunossupressão foi combinada com administração oral profilática de antibiótico (trimetoprima, sulfametoxazol, Bactrim, Roche), colocada na água dos animais. 


\subsubsection{Transplante Celular}

Dez dias após a lesão medular, os animais tiveram sua medula espinal reexposta para o transplante, por meio de reabertura da incisão prévia sob anestesia geral seguido da fixação do animal no aparelho estereotáxico (Leica, Microsystem). A seguir, foi realizada uma injeção estereotáxica de meio de cultivo (DMEM/F12) ou de CTNfs (figura 5). A solução de células foi preparada resuspendendo as culturas com Tripsina-EDTA (Sigma) por 3 minutos a temperatura ambiente, seguido de centrifugação e resuspensão a 5×10^4/uL em meio contendo Dnase 0,05\% para evitar agregação. A viabilidade das células foi assessada imediatamente antes do implante por meio do método de azul Trypan em câmara de Newbauer. Verificou-se viabilidade das células oriundas das VTs de $90 \%$, enquanto a viabilidade das células provenientes da região BV foi de $74 \%$. Inicialmente, micropipetas de vidro foram confeccionadas no laboratório usandose um puller (P-97 Flaming/Brown micropipette puller, Sutter Instrument), programado a modo de se obter pipetas com cerca de $80 \mu \mathrm{m}$ de diâmetro externo, a fim de minimizar o trauma relacionado ao transplante das células na medula. $\mathrm{A}$ seguir, a micropipeta foi acoplada à seringa Hamilton de $25 \mu$ l para injeção, essa última estando acoplada a uma bomba de infusão presa no braço móvel do aparelho estereotáxico (Leica, Microsystem). Os animais receberam um total de $12 \mu \mathrm{L}$ de células em suspensão $\left(5 \times 10^{4}\right.$ céls/ $\left.\mu \mathrm{L}\right)$, divididas em quatro regiões da medula espinal (150.000 células por depósito, total de 600.000 células por animal), duas no local da lesão e duas acima da área de lesão (figura 3). A

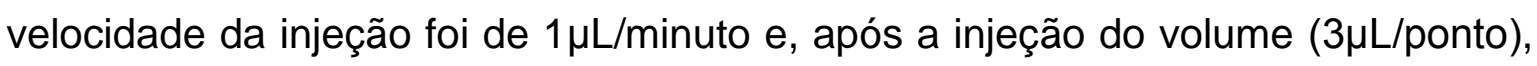
foi esperado 20 segundos para retirar a micropipeta da medula espinal, evitando- 
se assim explante por capilaridade. Após a sutura dos planos musculares, subcutâneo e pele, os animais foram realocados para suas respectivas gaiolas onde foram mantidos em ciclo claro-escuro de 12 horas, em livre demanda de alimento e água.

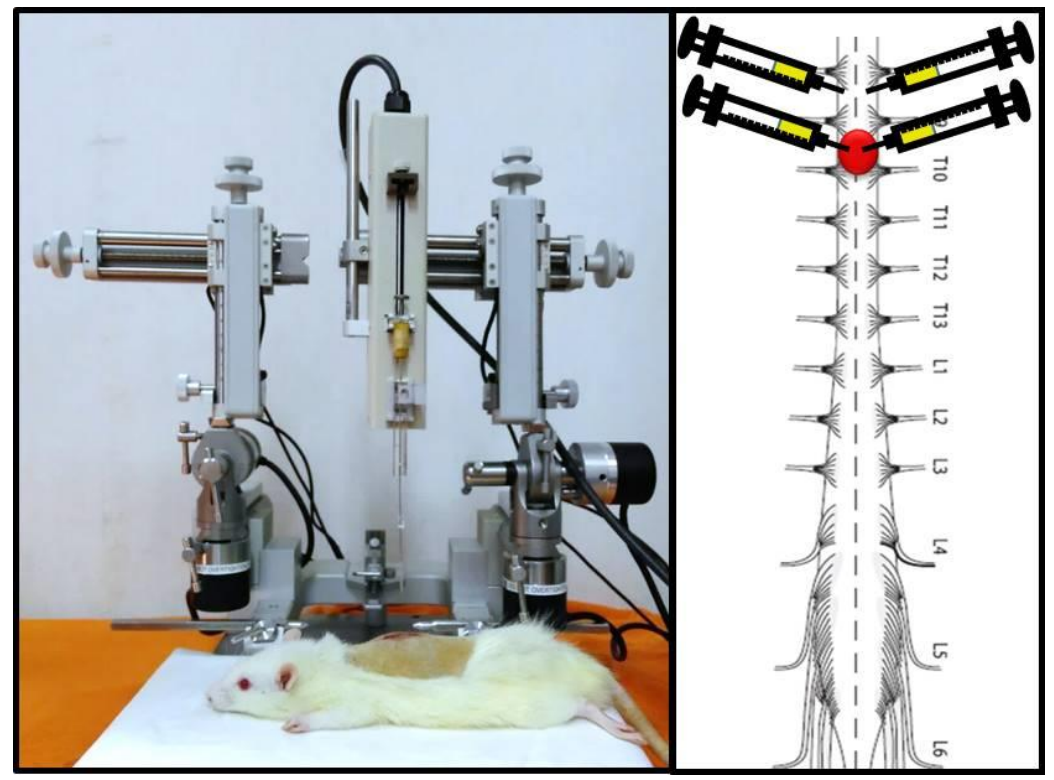

Figura 5: Animal posicionado no aparelho estereotáxico para receber a injeção das células tronco neurais fetais. Observa-se a bomba de infusão presa no braço móvel do estereotáxico. A figura da direita representa os locais onde foram realizados os transplantes.

\subsubsection{Grupos Experimentais do Projeto}

Desta forma, após o transplante das CTNfs, foram obtidos quatro grupos experimentais:

- Grupo Controle: sem cirurgia $(n=14)$.

- Grupo Sham: lesão medular e transplante de meio de cultivo $(n=11)$.

- Grupo VT: lesão medular e transplante de CTNfs extraídas das vesículas telencefálicas $(n=12)$.

- Grupo BV: lesão medular e transplante de CTNfs da região ponto-bulbar ventral $(n=11)$. 


\subsubsection{Avaliações Motoras}

\subsubsection{1. Índice BBB}

A avaliação locomotora dos animais foi realizada através do índice BBB, conforme descrito anteriormente. O BBB foi realizado um dia antes da cirurgia, um dia antes do transplante e depois semanalmente até o final de oito semanas.

\subsubsection{Plano Inclinado}

A avaliação da força e resistência muscular foi realizada através do teste plano inclinado (Rivlin e Tator, 1977). Neste teste, o ângulo do plano é aumentado de zero grau até o ponto em que o rato não consegue se manter na posição (figura 6, C). Para cada animal foi realizada duas mensurações. O plano inclinado foi realizado um dia antes da cirurgia, um dia antes do transplante e depois semanalmente até o final de oito semanas.

\subsubsection{Monitor de Atividades}

O monitor de atividades é um equipamento destinado à monitorização de movimentos do animal nos eixos x, y e z (altura, largura e profundidade) em uma arena cúbica (figura 6, D). No presente estudo foi coletada a distância percorrida, a velocidade média e a quantidade de levantamento do animal. Os animais foram mantidos na arena por 3 minutos antes do início do teste para que explorassem a área, em seguida os dados foram coletados durante o período de 12 minutos. Esse teste foi realizado um dia antes do transplante e depois semanalmente até o final de oito semanas. 


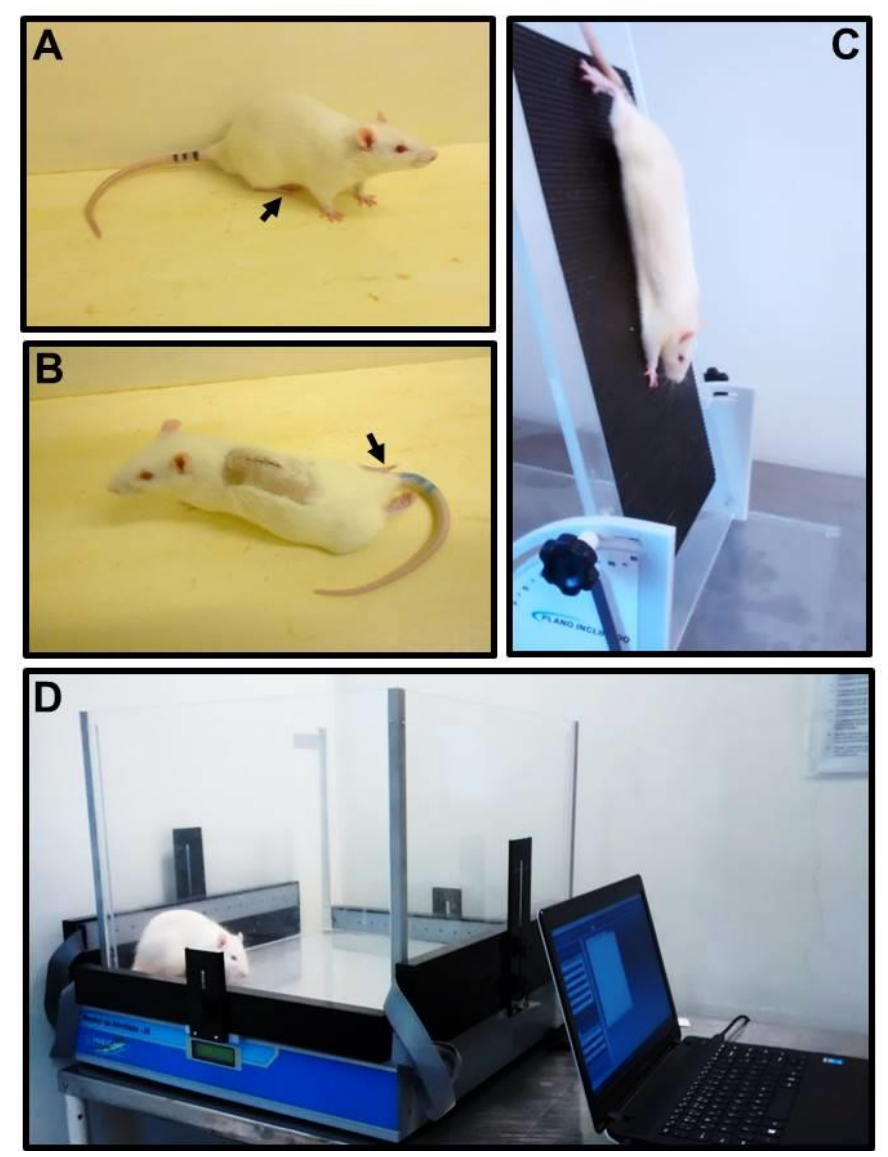

Figura 6: Avaliações motoras. As figuras (A) e (B) mostram o animal durante a análise do $B B B$, sendo que (A) mostra um animal do grupo controle e (B) um animal três dias após a lesão medular de intensidade moderada. A figura (C) mostra a avaliação da força e resistência muscular através do plano inclinado e, por fim, a figura (D) mostra a avaliação do desempenho motor realizado através do monitor de atividades.

\subsubsection{Avaliações Sensitivas}

\subsubsection{Filamentos de Von Frey}

A alodínia mecânica foi avaliada através dos filamentos de von Frey, conforme descrito anteriormente. Referido teste foi realizado um dia antes da cirurgia, um dia antes do transplante e depois semanalmente até o final de oito semanas. 


\subsubsection{Placa Quente}

O teste da placa quente (hot plate) avalia o tempo em que os animais permanecem sobre uma chapa metálica aquecida $\left(50 \pm 0,5^{\circ} \mathrm{C}\right)$ até reagirem ao estímulo térmico com o comportamento de levantar ou lamber as patas ou de vocalização (figura 7, A). O tempo máximo para a retirada da pata foi de 20 s, para evitar possíveis lesões. Foi realizada duas mensurações por animal com um intervalo de 30 minutos entre elas (Dale et al., 2006).

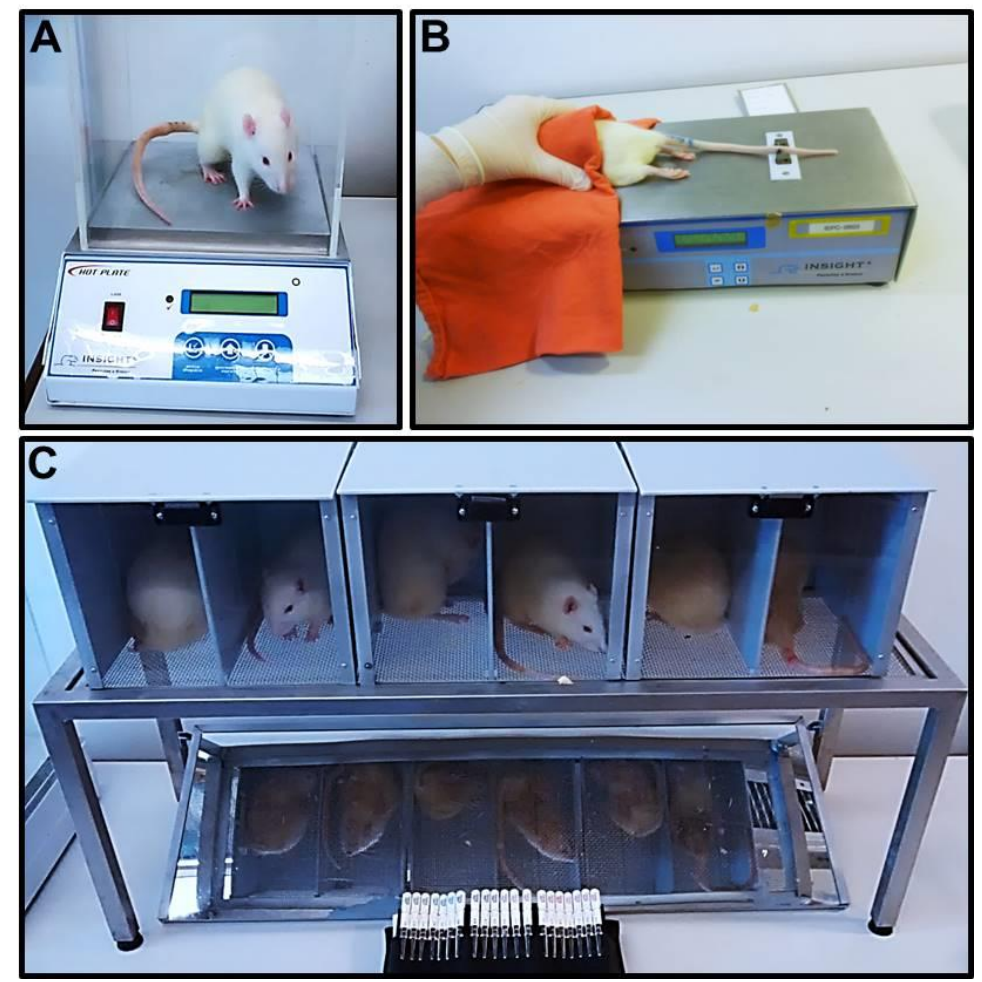

Figura 7: Avaliações sensitivas. $\mathrm{Em}(\mathrm{A})$ análise da hiperalgesia térmica através do teste placa quente, em (B) análise do limiar nociceptivo através do teste retirada da cauda e em (C) análise da alodínea mecânica através do teste filamentos de von Frey.

\subsubsection{Imunofluorescência}

Após oito semanas do transplante celular, os animais foram anestesiados com cetamina $(100 \mathrm{mg} / \mathrm{Kg})$ e xilazina $(10 \mathrm{mg} / \mathrm{Kg})$ e eutanasiados através de uma 
perfusão transcardíaca de solução salina, seguida de solução fixadora que consiste de $4 \%$ de paraformaldeído diluído em tampão fosfato $(0,1 \mathrm{M} ; \mathrm{pH} 7,4)$. Suas medulas espinais foram extraídas e um segmento de $2 \mathrm{~cm}$ incluindo toda área da lesão (cortado 1,0 cm acima e 1,0 cm abaixo do epicentro da lesão) foi congelado utilizando isopentano e gelo seco. Cortes seriados de $60 \mu \mathrm{m}$ foram obtidos de todo segmento medular utilizando um criostato (Leica, CM3000).

Inicialmente, as secções foram lavadas PBS e incubadas em uma solução de bloqueio contendo $4 \%$ de soro de cabra e $0,1 \%$ de Triton X-100 em PBS durante uma hora em temperatura ambiente. A seguir, as secções foram incubadas durante 24 horas a $4^{\circ} \mathrm{C}$ com os anticorpos primários anti-NeuN (1:1.000, Millipore), anti-proteína glial fibrilar ácida (GFAP, 1:500, Millipore), antioligodendrocito (1:500, Millipore), anti-GABA (1:300, Sigma), anti-serotonina (5HT, 1:500, Millipore) e anti-encefalina (1:100, Millipore), duplamente marcados com anti-BRDU feito em coelho (1:100, Abcam) ou em camundongo (1:800, Millipore).

Após novas lavagens com PBS, as secções foram incubadas com o respectivo anticorpo secundário Alexa Fluor (488 e 594) na concentração de 1:150 e mais o DAPI na concentração de 1:1.000, durante 2 hora em temperatura ambiente. Depois de uma nova série de lavagens, as lamínulas foram montadas sobre as lâminas usando o fluorescente mounting médium (Dako), para preservação da reação de imunofluorescência.

Quantificação estereológica: A contagem das células transplantadas foi realizada em todas as secções acima, abaixo e na área da lesão usando o microscópio Zeiss Axio Imager A2 (Carl Zeiss, Alemanha) e o software Zen blue. O número total de células BrdU positiva foi estimado usando a formula de 
correção de Abercrombie, conforme mencionado anteriormente (Abercrombie, 1946).

\subsection{Análise Estatística}

Para as análises estatísticas foram calculadas as medidas resumos dos dados iniciais por métodos convencionais (as variáveis contínuas foram expressas em termos de média, erro padrão e desvio padrão). Gráficos de perfis médios foram construídos (GraphPad Prisma 5) para ilustrar as diferenças entre os grupos, sendo que as barras representam o erro padrão. Os dados foram submetidos aos testes Shapiro-Wilk e D'Agostino-Pearson para avaliar se tinham distribuição normal, permitindo a escolha do teste estatístico mais adequado. Como os dados não obedeceram à distribuição normal foi utilizado o teste Mann Whitney U para comparações de dois grupos e o teste de Kruskal-Wallis seguido do pós-teste de Dunns para comparações de três ou mais grupos. Foram aceitas como variações significativas aquelas em que a diferença entre os grupos resultou em um p igual ou menor que 0,05 . 
RESULTADOS 


\section{RESULTADOS}

\subsection{Resultados do Projeto Piloto}

\subsubsection{Análise do Peso Corporal e da Recuperação Vesical}

A análise do ganho de massa corpórea mostrou que os animais submetidos à lesão medular traumática de intensidade leve tiveram uma diminuição do seu peso corporal uma semana após a lesão, com um aumento crescente ao longo das semanas seguintes de avaliação. Todos os outros grupos apresentaram ganho de peso progressivo logo após a lesão (figura 8, A). Em relação ao grau de recuperação vesical, os animais de ambos os grupo com lesão medular apresentaram uma recuperação espontânea ao longo do tempo, no entanto, a recuperação do grupo LL foi mais rápida, cerca de oito dias após a lesão, quando comparado com o grupo LM, o qual demorou cerca de duas semanas (figura $8, B$ ).

\subsubsection{Avaliação Motora}

A avaliação locomotora através da escala BBB mostrou uma melhora inicial do grupo LL mais acentuada, com progressão funcional lenta e contínua até o final do período de avaliação, atingindo $71 \%$ da função normal no final da oitava semana. Por outro lado, uma ligeira recuperação foi observada no grupo LM nas três primeiras semanas após a lesão, atingindo um platô de $30 \%$ da função normal a partir de então (figura $8, \mathrm{C}$ ). 
A

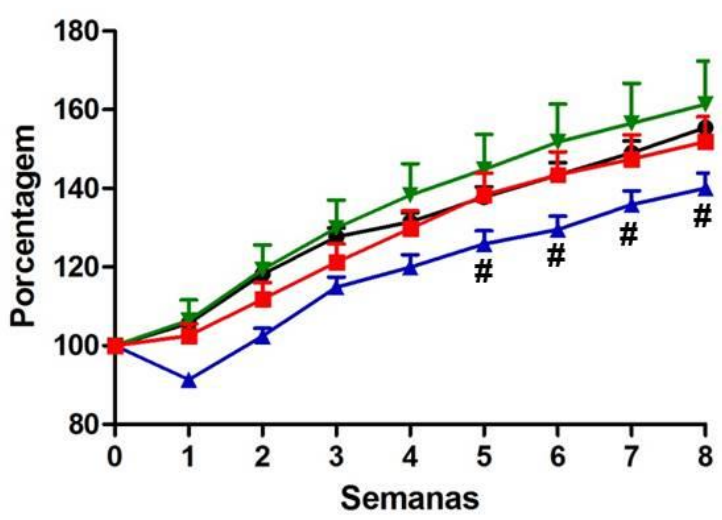

C

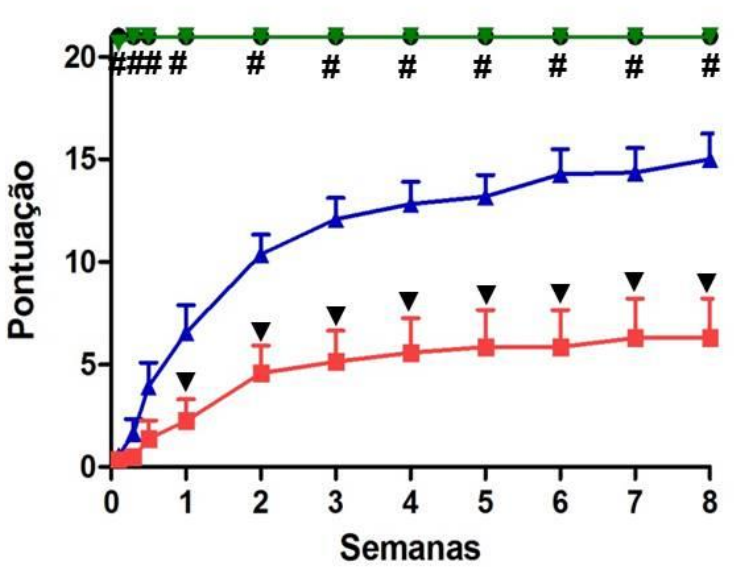

B Recuperação Vesical

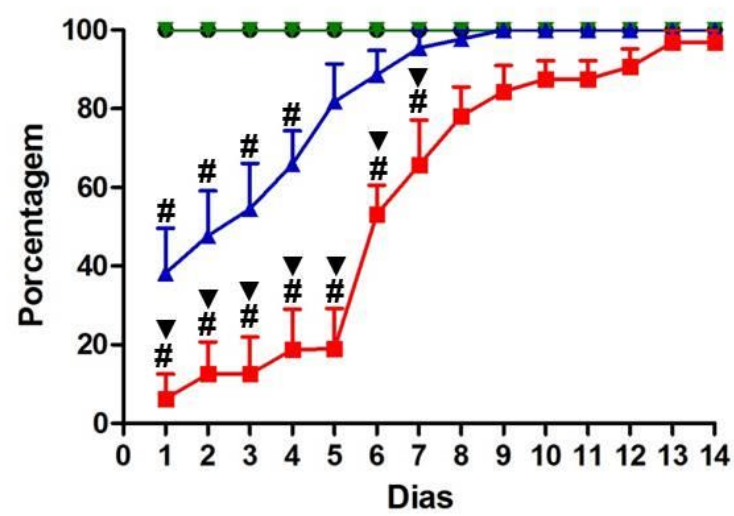

Figura 8: Análise do peso corporal, da função vesical e da locomoção através da escala BBB. (A) Peso: todos os grupos apresentaram ganho de peso progressivo imediatamente após a lesão, com exceção do grupo com lesão leve (LL), no qual os animais perderam peso na primeira semana com subsequente ganho de peso (\# p<0,05; LL vs controle). (B) Função vesical: os grupos LL e lesão moderada (LM) diferiram significativamente em relação ao funcionamento inicial e recuperação da bexiga após a lesão $\left(\boldsymbol{\nabla} p<0,01\right.$ na $1^{\underline{a}}$ e $7^{\underline{a}}$ semana, $\nabla p<0,001$ entre a $2^{\underline{a}}$ e $6^{\underline{a}}$ semana); enquanto o grupo LL atingiu função normal no $8^{\circ}$ dia de pós-operatório, o grupo LM recuperou-se completamente apenas no $14^{\circ}$ dia (\#p<0,001 em relação aos grupos controle e laminectomia). (C) Avaliação motora: O grupo LL apresentou uma melhora progressiva na função motora, iniciando logo após a lesão e continuando até o final das oito semanas de avaliação; no entanto, o grupo LM atingiu um platô na $3^{a}$ semana pós-lesão e permaneceu nesse nível até o final do período de avaliação ( $\boldsymbol{\nabla} p<0,05$ na $1^{\text {a }}$ semana e $\boldsymbol{\nabla} p<0,001$ entre a $2^{\mathrm{a}}$ e $8^{\mathrm{a}}$ semana). Ambos os grupos LL e LM diferiram do grupo controle e laminectomia $(\# p<0,001)$. Kruskal-Wallis seguido pelo pós-teste de Dunns. 


\subsubsection{Avaliação Sensitiva}

A avaliação da alodínia mecânica, através dos filamentos de von Frey não mostrou nenhuma diferença entre os grupos experimentais nas patas anteriores (figura 9, A). Em contrapartida, notou-se um aumento significativo nas patas traseiras em ambos os grupos com lesão medular quando comparados aos grupos controle e laminectomia $(p<0,01)$. $O$ grupo $L L$ teve uma piora até a $3^{\text {a }}$ semana pós-lesão e, posteriormente, foi observada uma melhora espontânea parcial. Por outro lado, o grupo LM apresentou uma deterioração progressiva até o final da avaliação (figura 9, B). Na 6 $6^{\underline{a}}, 7^{\text {a }}$ e $8^{\text {a }}$ semana pós-lesão, o grupo com lesão leve apresentou melhor status funcional em relação ao grupo com lesão moderada ( $p<0,05$ na $6^{\underline{a}}$ semana, $p<0,01$ na $7^{\underline{a}}$ semana e $p<0,05$ na $8^{\underline{a}}$ semana).

Em contrapartida, a avaliação do teste retirada da cauda não mostrou diferenças entre os grupos experimentais ao longo do período avaliado (figura 9, C). 
A

Filamentos de Von Frey

Patas Anteriores

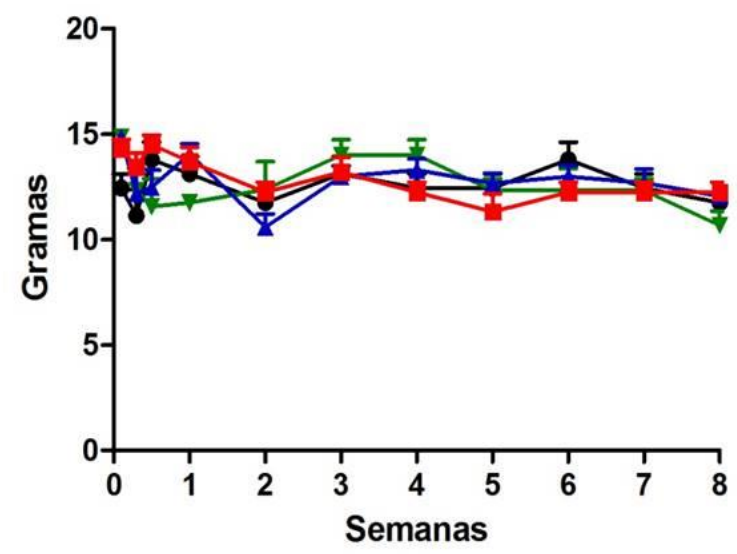

C Retirada da Cauda

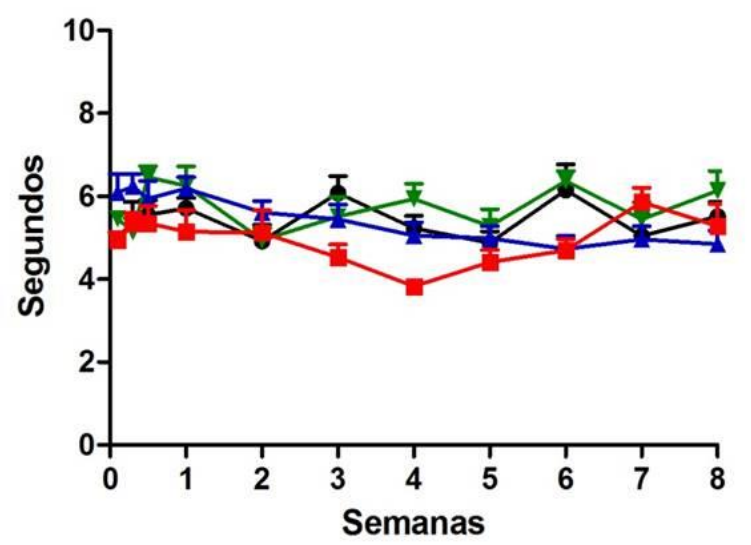

B

Filamentos de Von Frey

Patas Posteriores

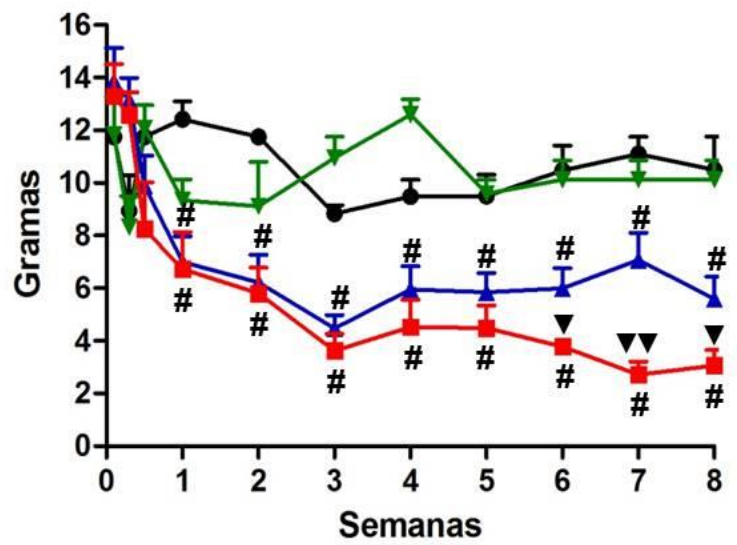

—- Controle
— Laminectomia
— Lesão Leve
- Lesão Moderada

Figura 9: Avaliação da sensibilidade e o estabelecimento da alodínia mecânica nas patas traseiras. Em (A), não foi observado alteração na sensibilidade aos filamentos de von Frey nas patas dianteiras. Em (B), diminuição drástica no limiar para a estimulação com filamentos de von Frey nas patas traseiras, significando alodínia mecânica, que foi notada logo após a $1^{\text {a }}$ semana e persistiu até a $8^{\underline{a}}$ semana. Nota-se que a intensidade da alodínia mecânica foi mais acentuada no grupo lesão moderada (LM) comparado ao grupo lesão leve (LL), em especial na $6^{\underline{a}}, 7^{\mathfrak{a}}, 8^{\mathrm{a}}$ semana. Em (C), nenhuma diferença no limiar nociceptivo foi observado entre os grupos experimentais, como observado pelo teste de retirada da cauda. Kruskal-Wallis seguido pelo pós-teste de Dunns: \#p<0,01 para $L L$ e $L M$ vs grupo controle; $\boldsymbol{\nabla} p<0,05$ e $\boldsymbol{\nabla} \nabla p<0,01$ para LL vs LM. 


\subsubsection{Imunofluorescência/Imunohistoquímica}

A análise morfológica através marcação tecidual por HE mostrou uma lesão menos extensa no grupo LL, cerca de $0,56 \mathrm{~cm}$, quando comparado com o grupo LM, o qual teve uma lesão de aproximadamente $0,65 \mathrm{~cm}(p<0,01$; figura 10). Em relação à quantificação de NeuN na substância cinzenta da medula espinal, observamos uma grande diminuição no número de neurônios na área da lesão de ambos os grupos com lesão medular comparados com os grupos laminectomia e controle $(p<0,001)$, ainda, a população neuronal no grupo LM representou aproximadamente metade da população contada no grupo LL $(p<0,001)$. Nos níveis acima e abaixo da área da lesão não foi observada diferenças entre os grupos experimentais (figura 11).
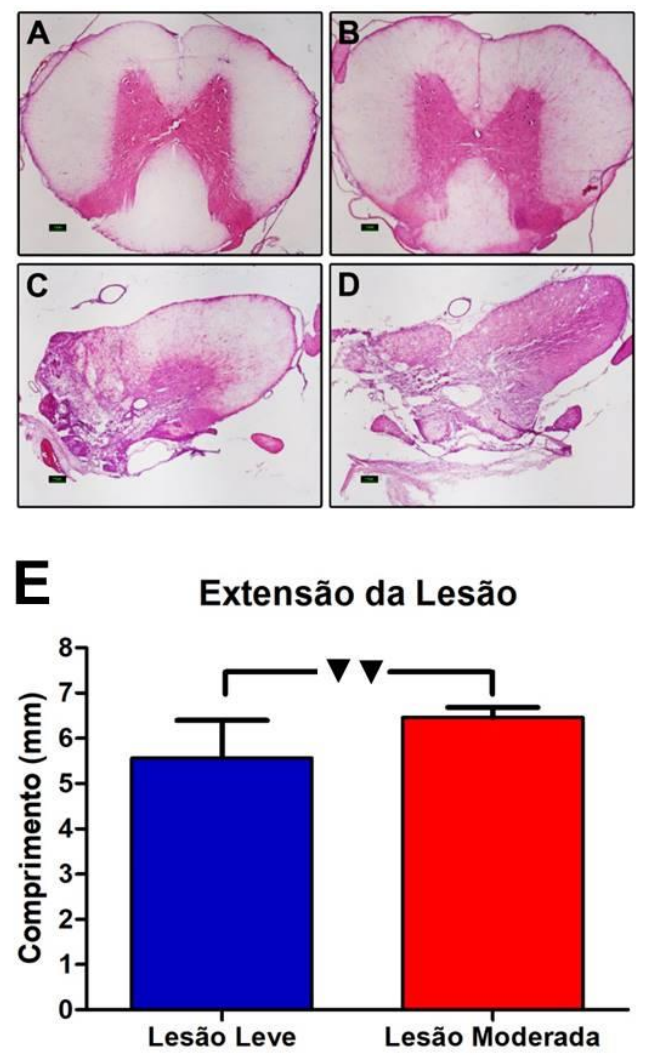

Figura 10: Quantificação da extensão da lesão medular através da coloração com hematoxilina-eosina. As imagens mostram secções da área da lesão dos grupos controle (A), laminectomia (B), lesão leve (C) e lesão moderada (D). Teste de Mann-Whitney: $\nabla \nabla p<0,001$. Barra de Escala: $10 \mu \mathrm{m}$. 

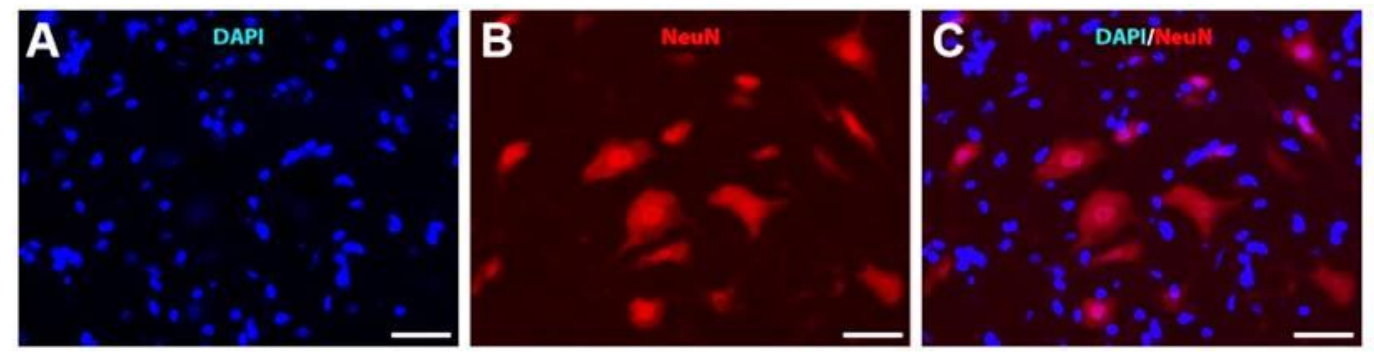

\section{Contagem de Células}

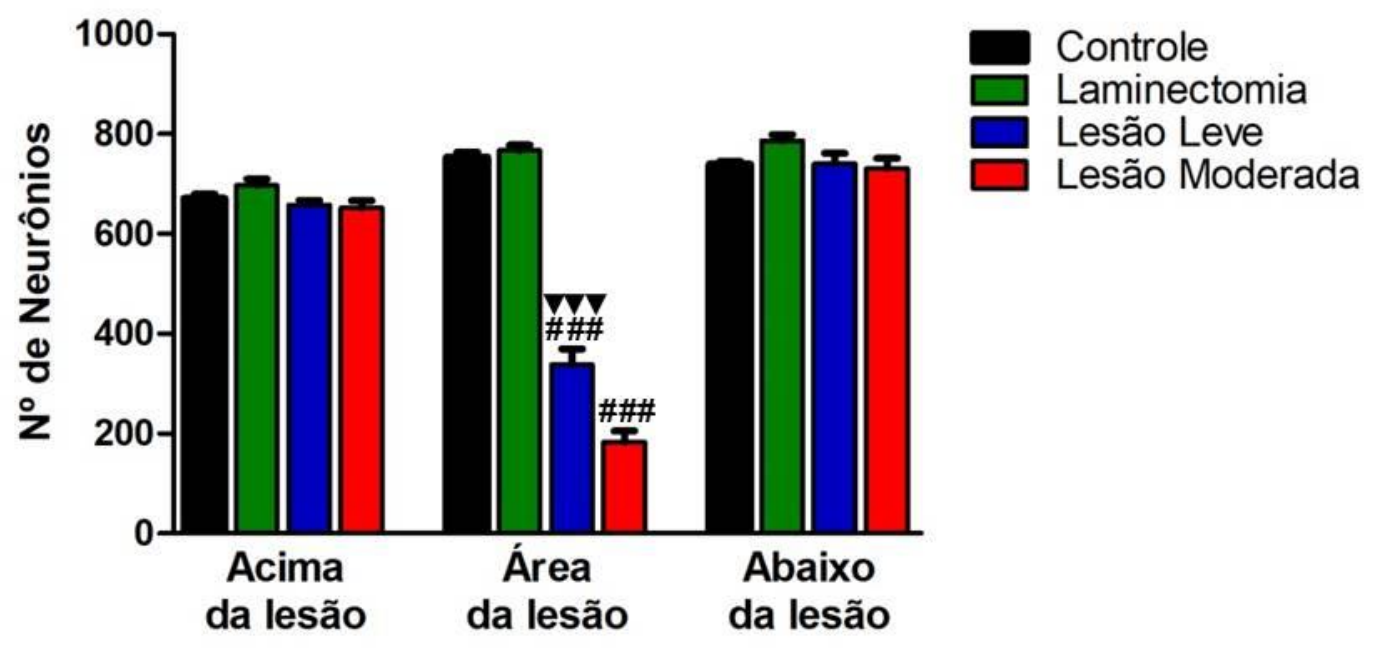

Figura 11: Quantificação estereológica de neurônios neuN positivos. Em (A-C), coloração típica de DAPI e NeuN na substância cinzenta da medula espinal em uma região não lesionada. Em (D), resultado da quantificação em seções acima, abaixo e na área da lesão. Kruskal-Wallis seguido pelo pós-teste de Dunns: $\# \# \# p<0,001$ quando os grupos lesão leve (LL) e lesão moderada (LM) diferem dos grupos controle e laminectomia; $\nabla \nabla \nabla p<0,001$ quando o grupo LL difere do grupo LM. Barra de Escala: $200 \mu \mathrm{m}$.

\subsection{Resultados do Projeto Principal}

\subsubsection{Análise da Sobrevivência e do Peso Corporal}

Parte dos animais de todos os grupos vieram a falecer em consequência da imunossupressão, durante o período de 8 semanas de observação. Nenhuma diferença estatística foi observada entre os grupos (figura 12, A). Em relação ao ganho de peso, todos os animais submetidos à lesão medular traumática tiveram 
uma diminuição do seu peso corporal após o trauma, com um aumento gradativo ao longo das semanas seguintes (figura 12, B).
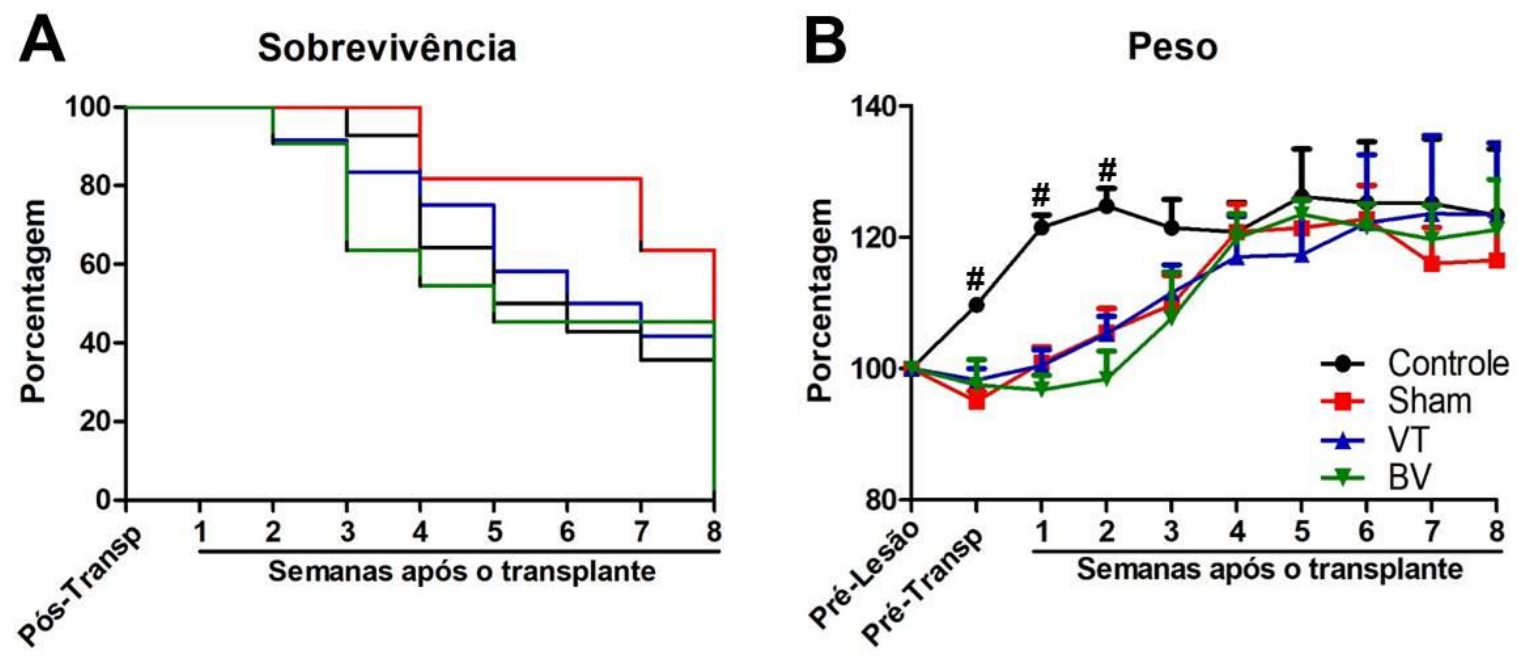

Figura 12: Avaliação da sobrevivência e ganho de peso. (A) Curva de sobrevivência de Kaplan-Meier e (B) ganho do peso corporal dos animais do grupo controle, sham, vesícula telencefálica (VT) e bulbo ventral (BV) após lesão medular e imunossupressão. Kruskal-Wallis seguido pelo pós-teste de Dunns: $\# p<0,01$ quando os grupos sham, VT e BV diferem do controle.

\subsubsection{Avaliação Motora}

A avaliação locomotora, através da escala BBB, mostrou uma discreta melhora espontânea de todos os grupos submetidos à lesão medular durante o período avaliado, porém não foram observadas diferenças significativas entre os grupos tratados em relação ao grupo sham (figura 13, A). De forma similar, o teste plano inclinado demonstrou perda significativa de força e resistência muscular nos animais submetidos à lesão medular traumática, com recuperação parcial ao longo do período avaliado, sem diferenças entre os grupos tratados e o grupo sham (figura 13, B). 
Por fim, a avaliação do desempenho motor realizado através do monitor de atividades mostrou uma diminuição da distância percorrida, da velocidade e da quantidade de levantamento (apoio bipodal) em todos os animais que foram submetidos à lesão medular, tratados e não tratados. Ademais, houve uma diminuição do desempenho motor dos animais do grupo controle ao longo do período avaliado (figura 14).

A

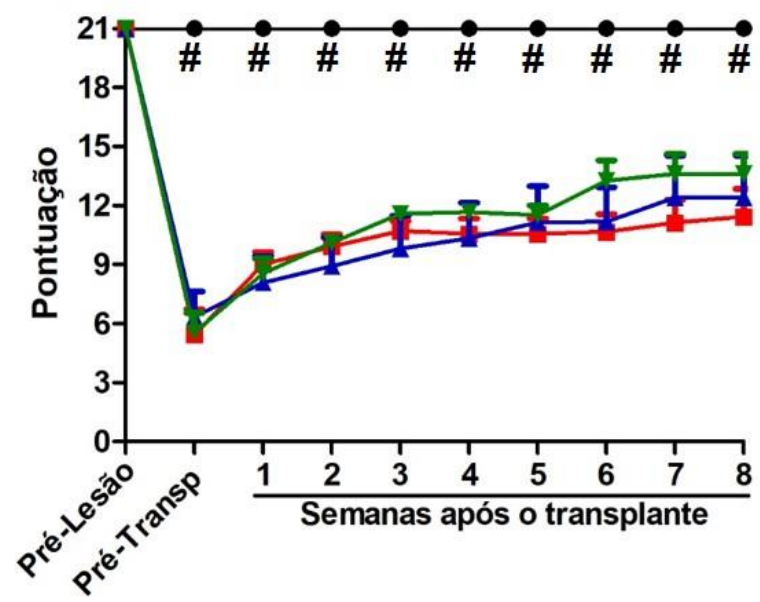

B

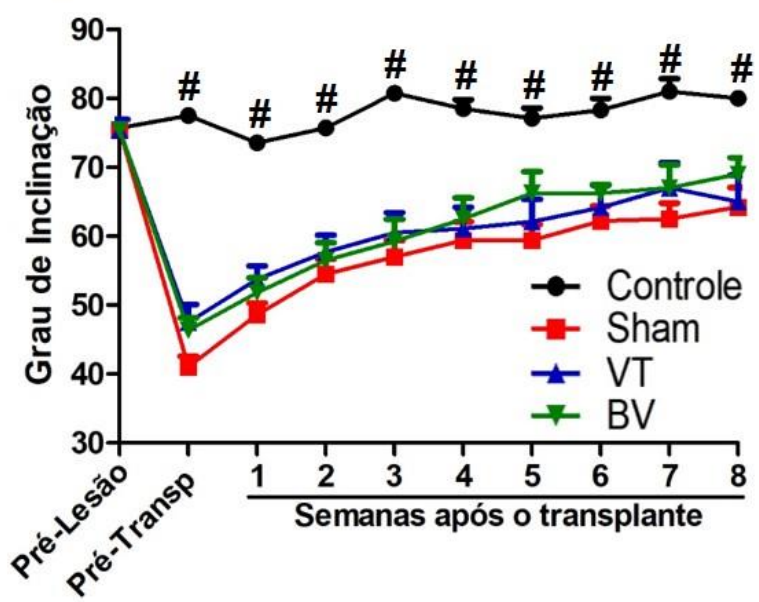

Figura 13: Avaliação da função motora. A função locomotora bem como a força $e$ resistência muscular dos animais foi avaliado através dos testes BBB $(A)$ e plano inclinado (B). Apesar de uma discreta melhora espontânea, não foram observadas diferenças significantes entre os grupos vesículas telencefálicas (VT) e bulbo ventral (BV) em relação ao grupo sham. Teste de Kruskal-Wallis seguido pelo pós-teste de Dunn: $\# p<0,05$ quando os grupos sham, VT e BV diferem do grupo controle. 


\section{A Distância Percorrida}

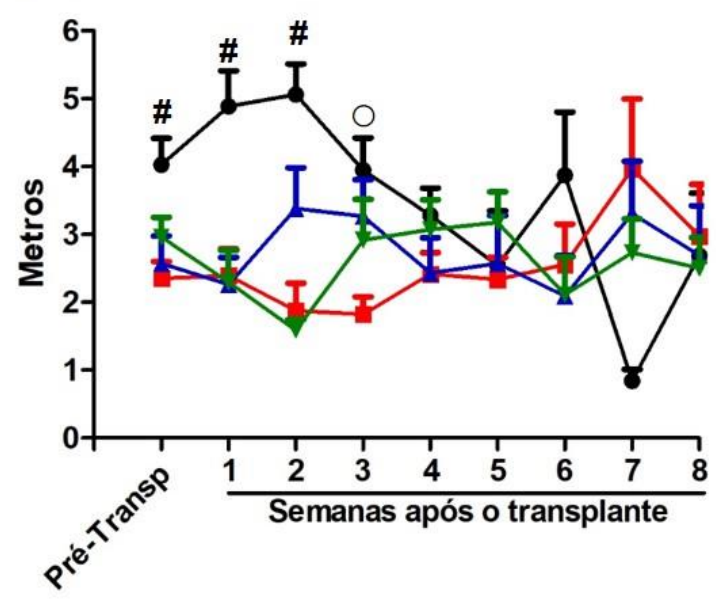

\section{Apoio Bipodal}

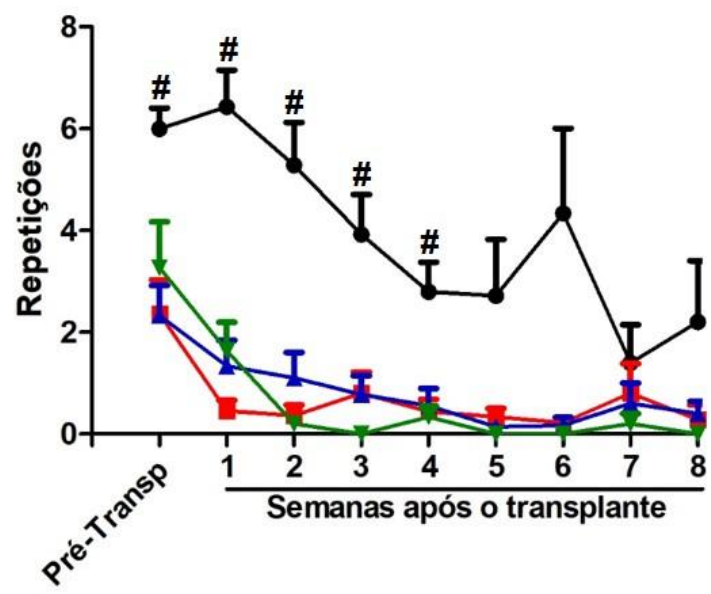

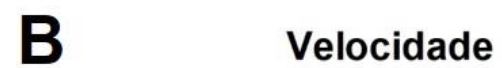

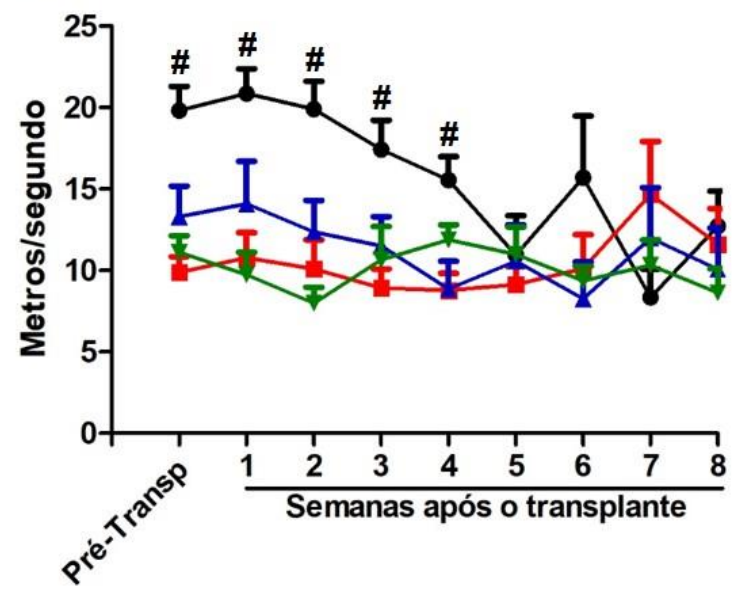

$\rightarrow$ Controle
$\rightarrow$ Sham
$\neq$ VT
$\neq$ BV

Figura 14: Avaliação do desempenho motor através do monitor de atividades. (A) representa a distância percorrida, (B) a velocidade da marcha e (C) a quantidade de vezes que o animal ficou em apoio bipodal. Teste de Kruskal-Wallis seguido pelo pós-teste de Dunn: \#p<0,05 quando os grupos sham, vesícula telencefálica (VT) e bulbo ventral (BV) diferem do grupo controle e op<0,05 quando apenas o grupo sham difere do grupo controle. 


\subsubsection{Avaliação Sensitiva}

Em relação à alodínea mecânica, avaliada pelos filamentos de von Frey, não foi observado nenhuma diferença nas patas anteriores entre os grupos experimentais (figura 15, A). Por sua vez, houve uma diminuição do limiar sensitivo para estímulos mecânicos nas patas traseiras de todos os grupos submetidos à lesão medular quando comparados ao grupo controle (figura 15, B). Ademais, foi observado uma melhora da alodínia mecanica nos grupos VT e BV em relação ao grupo sham na $8^{\circ}$ semana de avaliação (VT vs sham $p<0,05$; BV vs sham $p<0,01)$.

De forma similar, o teste placa quente mostrou uma diminuição do limiar sensitivo para estímulo térmico em todos os grupos submetidos à lesão medular, no entanto, os grupos VT e BV diferiram significativamente em relação ao grupo sham (figura 15, C). $\mathrm{Na} 5^{\underline{a}}, 7^{\underline{a}}$ e $8^{\underline{a}}$ semana pós-transplante, o grupo VT apresentou melhor estado funcional em relação ao grupo sham $\left(p<0,05\right.$ na $5^{\text {a }}$ e $7^{\underline{a}}$ semana, $p<0,01$ na $8^{\underline{a}}$ semana) e na $4^{\underline{a}}, 5^{\underline{a}}, 7^{\underline{a}}$ e $8^{\underline{a}}$ semana pós-transplante transplante o grupo BV apresentou melhor desempenho $\left(p<0,01\right.$ na $4^{\underline{a}}, 5^{\underline{a}}$ e $7^{\underline{a}}$ semana; $p<0,001$ na 8aㅗ semana) em relação ao sham. 
A Filamentos de Von Frey Patas Anteriores

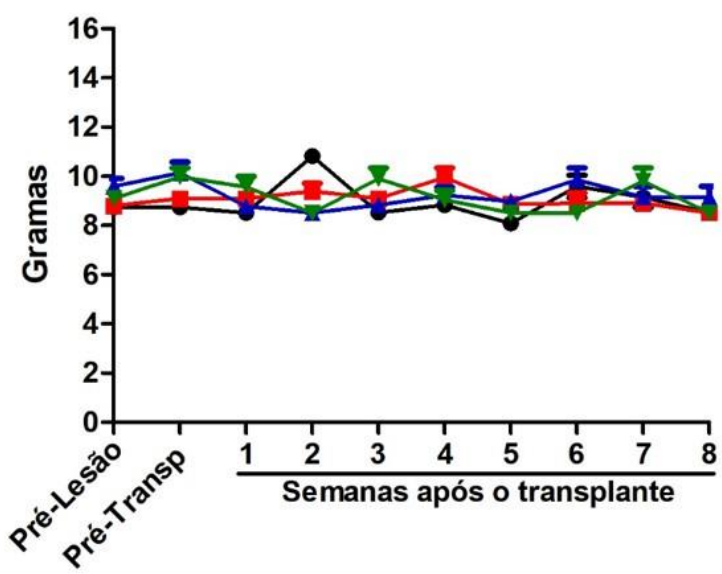

C

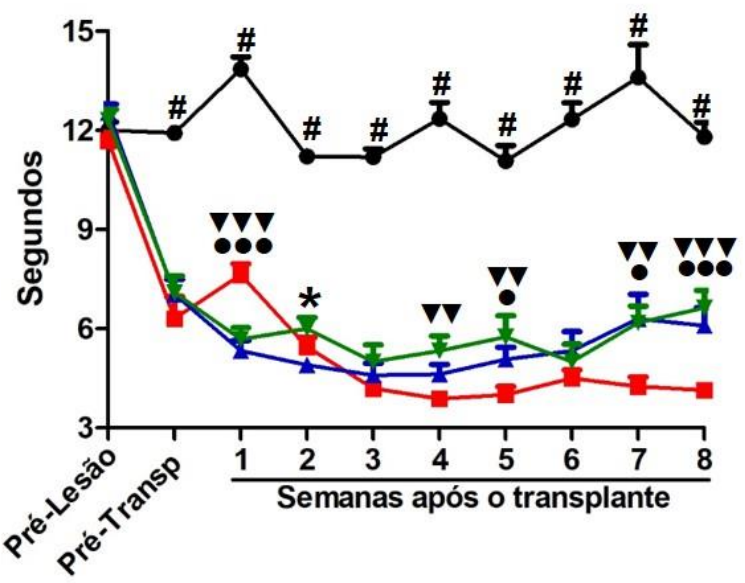

B Filamentos de Von Frey Patas Posteriores

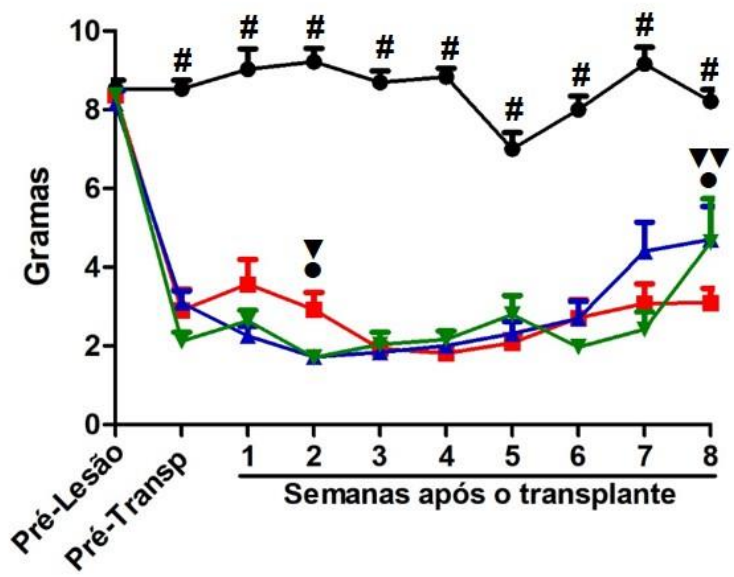

$\rightarrow$ Controle
$\rightarrow$ Sham
\pm VT
$\rightarrow$ BV

Figura 15: Melhora da alodínia mecânica e da hiperalgesia térmica nos grupos tratados com células tronco neurais fetais. Em (A) nenhuma diferença entre os grupos experimentais foi observada nas patas dianteiras em resposta ao estímulo com filamentos de von Frey. Em (B), melhora da alodínia mecânica nas patas traseiras dos animais do grupo vesículas telencefálicas (VT, $\bullet p<0,05$; teste de Mann Whitney) e no grupo bulbo ventral (BV, $\nabla \nabla p<0,01$; teste de Mann Whitney) em comparação com o grupo sham na $8^{\text {a }}$ semana. Em (C), melhora da hiperalgesia térmica na $5^{\mathrm{a}}, 7^{\mathrm{a}}$ e $8^{\mathrm{a}}$ semana no grupo VT $(\bullet p<0,05 ; \bullet \bullet \bullet<<0,05$; teste de Mann Whitney) e na $4^{\mathrm{a}}, 5^{\mathrm{a}}, 7^{\mathrm{a}}$ e $8^{\mathrm{a}}$ semana no grupo BV $(\boldsymbol{\nabla} \boldsymbol{\nabla} p<0.01$, $\boldsymbol{\nabla} \nabla \nabla p<0.001$; teste de Mann Whitney) em relação ao sham. Teste KruskalWallis seguido pelo pós-teste de Dunn: \#p<0,05 quando os grupos sham, VT e BV diferem do grupo controle. 


\subsubsection{Imunofluorescência e Quantificação Estereológica}

A imunofluorescência revelou sobrevivencia e maturação das células progenitoras na medula lesada. De fato, foi observada marcação positiva para NeuN, GFAP, oligodendrócito, GABA, 5HT e encefalina no intervalo de 2 meses após o transplante.

A quantificação estereológica das células transplantadas mostrou que 69\% das células VT e $72 \%$ das células BV se diferenciaram em neurônios maduros, positivamente marcados para NeuN. Ainda, uma porcentagem menor de células foi imuno-positiva para GFAP (10\% das células VT e 23\% das células BV) e para oligodendrócitos ( $23 \%$ das células VT e $26 \%$ de células BV). A contagem também revelou uma proporção maior de células GABAérgicas no grupo VT em comparação com o grupo BV (29\% das células VT e 19\% das células BV, que corresponde a $42 \%$ e $26 \%$ de todas as células neuronais, respectivamente, $p$ $<0,05)$ e uma alta proporção de células serotoninérgicas no grupo BV em comparação com o grupo VT (34\% das células BV e 10\% das células VT, que corresponde a $47 \%$ e $14 \%$ de todas as células neuronais, respectivamente, $p$ $<0,001)$. Uma parte das células de ambos os grupos também foram imuno positivas para encefalina ( $31 \%$ das células VT e $36 \%$ das BV, que corresponde a $44 \%$ e $50 \%$ de todas as células neuronais, respectivamente), porém não houve diferença estatística significativa entre os grupos (figura 16, 17 e 18). 


\section{Estereologia}

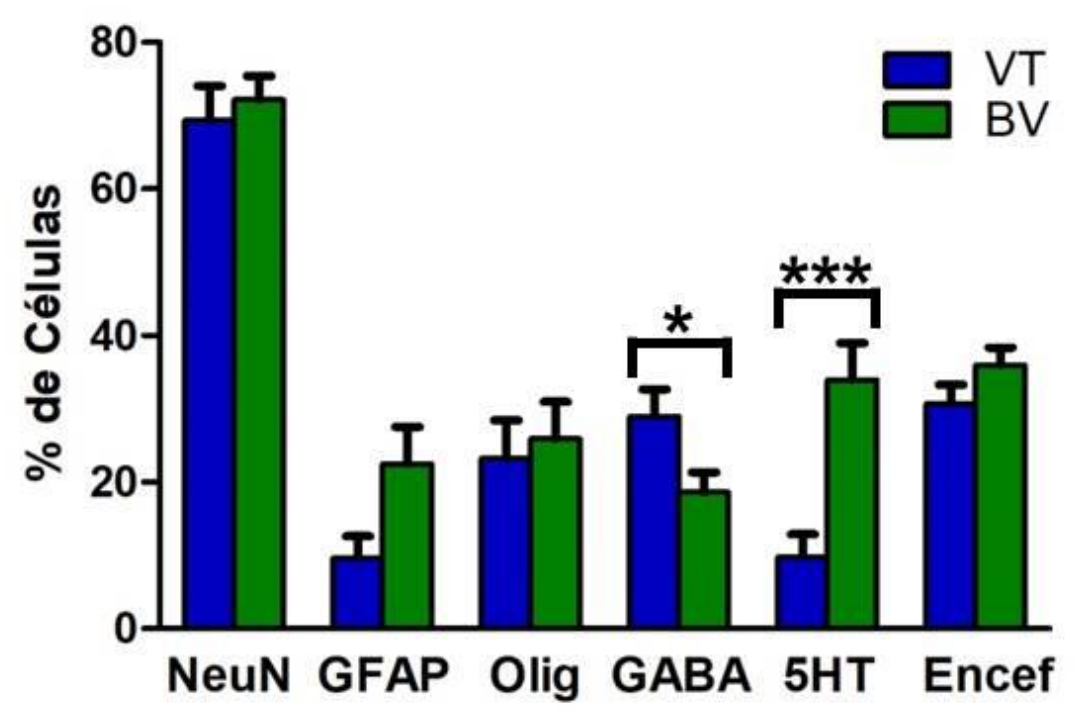

Figura 16: Quantificação estereológica das células transplantadas na medula espinal. As células foram duplamente marcadas com BrdU e NeuN, GFAP, oligodendrócito, GABA, $5 \mathrm{HT}$ e encefalina. A maior parte das células extraídas das vesículas telencefálicas (VT) e do bulbo ventral (BV) se diferenciaram em neurônios, ainda, uma maior porcentagem de células gabaérgicas foi observado no grupo VT e uma maior porcentagem de células serotoninérgicas foi observado no grupo BV. Teste de Mann-Whitney: ${ }^{*} p<0,05$ e ${ }^{* *} p<0,001$. 

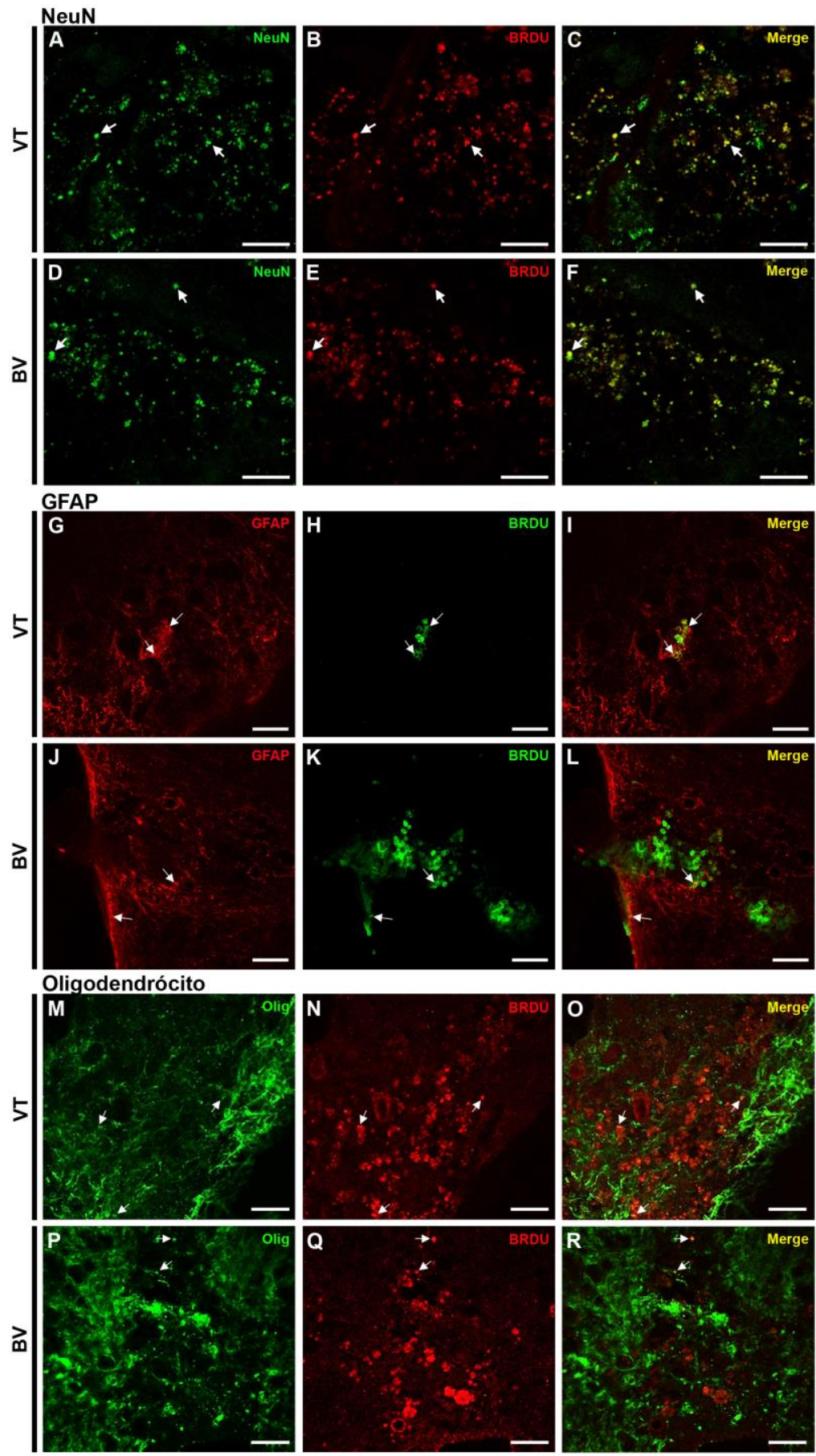

Figura 17: Fotomicrografias mostrando a diferenciação celular das células extraídas das vesículas telencefálicas (VT) e do bulbo ventral (BV) após o transplante da medula espinal lesada. (A-C) Imunofluorescência (IF) de duas cores de NeuN (verde) e BrdU (vermelho) do grupo VT. (D-F) IF de duas cores de NeuN (verde) e BrdU (vermelho) do grupo BV. (G-I) IF de duas cores de GFAP (vermelho) e BrdU (verde) do grupo VT. (J-L) IF de duas cores de GFAP (vermelho) e BrdU (verde) do grupo BV. (M-O) IF de duas cores de oligodendrócito (verde) e BrdU (vermeho) do grupo de TV. (P-R) IF de duas cores de oligodendrócito (verde) e BrdU (vermelho) do grupo BV. As setas indicam as colocalizações. Barra de escala $=50 \mu \mathrm{m}$. 

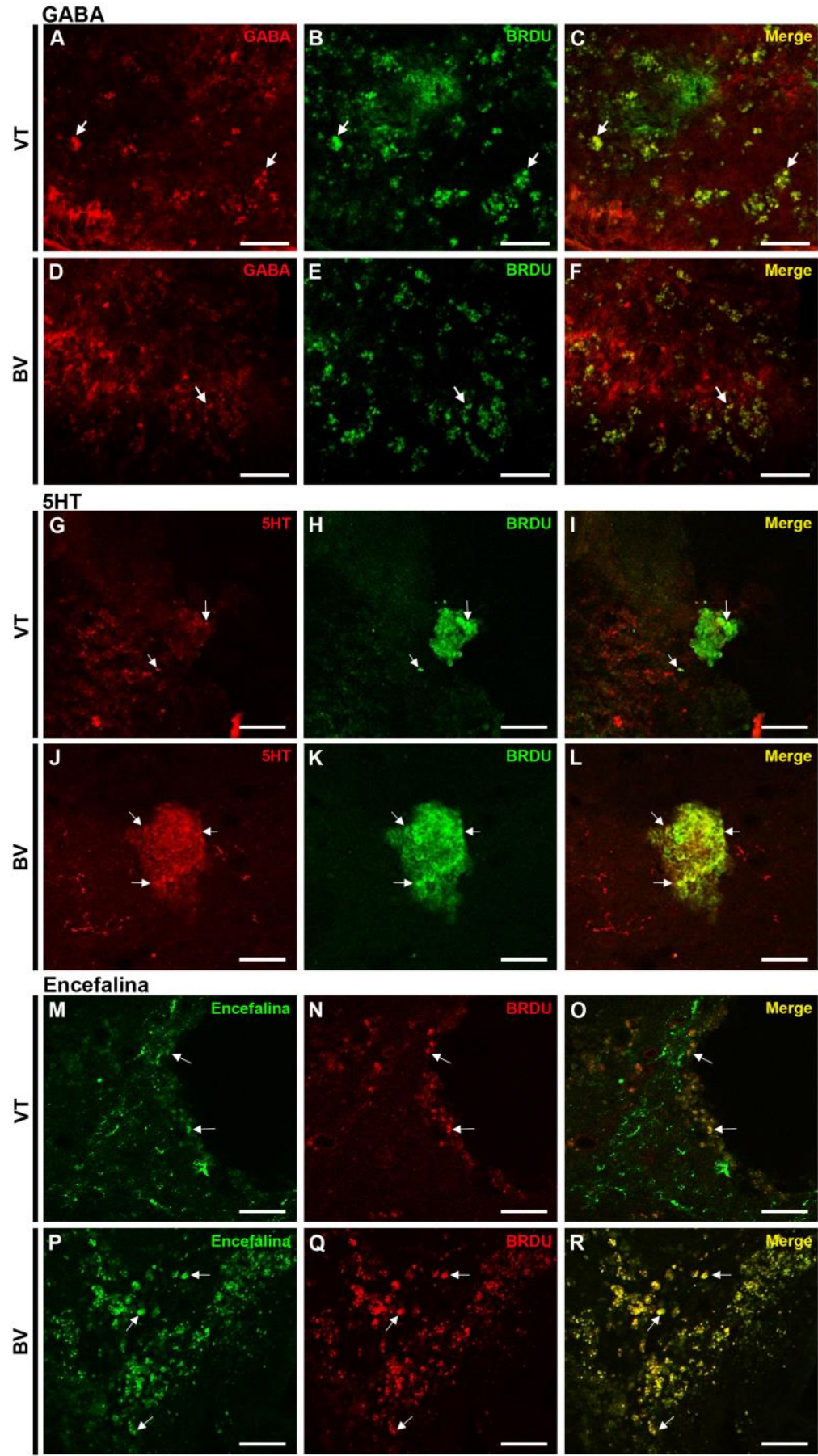

Figura 18: Fotomicrografias mostrando a diferenciação celular das células extraídas das vesículas telencefálicas (VT) e do bulbo ventral (BV) após o transplante da medula espinal lesada. (A-C) Imunofluorescência (IF) de duas cores de GABA (vermelho) e BrdU (verde) do grupo VT. (D-F) IF de duas cores de GABA (vermelho) e BrdU (verde) do grupo BV. (G-I) IF de duas cores de 5HT (vermelho) e BrdU (verde) do grupo VT. (J-L) IF de duas cores de 5HT (vermelho) e BrdU (verde) do grupo BV. (M-O) IF de duas cores de encefalina (vermelho) e BrdU (verde) do grupo de TV. (P-R) IF de duas cores de encefalina (vermelho) e BrdU (verde) do grupo BV. As setas indicam as colocalizações. Barra de escala = $50 \mu \mathrm{m}$. 
DISCUSSÃO 


\section{DISCUSSÃO}

\subsection{Projeto Piloto}

A utilização de modelos experimentais é fundamental para uma maior compreensão da fisiopatologia das doenças de maior interesse e, consequentemente, para o desenvolvimento de novas terapias. Vários modelos animais têm sido utilizados na tentativa de compreender melhor as mudanças que ocorrem após a lesão da medula espinal, bem como para desenvolver estratégias focadas no reparo da região e melhora da motricidade. Recentemente, esses modelos têm sido utilizados para estudar a dor crônica após a lesão medular, no entanto, apesar do aumento do número de estudos, faz-se necessário um maior aprofundamento na área.

Em 1978, Rivlin e Tator desenvolveram uma técnica de compressão usando um clipe vascular para recriar a pressão contínua que frequentemente ocorre após a lesão medular (Rivlin e Tator, 1978). O procedimento envolve uma laminectomia no nível desejado da coluna vertebral, depois disso o clipe é fechado em forças que variam de $35 \mathrm{~g}$ (moderada) a $50 \mathrm{~g}$ (grave) ao redor da medula espinal por períodos variados, produzindo uma lesão aguda. A força e a duração da aplicação do clipe podem produzir lesões graduadas na medula espinal em termos de resultados funcionais e histológicos (Poon et al., 2007). Quando a medula espinal torácica é comprimida em $35 \mathrm{~g}$ ou $50 \mathrm{~g}$, resulta em uma alodínia tátil e hiperalgesia nos membros posteriores, observada até a 4ํㅗ semana após a lesão (Bruce et al., 2002). As vantagens da compressão por clipe incluem uma variação da gravidade da lesão medular e é adaptável para uso em todas as 
regiões da medula espinal, no entanto, o clipe sempre tem que ser calibrado, tendo em vista que a força efetiva de compressão já se altera significativamente após um ou dois fechamentos; além disso, a velocidade de fechamento do clipe sobre medula espinal não é controlada.

Outro modelo de compressão da medula espinal é através da inserção de um cateter de Fogarty (com um pequeno balão fixado em sua ponta) no espaço epidural ou subdural (Vanicky et al., 2001). Após a laminectomia, o balão é posicionado e preenchido com um volume fixo de solução salina ou ar, para comprimir a medula espinal, e é esvaziado após um tempo específico. Dessa forma, a lesão pode ser graduada de acordo com a variação do volume de inflação, duração da compressão ou ambos. Semelhante à compressão utilizando o clipe, este modelo resulta em uma lesão medular de gravidades variáveis e requer uma preparação cirúrgica mínima. No entanto, a compressão do balão normalmente não possui o componente agudo da lesão medular e pode ser bastante difícil padronizar o dano inicial sem monitorar a pressão e a rapidez da insuflação do balão. (Cheriyan et al., 2014). Até onde sabemos, a eficiência em gerar dor duradoura usando esse modelo ainda não está clara.

Modelos de transecção têm sido amplamente utilizados para estudar a regeneração neuronal e subsequente recuperação funcional após lesão. A transecção completa resulta em uma dissociação completa entre os segmentos caudal e rostral, além disso, tem a vantagem de ser facilmente reproduzida. Uma variante envolve a hemisecção da medula espinal. Este modelo tem a vantagem de comparar o lado seccionado com o lado preservado contralateral, bem como examinar a função sensorial e motora em diferentes tratos espinais. Poucos 
trabalhos abordaram a dor usando este modelo; alguns autores descreveram a dor neuropática no nível e abaixo do nível da lesão cinco semanas após a transecção (Scheifer et al., 2002; Densmore et al., 2010). No entanto, hemiseções causam lesões inconsistentes devido à rotação da medula espinal no canal vertebral e variações anatômicas entre os indivíduos. Além disso, no cenário clínico, as lesões de transecção da medula espinal são de longe muito menos comuns do que as de compressão causadas por fraturas (Kwon et al., 2002; Cheriyan et al., 2014).

Por sua vez, o modelo de contusão da medula espinal é o que mais se assemelha à fisiopatologia envolvida na maioria das lesões medulares em humanos (Bunge et al., 1993; Bunge, 1994). O aparelho de contusão da medula espinal em roedores mais comumente usado é o Impactor da Universidade de Nova York (NYU), descrito pela primeira vez por Gruner em 1992 (Gruner, 1992). Após a laminectomia, os processos espinhosos das vértebras acima e abaixo da lesão são fixados por grampos para estabilizar a coluna vertebral durante o impacto. Uma haste de $10 \mathrm{~g}$ é solta de alturas de 6,25, 12,5, 25 e 50mm na superfície dorsal da medula espinal exposta em T9-T10, sendo o dano neurológico causado diretamente proporcional à altura da queda do peso. $\mathrm{NYU}$ Impactor produz uma lesão medular contusa validada e reprodutível. Além da disfunção motora, sensações anormais por estímulos mecânicos ou térmicos (quentes ou frios) são observadas após o trauma (Siddall et al., 1995; Hulsebosch et al., 2000; Ahmed et al., 2014). No entanto, pouco se sabe sobre a persistência da dor sob este método, ou sobre a intensidade da dor induzida nas diferentes alturas possíveis. 
Com base nisso, o objetivo do piloto foi determinar quais variáveis influenciam a geração e a persistência da dor. A lesão grave produzida pela altura da haste de $50 \mathrm{~mm}$ foi excluída do presente estudo devido à alta mortalidade dos animais, automutilação, aumento do risco de infecção urinária, além do quadro de parapleglia completa, a qual prejudica a mensuração da dor (Gruner, 1992). As avaliações do grupo LL mostraram uma recuperação motora espontânea parcial ao longo de todo período estudado, uma recuperação vesical completa 7-8 dias após a lesão medular e, em relação à alodínia mecânica, houve uma piora até a $3^{\text {a }}$ semana pós-lesão e depois desse período os animais apresentaram uma melhora espontânea parcial. Em relação ao grupo LM, as avaliações mostraram uma leve recuperação motora espontânea nas três primeiras semanas após a lesão, atingindo um platô a partir de então (confirmando que os déficits motores estão intimamente relacionados à intensidade da lesão), uma recuperação vesical completa ao final de duas semanas após a lesão e, em relação alodínia mecânica, os animais apresentaram uma deterioração progressiva até o final do período avaliado. A avaliação do limiar nociceptivo, através do teste retirada de cauda, não mostrou diferenças entre os grupos experimentais. Possivelmente, o tempo de reação na retirada da cauda não diferiu entre os grupos com lesão em relação ao grupo controle porque a representação da cauda na medula espinal está longe do local da lesão (T9-T10; 0,5-0,65 cm de extensão), permitindo a recuperação completa dos reflexos medulares neste nível distal.

Tanto a dor espontânea quanto a evocada podem ser causadas por circuitos remanescentes da medula espinal, em regiões craniais e caudais e em porções intactas adjacentes ao local da lesão (Christensen et al., 1996; 
Christensen e Hulsebosch, 1997). Em termos de ocorrência de dor, nossos resultados mostram que as perdas neuronais acima de 50\% parecem ser suficientes para o estabelecimento da dor neuropática.

Os resultados do piloto sugerem que a lesão medular traumática de intensidade moderada é um modelo confiável e reprodutivo para investigar a dor neuropática secundária à lesão medular. Além do déficit motor, o grupo lesão moderada apresentou quadro doloroso progressivo e duradouro, cuja avaliação não foi prejudicada pela gravidade dos déficits motores. Além disso, as alterações sensoriais permaneceram estáveis por pelo menos oito semanas, oferecendo tempo suficiente para manipulações experimentais visando o controle da dor.

\subsection{Projeto Principal}

Uma vez definido o melhor modelo animal para o estudo da dor neuropática causada pela lesão medular, foi iniciado o projeto propriamente dito. Para tal, ratos Wistar foram submetidos à lesão medular traumática de intensidade moderada utilizando o NYU Impactor e, em seguida, os animais foram imunossuprimidos com ciclosporina e tratados com injeção intramedular de CTNfs, utilizando técnica de microtransplante já previamente descrita pelo nosso grupo (Lepski et al., 2011).

O uso de terapia imunossupressora para o transplante de células tronco fetais/embrionárias já foi alvo de grande discussão, pois a hipótese de que células tronco sejam imunologicamente inertes não se confirmou em estudos de viabilidade do transplante. Atualmente, sabemos que a imunossupressão possui um papel importante para a sobrevivência destas células no tecido hospedeiro. 
Para esclarecer essa questão, Swijinburg (Swijnenburg et al., 2008) transplantou em camundongos células tronco embrionárias humanas (CTEh) transduzidas com um gene repórter que consiste da fusão dupla de luciferase e GFP, permitindo o rastreamento destas células in vivo e ex vivo. $O$ autor mostrou que a sobrevivência destas células após o transplante é significativamente limitada em camundongos imunocompetentes em oposição aos imunodeficientes. Ademais, o transplante sequencial de CTEh nos camundongos imunocompetentes resultou em morte acelerada das CTEh, sugerindo ativação de uma resposta imune doador específica. Por fim, demonstrou-se que as CTEh desencadeiam respostas imunes celulares e humorais robustas, resultando em infiltração de células inflamatórias intraenxerto e subsequente rejeição das CTEh. Desta forma, tendo em vista que o processo de morte das células transplantadas pode ser atenuado por um regime imunossupressor, os animais do presente estudo foram submetidos à injeção peritoneal diária de ciclosporina, iniciando três dias antes do transplante e mantido até o final do experimento. Apesar da importância da imunossupressão para a sobrevivência das CTNf, aparentemente a ciclosporina teve um papel determinante na debilidade e consequentemente no óbito de alguns animais, incluindo o grupo controle que não havia sido submetido à lesão medular. Essa complicação foi computada inicialmente e considerada no cálculo de tamanho de amostra necessário para o estudo proposto.

A terapia celular representa uma alternativa promissora no tratamento de lesões do SNC. Na lesão medular traumática, diversos estudos mostram que o transplante de células tronco é capaz de promover a regeneração axonal e 
alguma recuperação funcional (Li e Lepski, 2013), no entanto, pouco se sabe sobre o benefício dessas células para o tratamento contra dor neuropática.

Cada tipo de célula tronco candidata apresenta vantagens e desvantagens em relação à regeneração da medula espinal. Células tronco mesenquimais (CTMs) têm sido descritas como capazes de modular a resposta imune/inflamatória (Kim e Park, 2017), a qual poderia ter um efeito benéfico na dor neuropática induzida pela lesão medular. Rho (Roh et al., 2013) investigou o efeito terapêutico das CTMs derivadas do sangue do cordão umbilical humano (CTM-SCUh) e do transplante de células tronco epiteliais amnióticas (CTEAs) na dor crônica central. As células foram transplantadas ao redor do local da lesão duas semanas após a hemisecção da medula espinal. Apenas o transplante de CTEAs resultou em uma redução significativa da alodínia mecânica e nenhuma das células (CTM-SCUh ou CTEAs) tiveram qualquer efeito na hiperalgesia térmica. O transplante de CTM-SCUn e CTEAs reduziram o aumento da expressão do marcador microglial $\mathrm{F} 4 / 80$, além disso, as CTEAs reduziram também o aumento da fosforilação da subunidade NR1 do receptor NMDA (pNR1), que pode estar relacionado com a melhora da alodínia mecânica observada nos animais.

Watanabe (Watanabe et al., 2015) analisou os efeitos do transplante de CTM derivadas da medula óssea (CTM-MO) na hipersensibilidade à dor em camundongos submetidos à lesão medular contusa. O transplante de CTM-MO três dias após a lesão medular resultou em melhora da função motora e alívio da hipersensibilidade à estimulação mecânica e térmica. $O$ autor sugeriu que as CTM-MO reduzem a dor neuropática através de uma variedade de mecanismos 
relacionados, incluindo a preservação neuronal e restauração da barreira hematomedular danificada, mediada pela modulação da atividade da microglia residente na medula e pela atividade e recrutamento de macrófagos hematogênicos.

De forma similar, Yousefifard (Yousefifard et al., 2016) observou uma melhora da alodínia mecânica e hiperalgesia térmica, bem como recuperação motora, em animais submetidos a transplante de CTM derivadas de medula óssea e de cordão umbilical após lesão medular. Ambos os tipos de células sobreviveram no tecido por pelo menos oito semanas e impediram a formação da cavidade, no entanto, a taxa de sobrevivência de das células derivadas do cordão umbilical foi significativamente maior e avaliações eletrofisiológicas mostraram resultados melhores em comparação com as células da medula óssea. As CTMs transduzidas para produzir neurotrofinas também são candidatas para promover o crescimento celular e aliviar a dor crônica após lesão medular. Sete dias após lesão medular contusa, Kumagai (Kumagai et al., 2013) enxertou no epicentro da lesão CTMs ou CTMs geneticamente modificadas para expressar MNTS1, uma multineurotrofina que se liga aos receptores TrkA, TrkB e TrkC e p75 (NTR) ou CTM-MNTS1/p75(-), que se liga principalmente aos receptores Trk. Todos os grupos tratados com CTMs (modificada ou não) tiveram uma redução na inflamação e no tamanho da cavidade cística em comparação com o grupo controle, porém, apenas o transplante de CTM-MNTS1 e CTM-MNTS1/p75(-), mas não as CTMs naïves, promoveram o crescimento axonal e preveniram significativamente a hipersensibilidade cutânea após lesão medular. 
Por outro lado, as células tronco neurais (CTN) têm sido descritas como uma terapia promissora na tentativa de repovoar a medula espinal após a lesão. Essas células possuem a capacidade de se diferenciar em três linhagens neurais, oligodendrócitos, astrócitos e neurônios, e podem ser encontradas no SNC embrionário, neonatal e adulto. Potenciais usos do transplante de CTN na medula espinal lesada incluem a restituição de células danificadas e a ativação de células endógenas para fornecer "auto-reparo" (Gage, 2000).

Um dos desafios em regeneração medular é a característica intrínseca de oligodendrócitos de inibirem o brotamento axonal no sistema nervoso central. $\mathrm{Na}$ tentativa de se superar esse obstáculo, Tao (Tao et al., 2013) demonstrou que o transplante de células progenitoras de oligodendrócitos (OPCs) derivadas de células tronco embrionárias de ratos, 29 dias após lesão medular, melhorou a remielinização e reduziu a alodínia mecânica. Por outro lado, o transplante de astrócitos, ou a diferenciação de CTNs em astrócitos, pode estar relacionado com o aumento da hiperalgesia térmica e alodínia mecânica em animais submetidos à lesão medular. Isso sugere um papel central dos astrócitos em promover sensibilização central à dor, provavelmente mediada por sensibilização sináptica, liberação de agentes pró-inflamatórios e ativação do sistema imune. Hofstetter (Hofstetter et al., 2005) relatou que o transplante de CTNs adultas após a lesão medular melhorou a recuperação motora mas também causou brotamento axonal aberrante associado à alodínia nas patas. No entanto, a transdução de CTNs com neurogenina-2 antes do transplante suprimiu a diferenciação astrocitária das células transplantadas e preveniu a alodínia. Macias (Macias et al., 2006) observou que o transplante de CTN imortalizadas (C17.2), sozinhas ou 
transfectadas com GDNF, após lesão medular, resultou em alodínia térmica e mecânica. O estudo mostrou que as CTNs sobreviveram e se diferenciaram principalmente em astrócitos, porém, diferenças no grau de alodínia foram observadas entre os grupos tratados com transplante de C17.2 e C17.2/GDNF, sugerindo um possível efeito protetor ou analgésico do GDNF na dor neuropática pós-lesão. Em contrapartida, Davies (Davies et al., 2008) demonstrou que diferentes tipos de astrócitos têm diferentes efeitos na dor crônica induzida pela lesão medular. $\mathrm{O}$ transplante de astrócitos derivados de células precursoras gliais tratados com proteína morfogenética óssea-4 promoveu a regeneração axonal e a recuperação funcional e os ratos transplantados não apresentaram síndromes dolorosas. Em contraste, quando essas células foram geradas através da exposição ao fator neurotrófico ciliar agonista gp130, o transplante resultou na falha da regeneração axonal e recuperação funcional, bem como promoveu alodínia mecânica e hiperalgesia térmica duas semanas após a lesão.

Por sua vez, Yao (Yao et al., 2015) mostrou que as CTNs do tecido do hipocampo de embriões de camundongos, uma vez transplantadas na medula espinal após transecção completa, melhoraram a sensibilidade térmica e mecânica dos animais. Além do mais, Luo (Luo et al., 2013) investigou o efeito analgésico do cotransplante de CTNs com células da glia do nervo olfatório (olfactory ensheathing cells - OECs) em ratos submetidos à transecção completa da medula espinal. O transplante de CTNs melhorou a função sensorial nos ratos com lesão medular, enquanto o transplante das OECs resultou em hiperalgesia. Por sua vez, o cotransplante resultou na inversão da hiperalgesia desencadeada pelas OECs e promoveu a sobrevivência das CTNs. 
Levando em consideração as alterações que ocorrem na medula espinal após a lesão que contribuem para o aparecimento da dor neuropática, as células tronco/progenitoras GABAérgicas tornam-se uma forte candidata na tentativa de reverter as respostas dolorosas. Como mencionado anteriormente, vários mecanismos estão relacionados ao aparecimento de dor neuropática induzida pela lesão medular, incluindo a regulação da enzima sintetizadora de GABA que, juntamente com outras alterações, pode resultar na desinibição dos impulsos excitatórios, contribuindo para o efeito da hiperexcitabilidade. (Berrocal et al., 2014).

O grupo de Fandel (Fandel et al., 2016) avaliou os efeitos do transplante de células de eminência ganglionar medial (EGM) derivadas de células tronco embrionárias humanas. Os camundongos foram lesionados no nível segmentar T13 e duas semanas após a lesão as células foram transplantadas na intumescência lombar. Seis meses após o transplante, as células estavam amplamente dispersas na medula espinal lesionada, estendendo-se em torno de 10mm rostro caudal, além do mais, diferenciaram-se em neurônios GABAérgicos e os animais transplantados apresentaram melhora dos sintomas relacionados à dor.

Por sua vez, Hwang (Hwang et al., 2016) observou que células precursoras neurais derivadas de células tronco embrionárias, quando cultivadas em meio suplementado com hedgehog sônico (SHH) e ácido retinóico (RA), diferenciavam de forma eficiente em neurônios GABAérgicos. Ademais, o transplante dessas células após a lesão medular em ratos foi capaz de atenuar a dor neuropática, porem não houve melhora na recuperação motora. 
Nosso protocolo de extração celular (CTNf derivadas das VT de embriões E14) e método de cultura celular também favoreceu a diferenciação de neurônios GABAérgicos. De fato, um estudo prévio de nosso grupo de estudo demontrou que $60 \%$ das células neuronais maduras obtidas do fNSC das vesículas telencefálicas de ratos E14 assumiam um fenótipo GABAérgico (Maciaczyk et al., 2008). Além disso, registros de patch-clamp revelaram que as células maduras obtidas com nosso protocolo apresentavam correntes sinápticas GABAérgicas após 2 semanas in vitro (Lepski et al., 2013). Essas evidências nos levaram a questionar se as células GABAérgicas possuiam algum potencial para tratar a dor após a lesão medular.

No presente estudo, observou-se que as células sobreviveram oito semanas após o transplante e foram encontradas principalmente na periferia da lesão; ademais, $42 \%$ de todas as células neuronais do grupo VT se diferenciaram em neurônios GABAérgicos, como observado pelas análises estereológicas. Além disso, os animais que receberam injeções intraespinais de CTNf da região da VT tiveram uma melhora da alodinia mecânica e da hiperalgesia térmica após a lesão medular.

Adicionalmente, sabe-se que as vias descendentes monoaminérgicas regulam a transmissão de informação nociceptiva na medula espinal. As vias serotoninérgicas descendentes do núcleo da rafe e vias noradrenérgicas descendentes do locus ceruleus atingem a medula espinal e inibem os neurônios de $2^{a}$ ordem das vias da dor, seja por conexões diretas ou interneurônios, na substância gelatinosa de Rolando (Kandel et al., 2012). Assim, hipotetizamos que - transplante de células extraídas da região ventral do metencéfalo e 
mielencéfalo, que futuramente darão origem às regiões da ponte e do bulbo, poderia inibir a transmissão dolorosa após a lesão medular.

As CTNf do BV também sobreviveram oito semanas após o transplante e foram encontradas principalmente na borda da lesão. No entanto, uma maior proporção de células serotoninérgicas foi observada no grupo BV, de fato, $47 \%$ de todas as células neuronais contadas, como mostrado pela análise estereológica. As avaliações sensoriais e motoras foram muito semelhantes em relação ao grupo VT, os animais do grupo BV também apresentaram melhora na alodínia mecânica e hiperalgesia térmica após lesão medular, porém, a diferença estatística quando comparado ao grupo sham foi maior que o grupo VT, indicando maior eficiência desse subtipo celular no controle da dor neuropática no nosso modelo animal. Além disso, nenhuma recuperação motora significativa foi observada em ambos os grupos VT e BV.

O resultado da análise estereológica também mostrou que a extração de CTNf de diferentes regiões do cérebro do embrião E14 foi capaz de gerar neurônios maduros com diferentes fenótipos. Esses eventos podem ser explicados pela teoria da especificação regional embrionária inicial das células tronco neurais pós-natais, como proposto por Fuentealba (Fuentealba et al., 2015). De acordo com esse estudo, a maioria das células tronco/progenitoras neurais adultas produzidas entre os dias embrionários 13,5 e 15,5 permanecem em grande parte quiescentes até serem reativadas no período pós-natal. Ou seja, possivelmente as células extraídas das VT e do BV de embriões com 14 dias de vida intrauterina já possuíam certa especificidade e por isso geraram diferentes tipos de células neuronais após o transplante na medula espinal lesada. 
Apesar do sucesso apresentado no controle da dor, não observamos melhora alguma no padrão motor dos animais transplantados. Isso talvez remeta a uma maior complexidade do sistema motor, ou melhor dizendo, com maior interdependência entre os sistemas envolvidos, organizados em múltiplos níveis desde o cortex associativo aos motoneurônios medulares, com menor susceptibilidade de restauro por meio de intervenções mais focais. Uma manipulação celular eficiente do ponto de vista regenerativo talvez devesse abordar cada um desses segmentos de processamento e de maneira interligada. Por outro lado, a intervenção celular contra dor aqui proposta baseia-se tão somente na inibição local de neurônios de segunda ordem em segmentos medulares deaferentados. Apesar do sistema sensitivo não ser menos complexo que o sistema motor, a intervenção celular aqui proposta é não-fisiológica, local e restrita, visando restaurar o equilíbrio entre excitaçao e inibição numa parte específica do tecido neural hiperexcitado após a lesão. Não se trata de um tipo celular que esteja fisiologicamente presente no local de ação, mas sim uma manipulação artificial restaurando a fisiologia da circuitaria medular. 
CONCLUSÕES 


\section{CONCLUSÕES}

\section{Projeto Piloto}

$\checkmark$ A lesão medular traumática de intensidade moderada aparenta ser um modelo confiável e reprodutível para investigar a dor neuropática central de origem medular. Além do déficit motor, o grupo com lesão moderada apresentou um quadro doloroso progressivo e duradouro, cuja avaliação não foi prejudicada pela gravidade dos déficits motores.

$\checkmark$ Em termos de ocorrência de dor, perdas neuronais acima de $50 \%$ parecem ser suficientes para o estabelecimento da dor neuropática. Ademais, as alterações sensoriais permaneceram estáveis por pelo menos 8 semanas, oferecendo tempo suficiente para manipulações experimentais que visam o controle da dor.

\section{Projeto Principal}

$\checkmark$ As duas populações celulares estudadas (VT e BV) foram capazes de induzir melhora no padrão sensitivo-doloroso após a lesão medular, porém a eficiência da população oriunda do BV foi superior a da VT. No entanto, não se observou melhora motora por meio dos transplantes celulares estudados, possivelmente em decorrência de organização interdependente e "multissegmentar" do sistema motor, que o torna menos susceptível a uma intervenção celular mais localizada e restrita.

$\checkmark$ As células transplantadas foram encontradas principalmente na borda da lesão. Células tronco neurais, sejam da VT ou do BV, isoladas e 
expandidas segundo nosso protocolo geraram alta proporção de células neuronais. Ademais, as células extraídas da VT e do BV foram capazes de gerar diferentes fenótipos maduros, enquanto as células da VT geraram preferencialmente neurônios GABAérgicos e encefalinérgicos, as células do BV se diferenciaram principalmente em neurônios serotoninérgicos e encefalinérgicos, comprovando a teoria de especificação fenotípica de Fuentealba. 
ANEXOS 


\section{ANEXOS}

\subsection{Aprovação do Comitê de Ética}

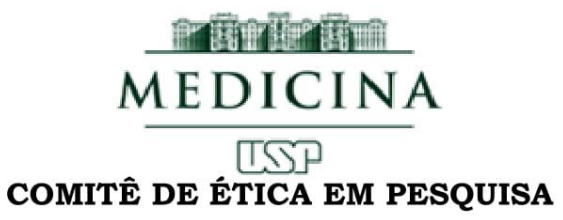

A CEUA do Comitê de Ética em Pesquisa da Faculdade de Medicina da Universidade de São Paulo, em 28/03/2014, APROVOU o Protocolo de Pesquisa $n^{0}$ 033/14 intitulado “Avaliação da dor neuropática e das funções motoras e somato-sensitiva após o transplante de célulastronco em modelo de lesão de medula espinal em ratos" que utilizará 27 animais da espécie ratos, apresentado pelo Departamento de Cirurgia.

Cabe ao pesquisador elaborar e apresentar ao CEP-FMUSP, o relatório final sobre a pesquisa, (Lei Procedimentos para o Uso Científico de Animais - Lei No 11.794-8 de outubro de 2008).

Pesquisador (a) Responsável: Guilherme Alves Lapski

Pesquisador (a) Executante: Chary Ely Martin Marquez Batista

CEP-FMUSP, 28 de Março de 2014.

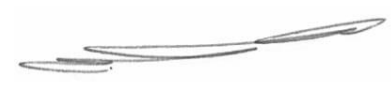

Dr. Eduardo Pompeu

Coordenador

Comissão de Ética no Uso de Animais

$$
\text { Zlheminn. }
$$

Prof. Dr. Roger Chammas

Coordenador

Comitê de Ética em Pesquisa 


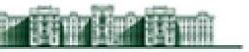 MEDICINA \\ TSP \\ COMISSÃO DE ÉTICA NO USO DE ANIMAIS}

A CEUA da Faculdade de Medicina da Universidade de São Paulo, em 14/o9/16, APROVOU o documento abaixo mencionado, para o Protocolo de Pesquisa no o33/14, intitulado: "Avaliação da dor neuropática e das funções motoras e somato-sensitiva após o transplante de célulastronco em modelo de lesão de medula espinal em ratos", apresentado pelo Departamento de Cirurgia

- Aumento do número de animais para 80 ratos wistar machos

Pesquisador Responsável: Guilherme Alves Lepski

CEUA-FMUSP, 14 de Setembro de 2016

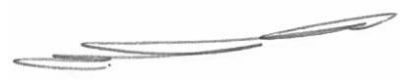

Dr. Eduardo Pompeu

Coordenador

Comissão de Ética no Uso de Animais

Comissão de Ética no Uso de Animais da FMUSP

e-mail: ceua.fm@usp.br 


\subsection{Dados Estatísticos do Projeto Piloto}

Dados referentes às análises do projeto piloto. Os valores estão apresentados como média aritmética \pm erro padrão da média.

\begin{tabular}{|c|c|c|c|c|c|c|c|c|}
\hline \multicolumn{9}{|c|}{ Projeto Piloto - Peso (\%) } \\
\hline & \multicolumn{2}{|r|}{ Controle } & \multicolumn{2}{|r|}{ Sham } & \multicolumn{2}{|r|}{ Lesão Leve } & \multicolumn{2}{|c|}{ Lesão Moderada } \\
\hline Semanas & $\mathbf{N}$ & Média \pm e.p.m. & $\mathbf{N}$ & Média \pm e.p.m. & $\mathbf{N}$ & Média \pm e.p.m. & $\mathbf{N}$ & Média \pm e.p.m. \\
\hline 1 & 5 & $105,7 \pm 0,6$ & 6 & $106,4 \pm 5,2$ & 11 & $91,4 \pm 1,3$ & 8 & $102,5 \pm 3,04$ \\
\hline 2 & 5 & $118,2 \pm 1,4$ & 6 & $119,4 \pm 6,3$ & 11 & $102,5 \pm 1,9$ & 8 & $11,9 \pm 4,1$ \\
\hline 3 & 5 & $127,7 \pm 2,3$ & 6 & $130,0 \pm 7,0$ & 11 & $114,9 \pm 2,6$ & 8 & $121,2 \pm 4,6$ \\
\hline 4 & 5 & $131,5 \pm 2,3$ & 6 & $138,3 \pm 8,0$ & 11 & $120,0 \pm 3,2$ & 8 & $129,8 \pm 4,5$ \\
\hline 5 & 5 & $137,8 \pm 2,5$ & 6 & $144,8 \pm 8,9$ & 11 & $125,9 \pm 3,3$ & 7 & $138,3 \pm 5,6$ \\
\hline 6 & 5 & $143,4 \pm 3,1$ & 6 & $151,8 \pm 9,7$ & 11 & $129,5 \pm 3,4$ & 7 & $143,5 \pm 5,8$ \\
\hline 7 & 5 & $149,1 \pm 2,9$ & 6 & $156,6 \pm 10,1$ & 11 & $135,9 \pm 3,5$ & 7 & $147,5 \pm 6,2$ \\
\hline 8 & 5 & $155,5 \pm 2,7$ & 6 & $161,4 \pm 10,9$ & 11 & $140,0 \pm 3,9$ & 7 & $151,9 \pm 6,3$ \\
\hline
\end{tabular}

Projeto Piloto - Recuperação da Bexiga (\%)

\begin{tabular}{c|c|c|c|c|c|c|c|c}
\hline & \multicolumn{2}{|c|}{ Controle } & \multicolumn{2}{c|}{ Sham } & \multicolumn{2}{c|}{ Lesão Leve } & \multicolumn{2}{c}{ Lesão Moderada } \\
\hline Dias & N & Média \pm e.p.m. & N & Média \pm e.p.m. & N & Média \pm e.p.m. & N & Média \pm e.p.m. \\
\hline 1 & 5 & $100 \pm 0$ & 6 & $100 \pm 0$ & 11 & $38,2 \pm 11,4$ & 8 & $6,2 \pm 6,2$ \\
2 & 5 & $100 \pm 0$ & 6 & $100 \pm 0$ & 11 & $47,7 \pm 11,4$ & 8 & $12,5 \pm 8,2$ \\
3 & 5 & $100 \pm 0$ & 6 & $100 \pm 0$ & 11 & $54,5 \pm 11,6$ & 8 & $12,5 \pm 9,4$ \\
4 & 5 & $100 \pm 0$ & 6 & $100 \pm 0$ & 11 & $65,9 \pm 8,4$ & 8 & $18,7 \pm 10,3$ \\
5 & 5 & $100 \pm 0$ & 6 & $100 \pm 0$ & 11 & $81,8 \pm 9,6$ & 8 & $18,9 \pm 10,2$ \\
6 & 5 & $100 \pm 0$ & 6 & $100 \pm 0$ & 11 & $88,7 \pm 6,2$ & 8 & $53,1 \pm 7,4$ \\
7 & 5 & $100 \pm 0$ & 6 & $100 \pm 0$ & 11 & $95,4 \pm 4,5$ & 8 & $65,7 \pm 11,5$ \\
8 & 5 & $100 \pm 0$ & 6 & $100 \pm 0$ & 11 & $97,7 \pm 2,3$ & 8 & $78,1 \pm 7,4$ \\
9 & 5 & $100 \pm 0$ & 6 & $100 \pm 0$ & 11 & $100 \pm 0$ & 8 & $84,4 \pm 6,6$ \\
10 & 5 & $100 \pm 0$ & 6 & $100 \pm 0$ & 11 & $100 \pm 0$ & 8 & $87,5 \pm 4,7$ \\
11 & 5 & $100 \pm 0$ & 6 & $100 \pm 0$ & 11 & $100 \pm 0$ & 8 & $87,5 \pm 4,7$ \\
12 & 5 & $100 \pm 0$ & 6 & $100 \pm 0$ & 11 & $100 \pm 0$ & 8 & $90,6 \pm 4,6$ \\
13 & 5 & $100 \pm 0$ & 6 & $100 \pm 0$ & 11 & $100 \pm 0$ & 8 & $96,9 \pm 3,1$ \\
14 & 5 & $100 \pm 0$ & 6 & $100 \pm 0$ & 11 & $100 \pm 0$ & 8 & $96,9 \pm 3,1$ \\
\hline
\end{tabular}


Projeto Piloto - BBB

\begin{tabular}{c|c|c|c|c|c|c|c|c}
\hline & \multicolumn{2}{|c|}{ Controle } & \multicolumn{3}{c|}{ Sham } & \multicolumn{2}{c|}{ Lesão Leve } & \multicolumn{2}{c}{ Lesão Moderada } \\
\hline Semanas & N & Média \pm e.p.m. & N & Média \pm e.p.m. & N & Média \pm e.p.m. & N & Média \pm e.p.m. \\
\hline 1 & 5 & $21 \pm 0$ & 6 & $21 \pm 0$ & 11 & $6,5 \pm 1,4$ & 8 & $2,2 \pm 1$ \\
2 & 5 & $21 \pm 0$ & 6 & $21 \pm 0$ & 11 & $10,4 \pm 0,9$ & 7 & $4,6 \pm 1,4$ \\
3 & 5 & $21 \pm 0$ & 6 & $21 \pm 0$ & 11 & $12,1 \pm 1,0$ & 7 & $5,1 \pm 1,5$ \\
4 & 5 & $21 \pm 0$ & 6 & $21 \pm 0$ & 11 & $12,8 \pm 1$ & 7 & $5,6 \pm 1,7$ \\
5 & 5 & $21 \pm 0$ & 6 & $21 \pm 0$ & 11 & $13,2 \pm 1$ & 7 & $5,9 \pm 1,8$ \\
6 & 5 & $21 \pm 0$ & 6 & $21 \pm 0$ & 11 & $14,3 \pm 1,2$ & 7 & $5,9 \pm 1,8$ \\
7 & 5 & $21 \pm 0$ & 6 & $21 \pm 0$ & 11 & $14,4 \pm 1,2$ & 7 & $6,3 \pm 1,9$ \\
8 & 5 & $21 \pm 0$ & 6 & $21 \pm 0$ & 11 & $15 \pm 1,2$ & 7 & $6,3 \pm 1,9$ \\
\hline
\end{tabular}

Projeto Piloto - Filamentos de Von Frey

\begin{tabular}{|c|c|c|c|c|c|c|c|c|}
\hline \multicolumn{9}{|c|}{ Patas Anteriores } \\
\hline & \multicolumn{2}{|r|}{ Controle } & \multicolumn{2}{|r|}{ Sham } & \multicolumn{2}{|r|}{ Lesão Leve } & \multicolumn{2}{|c|}{ Lesão Moderada } \\
\hline Semanas & $\mathbf{N}$ & Média \pm e.p.m. & $\mathbf{N}$ & Média \pm e.p.m. & $\mathbf{N}$ & Média \pm e.p.m. & $\mathbf{N}$ & Média \pm e.p.m. \\
\hline 1 & 5 & $13,1 \pm 0,8$ & 6 & $11,7 \pm 0$ & 11 & $14,1 \pm 0,5$ & 7 & $13,7 \pm 0,7$ \\
\hline 2 & 5 & $11,7 \pm 0$ & 6 & $12,4 \pm 1,3$ & 11 & $10,6 \pm 0,6$ & 7 & $12,2 \pm 0,5$ \\
\hline 3 & 5 & $13,1 \pm 0,8$ & 6 & $14,0 \pm 0,7$ & 11 & $12,9 \pm 0,5$ & 7 & $13,2 \pm 0,7$ \\
\hline 4 & 5 & $12,4 \pm 0,7$ & 6 & $14,0 \pm 0,7$ & 11 & $13,3 \pm 0,5$ & 7 & $12,2 \pm 0,5$ \\
\hline 5 & 5 & $12,4 \pm 0,7$ & 6 & $12,3 \pm 0,6$ & 11 & $12,7 \pm 0,5$ & 7 & $11,3 \pm 0,9$ \\
\hline 6 & 5 & $13,8 \pm 0,8$ & 6 & $12,3 \pm 1,0$ & 11 & $12,9 \pm 0,5$ & 7 & $12,2 \pm 0,5$ \\
\hline 7 & 5 & $12,4 \pm 0,7$ & 6 & $12,3 \pm 0,6$ & 11 & $12,7 \pm 0,6$ & 7 & $12,2 \pm 0,5$ \\
\hline 8 & 5 & $11,7 \pm 0$ & 6 & $10,7 \pm 0,7$ & 11 & $12,1 \pm 0,3$ & 7 & $12,2 \pm 0,5$ \\
\hline \multicolumn{9}{|c|}{ Patas Posteriores } \\
\hline & \multicolumn{2}{|r|}{ Controle } & \multicolumn{2}{|r|}{ Sham } & \multicolumn{2}{|r|}{ Lesão Leve } & \multicolumn{2}{|c|}{ Lesão Moderada } \\
\hline Semanas & $\mathbf{N}$ & Média \pm e.p.m. & $\mathbf{N}$ & Média \pm e.p.m. & $\mathbf{N}$ & Média \pm e.p.m. & $\mathbf{N}$ & Média \pm e.p.m. \\
\hline 1 & 5 & $12,4 \pm 0,7$ & 6 & $9,3 \pm 0,8$ & 11 & $6,9 \pm 0,9$ & 7 & $6,7 \pm 1,4$ \\
\hline 2 & 5 & $11,7 \pm 0$ & 6 & $9,1 \pm 1,7$ & 11 & $6,2 \pm 1,0$ & 7 & $5,8 \pm 0,9$ \\
\hline 3 & 5 & $8,8 \pm 0,3$ & 6 & $10,9 \pm 0,8$ & 11 & $4,5 \pm 0,5$ & 7 & $3,6 \pm 0,6$ \\
\hline 4 & 5 & $9,5 \pm 0,6$ & 6 & $12,6 \pm 0,6$ & 11 & $5,9 \pm 0,8$ & 7 & $4,5 \pm 1,0$ \\
\hline 5 & 5 & $9,5 \pm 0,8$ & 6 & $9,6 \pm 0,5$ & 11 & $5,8 \pm 0,7$ & 7 & $4,5 \pm 0,8$ \\
\hline 6 & 5 & $10,5 \pm 0,9$ & 6 & $10,1 \pm 0,7$ & 11 & $5,9 \pm 0,8$ & 7 & $3,8 \pm 0,3$ \\
\hline 7 & 5 & $11,1 \pm 0,6$ & 6 & $10,1 \pm 0,7$ & 11 & $7,1 \pm 1,0$ & 7 & $2,7 \pm 0,5$ \\
\hline 8 & 5 & $10,5 \pm 1,2$ & 6 & $10,1 \pm 0,7$ & 11 & $5,6 \pm 0,8$ & 7 & $3,0 \pm 0,5$ \\
\hline
\end{tabular}




\begin{tabular}{|c|c|c|c|c|c|c|c|c|}
\hline \multicolumn{9}{|c|}{ Projeto Piloto - Retirada da Cauda } \\
\hline \multirow[b]{2}{*}{ Semanas } & \multicolumn{2}{|r|}{ Controle } & \multicolumn{2}{|r|}{ Sham } & \multicolumn{2}{|r|}{ Lesão Leve } & \multicolumn{2}{|c|}{ Lesão Moderada } \\
\hline & $\mathbf{N}$ & Média \pm e.p.m. & $\mathbf{N}$ & Média \pm e.p.m. & $\mathbf{N}$ & Média \pm e.p.m. & $\mathbf{N}$ & Média \pm e.p.m. \\
\hline 1 & 5 & $5,7 \pm 0,2$ & 6 & $6,2 \pm 0,5$ & 11 & $6,2 \pm 0,3$ & 8 & $5,1 \pm 0,5$ \\
\hline 2 & 5 & $4,9 \pm 0,4$ & 6 & $4,9 \pm 0,3$ & 11 & $5,6 \pm 0,3$ & 7 & $5,1 \pm 0,5$ \\
\hline 3 & 5 & $6,1 \pm 0,4$ & 6 & $5,5 \pm 0,5$ & 11 & $5,4 \pm 0,3$ & 7 & $4,5 \pm 0,3$ \\
\hline 4 & 5 & $5,2 \pm 0,3$ & 6 & $5,9 \pm 0,4$ & 11 & $5,0 \pm 0,3$ & 7 & $3,8 \pm 0,2$ \\
\hline 5 & 5 & $4,9 \pm 0,3$ & 6 & $5,3 \pm 0,4$ & 11 & $4,9 \pm 0,3$ & 7 & $4,4 \pm 0,3$ \\
\hline 6 & 5 & $6,1 \pm 0,6$ & 6 & $6,4 \pm 0,2$ & 11 & $4,7 \pm 0,3$ & 7 & $4,7 \pm 0,3$ \\
\hline 7 & 5 & $5 \pm 0,5$ & 6 & $5,4 \pm 0,4$ & 11 & $4,9 \pm 0,3$ & 7 & $5,9 \pm 0,3$ \\
\hline 8 & 5 & $5,5 \pm 0,3$ & 6 & $6,1 \pm 0,5$ & 11 & $4,8 \pm 0,3$ & 7 & $5,3 \pm 0,5$ \\
\hline
\end{tabular}

\section{Projeto Piloto - Contagem de Células ( $\mathrm{N}^{\circ}$ de Neurônios)}

\begin{tabular}{c|c|c|c|c|c|c|c|c}
\hline & \multicolumn{2}{|c|}{ Controle } & \multicolumn{3}{c|}{ Sham } & \multicolumn{2}{|c|}{ Lesão Leve } & \multicolumn{2}{c}{ Lesão Moderada } \\
\hline & $\mathbf{N}$ & Média \pm e.p.m. & $\mathbf{N}$ & Média \pm e.p.m. & N & Média \pm e.p.m. & N & Média \pm e.p.m. \\
\hline $\begin{array}{c}\text { Acima } \\
\text { da lesão }\end{array}$ & 10 & $671,2 \pm 7,9$ & 12 & $697,3 \pm 12,32$ & 18 & $657,7 \pm 9,3$ & 14 & $651,9 \pm 14,6$ \\
$\begin{array}{c}\text { Área } \\
\text { da lesão }\end{array}$ & 30 & $754,1 \pm 10,1$ & 36 & $766,9 \pm 10,9$ & 56 & $337,6 \pm 31,9$ & 42 & $182,5 \pm 23,3$ \\
$\begin{array}{c}\text { Abaixo } \\
\text { da lesão }\end{array}$ & 10 & $739,9 \pm 5,5$ & 12 & $786,4 \pm 12,7$ & 10 & $740,7 \pm 20,8$ & 9 & $731,0 \pm 19,9$ \\
\hline
\end{tabular}

\begin{tabular}{c|c|c|c}
\hline \multicolumn{2}{c}{ Projeto Piloto - Tamanho da Lesão $(\mathrm{cm})$} \\
\hline \multicolumn{2}{c|}{ Lesão Leve } & \multicolumn{2}{c}{ Lesão Moderada } \\
\hline $\mathbf{N}$ & Média \pm e.p.m. & $\mathbf{N}$ & Média \pm e.p.m. \\
\hline 10 & $5,6 \pm 0,8$ & 6 & $6,5 \pm 0,2$ \\
\hline
\end{tabular}




\subsection{Dados Estatísticos do Projeto Principal}

Dados referentes às análises do projeto principal. Os valores estão apresentados como média aritmética \pm erro padrão da média.

\begin{tabular}{c|c|c|c|c|c|c|c|c}
\hline \multicolumn{7}{|c}{ Projeto Principal - Peso (\%) } \\
\hline & \multicolumn{2}{|c|}{ Controle } & \multicolumn{2}{c|}{ Sham } & \multicolumn{2}{c|}{ VT } & \multicolumn{2}{c}{ BV } \\
\hline Semanas & N & Média \pm e.p.m. & N & Média \pm e.p.m. & N & Média \pm e.p.m. & N & Média \pm e.p.m. \\
\hline Pré-lesão & 14 & $100 \pm 0$ & 11 & $100 \pm 0$ & 12 & $100 \pm 0$ & 11 & $100 \pm 0$ \\
Pré-transp & 14 & $109,7 \pm 1,0$ & 11 & $95,0 \pm 1,6$ & 12 & $98,3 \pm 1,8$ & 11 & $97,5 \pm 3,8$ \\
1 & 14 & $121,5 \pm 1,9$ & 11 & $100,9 \pm 2,4$ & 12 & $100,5 \pm 2,4$ & 11 & $96,8 \pm 2,3$ \\
2 & 14 & $124,8 \pm 2,7$ & 11 & $105,6 \pm 3,6$ & 11 & $105,3 \pm 2,7$ & 10 & $98,4 \pm 4,3$ \\
3 & 13 & $121,5 \pm 4,3$ & 11 & $109,7 \pm 4,5$ & 10 & $111,6 \pm 4,2$ & 7 & $107,7 \pm 7,0$ \\
4 & 10 & $120,8 \pm 4,5$ & 9 & $120,0 \pm 4,2$ & 9 & $117,0 \pm 6,2$ & 6 & $119,9 \pm 3,7$ \\
5 & 7 & $126,2 \pm 7,2$ & 9 & $121,4 \pm 4,4$ & 7 & $117,4 \pm 8,4$ & 5 & $123,5 \pm 2,2$ \\
6 & 6 & $125,3 \pm 9,3$ & 9 & $122,8 \pm 5,1$ & 6 & $122,2 \pm 10,3$ & 5 & $121,5 \pm 3,6$ \\
7 & 5 & $125,2 \pm 9,9$ & 8 & $116,0 \pm 5,5$ & 5 & $123,6 \pm 11,9$ & 5 & $119,7 \pm 5,2$ \\
8 & 5 & $123,4 \pm 10,1$ & 7 & $116,5 \pm 6,8$ & 5 & $123,5 \pm 10,9$ & 5 & $121,2 \pm 7,7$ \\
\hline
\end{tabular}

\begin{tabular}{c|c|c|c|c|c|c|c|c}
\hline \multicolumn{8}{c}{ Controle } & \multicolumn{2}{c|}{ Sham } & \multicolumn{2}{c}{ VT } & \multicolumn{2}{c}{ BV } \\
\hline & \multicolumn{2}{|c|}{ Crojeto Principal - BBB } \\
\hline Semanas & N & Média \pm e.p.m. & N & Média \pm e.p.m. & N & Média \pm e.p.m. & N & Média \pm e.p.m. \\
\hline Pré-lesão & 14 & $21 \pm 0$ & 11 & $21 \pm 0$ & 12 & $21 \pm 0$ & 11 & $21 \pm 0$ \\
Pré-transp & 14 & $21 \pm 0$ & 11 & $5,4 \pm 1,3$ & 12 & $6,3 \pm 1,3$ & 11 & $5,5 \pm 0,9$ \\
1 & 14 & $21 \pm 0$ & 11 & $9,0 \pm 0,6$ & 12 & $8,1 \pm 1,3$ & 11 & $8,5 \pm 0,7$ \\
2 & 14 & $21 \pm 0$ & 11 & $9,9 \pm 0,6$ & 11 & $8,9 \pm 1,4$ & 10 & $10,1 \pm 0,4$ \\
3 & 13 & $21 \pm 0$ & 10 & $10,7 \pm 0,5$ & 10 & $9,8 \pm 1,7$ & 7 & $11,6 \pm 0,3$ \\
4 & 9 & $21 \pm 0$ & 9 & $10,6 \pm 0,8$ & 9 & $10,3 \pm 1,8$ & 6 & $11,7 \pm 0,3$ \\
5 & 7 & $21 \pm 0$ & 9 & $10,6 \pm 0,8$ & 7 & $11,1 \pm 1,8$ & 5 & $11,5 \pm 0,5$ \\
6 & 6 & $21 \pm 0$ & 9 & $10,7 \pm 0,9$ & 6 & $11,2 \pm 1,8$ & 5 & $13,2 \pm 1,0$ \\
7 & 5 & $21 \pm 0$ & 8 & $11,1 \pm 1,2$ & 5 & $12,4 \pm 2,1$ & 5 & $13,6 \pm 1,0$ \\
8 & 5 & $21 \pm 0$ & 7 & $11,4 \pm 1,4$ & 5 & $12,4 \pm 2,1$ & 5 & $16,6 \pm 1,0$ \\
\hline
\end{tabular}




\begin{tabular}{|c|c|c|c|c|c|c|c|c|}
\hline \multicolumn{9}{|c|}{ Projeto Principal - Plano Inclinado } \\
\hline & \multicolumn{2}{|r|}{ Controle } & \multicolumn{2}{|r|}{ Sham } & \multicolumn{2}{|r|}{ VT } & \multicolumn{2}{|r|}{ BV } \\
\hline Semanas & $\mathbf{N}$ & Média \pm e.p.m. & $\mathbf{N}$ & Média \pm e.p.m. & $\mathbf{N}$ & Média \pm e.p.m. & $\mathbf{N}$ & Média \pm e.p.m. \\
\hline Pré-lesão & 14 & $75,7 \pm 0,9$ & 11 & $75,4 \pm 1,0$ & 12 & $75,4 \pm 1,6$ & 11 & $75,4 \pm 0,8$ \\
\hline Pré-transp & 14 & $77,5 \pm 1,0$ & 11 & $41,1 \pm 1,5$ & 12 & $47,5 \pm 2,6$ & 11 & $46,4 \pm 1,8$ \\
\hline 1 & 14 & $73,6 \pm 0,6$ & 11 & $48,6 \pm 1,7$ & 12 & $53,7 \pm 1,9$ & 11 & $51,8 \pm 2,2$ \\
\hline 2 & 14 & $75,7 \pm 0,9$ & 11 & $54,5 \pm 2,2$ & 11 & $57,7 \pm 2,5$ & 10 & $56,5 \pm 2,6$ \\
\hline 3 & 13 & $80,8 \pm 1,1$ & 10 & $57,0 \pm 2,4$ & 10 & $60,0 \pm 2,9$ & 7 & $59,3 \pm 3,2$ \\
\hline 4 & 10 & $78,5 \pm 1,3$ & 9 & $59,4 \pm 2,7$ & 9 & $61,1 \pm 3,0$ & 6 & $62,5 \pm 3,1$ \\
\hline 5 & 7 & $77,1 \pm 1,5$ & 9 & $59,4 \pm 2,3$ & 7 & $62,1 \pm 3,2$ & 5 & $66,2 \pm 3,1$ \\
\hline 6 & 6 & $78,3 \pm 1,7$ & 9 & $62,2 \pm 2,2$ & 6 & $64,2 \pm 3,3$ & 5 & $66,2 \pm 1,2$ \\
\hline 7 & 5 & $81,0 \pm 1,9$ & 8 & $62,5 \pm 2,3$ & 5 & $67,0 \pm 3,7$ & 5 & $67,0 \pm 3,4$ \\
\hline 8 & 5 & $80,0 \pm 0$ & 7 & $64,3 \pm 2,8$ & 5 & $65,0 \pm 3,9$ & 5 & $69,0 \pm 2,4$ \\
\hline
\end{tabular}




\begin{tabular}{|c|c|c|c|c|c|c|c|c|}
\hline \multicolumn{9}{|c|}{ Projeto Principal - Monitor de Atividades } \\
\hline \multicolumn{9}{|c|}{ Distância } \\
\hline & \multicolumn{2}{|r|}{ Controle } & \multicolumn{2}{|r|}{ Sham } & \multicolumn{2}{|r|}{ VT } & \multicolumn{2}{|r|}{ BV } \\
\hline Semanas & $\mathbf{N}$ & Média \pm e.p.m. & $\mathbf{N}$ & Média \pm e.p.m. & $\mathbf{N}$ & Média \pm e.p.m. & $\mathbf{N}$ & Média \pm e.p.m. \\
\hline Pré-transp & 14 & $4,0 \pm 0,4$ & 11 & $2,3 \pm 0,2$ & 12 & $2,6 \pm 0,4$ & 11 & $2,9 \pm 0,3$ \\
\hline 1 & 14 & $4,9 \pm 0,5$ & 11 & $2,4 \pm 0,4$ & 12 & $2,3 \pm 0,4$ & 11 & $2,3 \pm 0,5$ \\
\hline 2 & 14 & $5,00,4$ & 11 & $1,9 \pm 0,4$ & 10 & $3,4 \pm 0,6$ & 10 & $1,6 \pm 0,2$ \\
\hline 3 & 13 & $3,9 \pm 0,5$ & 10 & $1,8 \pm 0,3$ & 9 & $3,3 \pm 0,5$ & 7 & $2,9 \pm 0,6$ \\
\hline 4 & 10 & $3,3 \pm 0,4$ & 9 & $2,4 \pm 0,3$ & 9 & $2,4 \pm 0,5$ & 6 & $3,1 \pm 0,4$ \\
\hline 5 & 5 & $2,5 \pm 0,8$ & 9 & $2,3 \pm 0,3$ & 7 & $2,6 \pm 0,7$ & 4 & $3,2 \pm 0,4$ \\
\hline 6 & 8 & $3,9 \pm 0,9$ & 9 & $2,3 \pm 0,6$ & 6 & $2,1 \pm 0,6$ & 4 & $2,1 \pm 0,5$ \\
\hline 7 & 4 & $0,8 \pm 0,2$ & 5 & $3,9 \pm 1,0$ & 5 & $3,3 \pm 0,8$ & 5 & $2,7 \pm 0,5$ \\
\hline 8 & 5 & $2,7 \pm 0,9$ & 7 & $2,9 \pm 0,8$ & 5 & $2,7 \pm 0,7$ & 5 & $2,5 \pm 0,5$ \\
\hline \multicolumn{9}{|c|}{ Velocidade } \\
\hline & \multicolumn{2}{|r|}{ Controle } & \multicolumn{2}{|r|}{ Sham } & \multicolumn{2}{|r|}{ VT } & \multicolumn{2}{|r|}{ BV } \\
\hline Semanas & $\mathbf{N}$ & Média \pm e.p.m. & $\mathbf{N}$ & Média \pm e.p.m. & $\mathbf{N}$ & Média \pm e.p.m. & $\mathbf{N}$ & Média \pm e.p.m. \\
\hline Pré-transp & 14 & $19,8 \pm 1,5$ & 11 & $9,9 \pm 0,9$ & 12 & $13,3 \pm 1,9$ & 11 & $11,12 \pm 1,0$ \\
\hline 1 & 14 & $20,9 \pm 1,5$ & 11 & $10,8 \pm 1,5$ & 12 & $14,1 \pm 2,6$ & 11 & $9,7 \pm 1,4$ \\
\hline 2 & 14 & $19,9 \pm 1,7$ & 11 & $10,1 \pm 1,8$ & 10 & $12,4 \pm 1,9$ & 10 & $7,9 \pm 0,9$ \\
\hline 3 & 13 & $17,4 \pm 1,8$ & 10 & $8,9 \pm 1,2$ & 9 & $11,5 \pm 1,8$ & 7 & $10,7 \pm 2,0$ \\
\hline 4 & 10 & $15,5 \pm 1,4$ & 9 & $8,8 \pm 1,0$ & 9 & $8,9 \pm 1,7$ & 6 & $11,9 \pm 0,9$ \\
\hline 5 & 5 & $10,9 \pm 2,4$ & 9 & $9,1 \pm 1,1$ & 7 & $10,6 \pm 2,2$ & 4 & $10,9 \pm 1,7$ \\
\hline 6 & 6 & $15,7 \pm 3,8$ & 9 & $10,11 \pm 2,1$ & 6 & $8,2 \pm 2,3$ & 4 & $9,4 \pm 0,9$ \\
\hline 7 & 4 & $8,3 \pm 1,7$ & 5 & $14,7 \pm 3,2$ & 5 & $11,9 \pm 3,1$ & 5 & $10,3 \pm 1,6$ \\
\hline 8 & 5 & $12,7 \pm 2,1$ & 7 & $11,6 \pm 2,2$ & 5 & $10,07 \pm 2,5$ & 5 & $8,6 \pm 1,5$ \\
\hline \multicolumn{9}{|c|}{ Apoio Bipodal } \\
\hline & \multicolumn{2}{|r|}{ Controle } & \multicolumn{2}{|r|}{ Sham } & \multicolumn{2}{|r|}{ VT } & \multicolumn{2}{|r|}{ BV } \\
\hline Semanas & $\mathbf{N}$ & Média \pm e.p.m. & $\mathbf{N}$ & Média \pm e.p.m. & $\mathbf{N}$ & Média \pm e.p.m. & $\mathbf{N}$ & Média \pm e.p.m. \\
\hline Pré-transp & 14 & $6,0 \pm 0,4$ & 11 & $2,4 \pm 0,7$ & 12 & $2,3 \pm 0,6$ & 11 & $3,3 \pm 1,3$ \\
\hline 1 & 14 & $6,4 \pm 0,7$ & 11 & $0,4 \pm 0,2$ & 12 & $1,3 \pm 0,5$ & 11 & $1,6 \pm 0,6$ \\
\hline 2 & 14 & $5,3 \pm 0,8$ & 11 & $0,4 \pm 0,2$ & 10 & $1,1 \pm 0,5$ & 10 & $0,2 \pm 0,1$ \\
\hline 3 & 13 & $3,9 \pm 0,8$ & 10 & $0,8 \pm 0,4$ & 9 & $0,8 \pm 0,4$ & 7 & $0 \pm 0$ \\
\hline 4 & 10 & $2,8 \pm 0,6$ & 9 & $0,4 \pm 0,2$ & 9 & $0,6 \pm 0,3$ & 6 & $0,3 \pm 0,2$ \\
\hline 5 & 7 & $2,7 \pm 1,1$ & 9 & $0,3 \pm 0,2$ & 7 & $0,1 \pm 0,1$ & 4 & $0 \pm 0$ \\
\hline 6 & 6 & $4,3 \pm 1,7$ & 9 & $0,2 \pm 0,1$ & 6 & $0,2 \pm 0,2$ & 4 & $0 \pm 0$ \\
\hline 7 & 5 & $1,4 \pm 0,7$ & 5 & $0,8 \pm 0,6$ & 5 & $0,6 \pm 0,4$ & 5 & $0,2 \pm 0,2$ \\
\hline 8 & 5 & $2,2 \pm 1,2$ & 7 & $0,3 \pm 0,3$ & 5 & $0,4 \pm 0,2$ & 5 & $0 \pm 0$ \\
\hline
\end{tabular}




\section{Projeto Principal - Filamentos de Von Frey}

Patas Anteriores

\begin{tabular}{|c|c|c|c|c|c|c|c|c|}
\hline & \multicolumn{2}{|r|}{ Controle } & \multicolumn{2}{|r|}{ Sham } & \multicolumn{2}{|r|}{ VT } & \multicolumn{2}{|r|}{ BV } \\
\hline Semanas & $\mathbf{N}$ & Média \pm e.p.m. & $\mathbf{N}$ & Média \pm e.p.m. & $\mathbf{N}$ & Média \pm e.p.m. & $\mathbf{N}$ & Média \pm e.p.m. \\
\hline Pré-lesão & 28 & $8,7 \pm 0,2$ & 22 & $8,8 \pm 0,2$ & 24 & $9,6 \pm 0,3$ & 22 & $9,1 \pm 0,3$ \\
\hline Pré-transp & 28 & $8,7 \pm 0,2$ & 22 & $9,1 \pm 0,3$ & 23 & $10,1 \pm 0,4$ & 22 & $9,9 \pm 0,3$ \\
\hline 1 & 28 & $8,5 \pm 0$ & 22 & $9,1 \pm 0,3$ & 24 & $8,8 \pm 0,2$ & 22 & $9,6 \pm 0,4$ \\
\hline 2 & 28 & $10,8 \pm 0,3$ & 22 & $9,4 \pm 0,3$ & 22 & $8,5 \pm 0$ & 20 & $8,5 \pm 0$ \\
\hline 3 & 26 & $8,5 \pm 0,2$ & 22 & $9,1 \pm 0,3$ & 20 & $8,8 \pm 0,2$ & 14 & $9,9 \pm 0,4$ \\
\hline 4 & 20 & $8,8 \pm 0,2$ & 18 & $9,9 \pm 0,4$ & 18 & $9,2 \pm 0,3$ & 12 & $9,0 \pm 0,4$ \\
\hline 5 & 14 & $8,1 \pm 0,3$ & 18 & $8,9 \pm 0,2$ & 14 & $8,9 \pm 0,5$ & 10 & $8,5 \pm 0$ \\
\hline 6 & 12 & $9,6 \pm 0,5$ & 18 & $8,9 \pm 0,4$ & 12 & $9,2 \pm 0,5$ & 10 & $8,5 \pm 0$ \\
\hline 7 & 10 & $9,2 \pm 0,4$ & 16 & $8,9 \pm 0,3$ & 10 & $9,2 \pm 0,4$ & 10 & $9,8 \pm 0,5$ \\
\hline 8 & 10 & $8,5 \pm 0$ & 14 & $8,5 \pm 0$ & 10 & $9,2 \pm 0,4$ & 10 & $8,5 \pm 0$ \\
\hline \multicolumn{9}{|c|}{ Patas Posteriores } \\
\hline & \multicolumn{2}{|r|}{ Controle } & \multicolumn{2}{|r|}{ Sham } & \multicolumn{2}{|r|}{ VT } & \multicolumn{2}{|r|}{ BV } \\
\hline Semanas & $\mathbf{N}$ & Média \pm e.p.m. & $\mathbf{N}$ & Média \pm e.p.m. & $\mathbf{N}$ & Média \pm e.p.m. & $\mathbf{N}$ & Média \pm e.p.m. \\
\hline Pré-lesão & 28 & $8,5 \pm 0,2$ & 22 & $8,4 \pm 0,1$ & 24 & $8,1 \pm 0,3$ & 22 & $8,4 \pm 0,1$ \\
\hline Pré-transp & 28 & $8,5 \pm 0,2$ & 22 & $2,9 \pm 0,5$ & 23 & $3,1 \pm 0,3$ & 22 & $2,1 \pm 0,2$ \\
\hline 1 & 28 & $9,0 \pm 0,5$ & 22 & $3,6 \pm 0,6$ & 24 & $2,2 \pm 0,2$ & 22 & $2,6 \pm 0,3$ \\
\hline 2 & 28 & $9,2 \pm 0,3$ & 22 & $2,9 \pm 0,4$ & 22 & $1,7 \pm 0,1$ & 20 & $1,7 \pm 0,1$ \\
\hline 3 & 26 & $8,7 \pm 0,3$ & 22 & $1,9 \pm 0,2$ & 20 & $1,8 \pm 0,1$ & 14 & $2,0 \pm 0,3$ \\
\hline 4 & 20 & $8,8 \pm 0,2$ & 18 & $1,8 \pm 0,2$ & 18 & $2,0 \pm 0,1$ & 12 & $2,2 \pm 0,2$ \\
\hline 5 & 14 & $7,0 \pm 0,4$ & 18 & $2,1 \pm 0,2$ & 14 & $2,3 \pm 0,3$ & 10 & $2,8 \pm 0,5$ \\
\hline 6 & 12 & $8,0 \pm 0,3$ & 18 & $2,7 \pm 0,5$ & 12 & $2,7 \pm 0,4$ & 10 & $1,9 \pm 0,1$ \\
\hline 7 & 10 & $9,2 \pm 0,4$ & 15 & $3,1 \pm 0,5$ & 10 & $4,4 \pm 0,7$ & 10 & $2,4 \pm 0,4$ \\
\hline 8 & 10 & $8,2 \pm 0,3$ & 14 & $3,1 \pm 0,4$ & 10 & $4,7 \pm 0,8$ & 10 & $4,6 \pm 1,1$ \\
\hline
\end{tabular}




\section{Projeto Principal - Placa Quente}

\begin{tabular}{c|c|c|c|c|c|c|c|c}
\hline & \multicolumn{2}{|c|}{ Controle } & \multicolumn{2}{c|}{ Sham } & \multicolumn{2}{c}{ VT } & \multicolumn{2}{c}{ BV } \\
\hline Semanas & N & Média \pm e.p.m. & N & Média \pm e.p.m. & N & Média \pm e.p.m. & N & Média \pm e.p.m. \\
\hline Pré-lesão & 28 & $12 \pm 0,3$ & 22 & $11,7 \pm 0,2$ & 24 & $12,5 \pm 0,2$ & 22 & $12,3 \pm 0,3$ \\
Pré-transp & 28 & $11,9 \pm 0,2$ & 22 & $6,3 \pm 0,7$ & 22 & $7,0 \pm 0,4$ & 22 & $7,1 \pm 0,5$ \\
1 & 28 & $13,9 \pm 0,4$ & 22 & $7,6 \pm 0,3$ & 24 & $5,3 \pm 0,3$ & 22 & $5,7 \pm 0,3$ \\
2 & 28 & $11,2 \pm 0,2$ & 22 & $5,4 \pm 0,3$ & 22 & $4,9 \pm 0,2$ & 20 & $6,0 \pm 0,3$ \\
3 & 26 & $11,2 \pm 0,2$ & 20 & $4,2 \pm 0,2$ & 20 & $4,6 \pm 0,4$ & 14 & $5,0 \pm 0,5$ \\
4 & 20 & $12,3 \pm 0,5$ & 18 & $3,9 \pm 0,2$ & 16 & $4,6 \pm 0,3$ & 12 & $5,3 \pm 0,4$ \\
5 & 14 & $11,1 \pm 0,5$ & 18 & $4,0 \pm 0,2$ & 14 & $5,1 \pm 0,4$ & 8 & $5,7 \pm 0,6$ \\
6 & 12 & $12,3 \pm 0,5$ & 18 & $4,5 \pm 0,3$ & 12 & $5,3 \pm 0,6$ & 8 & $5,0 \pm 0,5$ \\
7 & 10 & $13,6 \pm 0,9$ & 16 & $4,2 \pm 0,3$ & 10 & $6,3 \pm 0,7$ & 11 & $6,2 \pm 0,5$ \\
8 & 10 & $11,8 \pm 0,4$ & 14 & $4,1 \pm 0,2$ & 10 & $6,1 \pm 0,5$ & 11 & $6,6 \pm 0,5$ \\
\hline
\end{tabular}

\begin{tabular}{c|c|c|c|c}
\hline \multicolumn{5}{c}{ Projeto Principal - Estereologia } \\
\hline & \multicolumn{2}{|c|}{ VT } & \multicolumn{2}{c}{ BV } \\
\hline & N & Média \pm e.p.m. & N & Média \pm e.p.m. \\
\hline NeuN & 33 & $69,4 \pm 4,7$ & 78 & $72,1 \pm 3,3$ \\
GFAP & 20 & $9,7 \pm 2,9$ & 25 & $22,5 \pm 5,0$ \\
Oligodendrócito & 19 & $23,2 \pm 5,2$ & 15 & $25,9 \pm 5,1$ \\
GABA & 24 & $29 \pm 3,7$ & 39 & $18,6 \pm 2,7$ \\
5HT & 36 & $9,9 \pm 3,0$ & 43 & $33,9 \pm 4,9$ \\
Encefalina & 40 & $30,7 \pm 2,6$ & 45 & $35,9 \pm 2,4$ \\
\hline
\end{tabular}


REFERÊNCIAS 


\section{REFERÊNCIAS}

Abercrombie M. Estimation of nuclear population from microtome sections. Anat Rec. 1946; 94: 239-47.

Ackery A, Tator C and Krassioukov A. A global perspective on spinal cord injury epidemiology. J Neurotrauma. 2004; 21(10): 1355-70.

Ahmed MM, Lee H, Clark Z, Miranpuri GS, Nacht C, Patel K, Liu L, Joslin J, Kintner D and Resnick DK. Pathogenesis of spinal cord injury induced edema and neuropathic pain: expression of multiple isoforms of wnk1. Ann Neurosci. 2014; 21(3): 97-103.

Aleynik A, Gernavage KM, Mourad Y, Sherman LS, Liu K, Gubenko YA and Rameshwar P. Stem cell delivery of therapies for brain disorders. Clin Transl Med. 2014; 3: 24.

Andresen SR, Biering-Sorensen F, Hagen EM, Nielsen JF, Bach FW and Finnerup NB. Pain, spasticity and quality of life in individuals with traumatic spinal cord injury in Denmark. Spinal Cord. 2016; 54(11): 973-979.

ASIA (2002). International Standards for Neurological Classification of SCI (ISNCSCI) Worksheet.

Baastrup C and Finnerup NB. Pharmacological management of neuropathic pain following spinal cord injury. CNS Drugs. 2008; 22(6): 455-75.

Basbaum Al, Bautista DM, Scherrer G and Julius D. Cellular and molecular mechanisms of pain. Cell. 2009; 139(2): 267-84.

Basbaum Al and Fields HL. Endogenous pain control mechanisms: review and hypothesis. Ann Neurol. 1978; 4(5): 451-62.

Basso DM, Beattie MS, Bresnahan JC, Anderson DK, Faden Al, Gruner JA, Holford TR, Hsu CY, Noble LJ, Nockels R, Perot PL, Salzman SK and Young W. MASCIS evaluation of open field locomotor scores: effects of experience and teamwork on reliability. Multicenter Animal Spinal Cord Injury Study. J Neurotrauma. 1996; 13(7): 343-59.

Batchelor PE, Wills TE, Skeers P, Battistuzzo CR, Macleod MR, Howells DW and Sena ES. Meta-analysis of pre-clinical studies of early decompression in acute spinal cord injury: a battle of time and pressure. PLoS One. 2013; 8(8): e72659.

Batista CE, Mariano ED, Marie SK, Teixeira MJ, Morgalla M, Tatagiba M, Li J and Lepski G. Stem cells in neurology--current perspectives. Arq Neuropsiquiatr. 2014; 72(6): 457-65. 
Battiwalla $\mathrm{M}$ and Hematti $\mathrm{P}$. Mesenchymal stem cells in hematopoietic stem cell transplantation. Cytotherapy. 2009; 11(5): 503-15.

Beattie MS, Hermann GE, Rogers RC and Bresnahan JC. Cell death in models of spinal cord injury. Prog Brain Res. 2002; 137: 37-47.

Berrocal YA, Almeida VW, Puentes R, Knott EP, Hechtman JF, Garland M and Pearse DD. Loss of central inhibition: implications for behavioral hypersensitivity after contusive spinal cord injury in rats. Pain Res Treat. 2014; 2014: 178278.

Bongso $A$ and Richards $M$. History and perspective of stem cell research. Best Pract Res Clin Obstet Gynaecol. 2004; 18(6): 827-42.

Boroujerdi A, Zeng J, Sharp K, Kim D, Steward O and Luo ZD. Calcium channel alpha-2-delta-1 protein upregulation in dorsal spinal cord mediates spinal cord injury-induced neuropathic pain states. Pain. 2011; 152(3): 649-55.

Bracken MB. Steroids for acute spinal cord injury. Cochrane Database Syst Rev. 2012; 1: CD001046.

Bradbury EJ, Moon LD, Popat RJ, King VR, Bennett GS, Patel PN, Fawcett JW and McMahon SB. Chondroitinase ABC promotes functional recovery after spinal cord injury. Nature. 2002; 416(6881): 636-40.

Breasted JH. Edwin Smith Surgical Papyrus: University of Chicago Press; 1930.

Brown A and Weaver LC. The dark side of neuroplasticity. Exp Neurol. 2012; 235(1): 133-41.

Bruce JC, Oatway MA and Weaver LC. Chronic pain after clip-compression injury of the rat spinal cord. Exp Neurol. 2002; 178(1): 33-48.

Bunge RP. Clinical implications of recent advances in neurotrauma research. The neurobiology of central nervous system trauma. Oxford Univ. Press, New York. 1994: 328-339.

Bunge RP, Puckett WR, Becerra JL, Marcillo A and Quencer RM. Observations on the pathology of human spinal cord injury. A review and classification of 22 new cases with details from a case of chronic cord compression with extensive focal demyelination. Adv Neurol. 1993; 59: 75-89.

Burns AS, Rivas DA and Ditunno JF. The management of neurogenic bladder and sexual dysfunction after spinal cord injury. Spine (Phila Pa 1976). 2001; 26(24 Suppl): S129-36.

Carlson GD, Minato Y, Okada A, Gorden CD, Warden KE, Barbeau JM, Biro CL, Bahnuik E, Bohlman $\mathrm{HH}$ and Lamanna JC. Early time-dependent decompression for spinal cord injury: vascular mechanisms of recovery. J Neurotrauma. 1997; 14(12): 951-62. 
Carlson NG, Rojas MA, Redd JW, Tang P, Wood B, Hill KE and Rose JW. Cyclooxygenase-2 expression in oligodendrocytes increases sensitivity to excitotoxic death. J Neuroinflammation. 2010; 7: 25.

Changeux J-P. O Homem Neuronal: Publicações Dom Quixote; 1985.

Chao CY and Cheing GL. The effects of lower-extremity functional electric stimulation on the orthostatic responses of people with tetraplegia. Arch Phys Med Rehabil. 2005; 86(7): 1427-33.

Chaplan SR, Bach FW, Pogrel JW, Chung JM and Yaksh TL. Quantitative assessment of tactile allodynia in the rat paw. J Neurosci Methods. 1994; 53(1): 55-63.

Chatzipanteli K, Garcia R, Marcillo AE, Loor KE, Kraydieh S and Dietrich WD. Temporal and segmental distribution of constitutive and inducible nitric oxide synthases after traumatic spinal cord injury: effect of aminoguanidine treatment. $J$ Neurotrauma. 2002; 19(5): 639-51.

Cheriyan T, Ryan DJ, Weinreb JH, Cheriyan J, Paul JC, Lafage V, Kirsch T and Errico TJ. Spinal cord injury models: a review. Spinal Cord. 2014; 52(8): 588-95.

Chiou SH, Jiang BH, Yu YL, Chou SJ, Tsai PH, Chang WC, Chen LK, Chen LH, Chien $Y$ and Chiou GY. Poly(ADP-ribose) polymerase 1 regulates nuclear reprogramming and promotes iPSC generation without c-Myc. J Exp Med. 2013; 210(1): 85-98.

Christensen MD, Everhart AW, Pickelman JT and Hulsebosch CE. Mechanical and thermal allodynia in chronic central pain following spinal cord injury. Pain. 1996; 68(1): 97-107.

Christensen MD and Hulsebosch CE. Chronic central pain after spinal cord injury. J Neurotrauma. 1997; 14(8): 517-37.

Claydon VE and Krassioukov AV. Orthostatic hypotension and autonomic pathways after spinal cord injury. J Neurotrauma. 2006; 23(12): 1713-25.

Colachis SC, 3rd and Otis SM. Occurrence of fever associated with thermoregulatory dysfunction after acute traumatic spinal cord injury. Am J Phys Med Rehabil. 1995; 74(2): 114-9.

Corleto JA, Bravo-Hernandez M, Kamizato K, Kakinohana O, Santucci C, Navarro MR, Platoshyn O, Cizkova D, Lukacova N, Taylor J and Marsala M. Thoracic 9 Spinal Transection-Induced Model of Muscle Spasticity in the Rat: A Systematic Electrophysiological and Histopathological Characterization. PLOS One. 2015; 10(12): e0144642.

Costigan M, Scholz $\mathrm{J}$ and Woolf CJ. Neuropathic pain: a maladaptive response of the nervous system to damage. Annu Rev Neurosci. 2009; 32: 1-32. 
Cunha TM and Dias QM. Glial modulation of pain: a step beyond. $J$ Neurosci. 2009; 29(11): 3340-2.

Dale CS, Pagano Rde L, Paccola CC, Pinotti-Guirao T, Juliano MA, Juliano L and Giorgi R. Effect of the C-terminus of murine S100A9 protein on experimental nociception. Peptides. 2006; 27(11): 2794-802.

Davies JE, Proschel C, Zhang N, Noble M, Mayer-Proschel M and Davies SJ. Transplanted astrocytes derived from BMP- or CNTF-treated glial-restricted precursors have opposite effects on recovery and allodynia after spinal cord injury. J Biol. 2008; 7(7): 24.

Densmore VS, Kalous A, Keast JR and Osborne PB. Above-level mechanical hyperalgesia in rats develops after incomplete spinal cord injury but not after cord transection, and is reversed by amitriptyline, morphine and gabapentin. Pain. 2010; 151(1): 184-93.

Ditunno JF, Little JW, Tessler A and Burns AS. Spinal shock revisited: a fourphase model. Spinal Cord. 2004; 42(7): 383-95.

Donnelly DJ and Popovich PG. Inflammation and its role in neuroprotection, axonal regeneration and functional recovery after spinal cord injury. Exp Neurol. 2008; 209(2): 378-88.

Donovan $\mathrm{J}$ and Kirshblum S. Clinical Trials in Traumatic Spinal Cord Injury. Neurotherapeutics. 2018.

Drew GM, Siddall PJ and Duggan AW. Mechanical allodynia following contusion injury of the rat spinal cord is associated with loss of GABAergic inhibition in the dorsal horn. Pain. 2004; 109(3): 379-88.

Eftekharpour E, Karimi-Abdolrezaee S and Fehlings MG. Current status of experimental cell replacement approaches to spinal cord injury. Neurosurg Focus. 2008; 24(3-4): E19.

Falnikar A, Hala TJ, Poulsen DJ and Lepore AC. GLT1 overexpression reverses established neuropathic pain-related behavior and attenuates chronic dorsal horn neuron activation following cervical spinal cord injury. Glia. 2016; 64(3): 396-406.

Fandel TM, Trivedi A, Nicholas CR, Zhang H, Chen J, Martinez AF, NobleHaeusslein LJ and Kriegstein AR. Transplanted Human Stem Cell-Derived Interneuron Precursors Mitigate Mouse Bladder Dysfunction and Central Neuropathic Pain after Spinal Cord Injury. Cell Stem Cell. 2016; 19(4): 544-557.

Fawcett JW and Asher RA. The glial scar and central nervous system repair. Brain Res Bull. 1999; 49(6): 377-91.

Figley SA, Khosravi R, Legasto JM, Tseng YF and Fehlings MG. Characterization of vascular disruption and blood-spinal cord barrier permeability following traumatic spinal cord injury. J Neurotrauma. 2014; 31(6): 541-52. 
Finnerup NB. Pain in patients with spinal cord injury. Pain. 2013; 154 Suppl 1: S71-6.

Finnerup NB, Johannesen IL, Sindrup SH, Bach FW and Jensen TS. Pain and dysesthesia in patients with spinal cord injury: A postal survey. Spinal Cord. 2001; 39(5): 256-62.

Fuentealba LC, Rompani SB, Parraguez Jl, Obernier K, Romero R, Cepko CL and Alvarez-Buylla A. Embryonic Origin of Postnatal Neural Stem Cells. Cell. 2015; 161(7): 1644-55.

Gage FH. Mammalian neural stem cells. Science. 2000; 287(5457): 1433-8.

Garstang SV and Miller-Smith SA. Autonomic nervous system dysfunction after spinal cord injury. Phys Med Rehabil Clin N Am. 2007; 18(2): 275-96, vi-vii.

Ge S, Goh EL, Sailor KA, Kitabatake Y, Ming GL and Song H. GABA regulates synaptic integration of newly generated neurons in the adult brain. Nature. 2006; 439(7076): 589-93.

Gerardo-Nava J, Mayorenko, II, Grehl T, Steinbusch HW, Weis J and Brook GA. Differential pattern of neuroprotection in lumbar, cervical and thoracic spinal cord segments in an organotypic rat model of glutamate-induced excitotoxicity. $J$ Chem Neuroanat. 2013; 53: 11-7.

Gold MS and Gebhart GF. Nociceptor sensitization in pain pathogenesis. Nat Med. 2010; 16(11): 1248-57.

Gomelsky A, Lemack GE, Castano Botero JC, Lee RK, Myers JB, Granitsiotis P and Dmochowski RR. Current and future international patterns of care of neurogenic bladder after spinal cord injury. World J Urol. 36(10): 1613-1619.

Grigorean VT, Sandu AM, Popescu M, lacobini MA, Stoian R, Neascu C, Strambu $V$ and Popa F. Cardiac dysfunctions following spinal cord injury. J Med Life. 2009; 2(2): 133-45.

Gruner JA. A monitored contusion model of spinal cord injury in the rat. $J$ Neurotrauma. 1992; 9(2): 123-6; discussion 126-8.

Guan Y. Spinal cord stimulation: neurophysiological and neurochemical mechanisms of action. Curr Pain Headache Rep. 2012; 16(3): 217-25.

Hagg $\mathrm{T}$ and Oudega $\mathrm{M}$. Degenerative and spontaneous regenerative processes after spinal cord injury. J Neurotrauma. 2006; 23(3-4): 264-80.

Hamid R, Averbeck MA, Chiang H, Garcia A, Al Mousa RT, Oh SJ, Patel A, Plata $\mathrm{M}$ and Del Popolo G. Epidemiology and pathophysiology of neurogenic bladder after spinal cord injury. World $J$ Urol. 
Herrmann JE, Imura T, Song B, Qi J, Ao Y, Nguyen TK, Korsak RA, Takeda K, Akira S and Sofroniew MV. STAT3 is a critical regulator of astrogliosis and scar formation after spinal cord injury. J Neurosci. 2008; 28(28): 7231-43.

Hofstetter CP, Holmstrom NA, Lilja JA, Schweinhardt P, Hao J, Spenger C, Wiesenfeld-Hallin Z, Kurpad SN, Frisen $\mathrm{J}$ and Olson L. Allodynia limits the usefulness of intraspinal neural stem cell grafts; directed differentiation improves outcome. Nat Neurosci. 2005; 8(3): 346-53.

Holtz KA, Lipson R, Noonan VK, Kwon BK and Mills PB. Prevalence and Effect of Problematic Spasticity After Traumatic Spinal Cord Injury. Arch Phys Med Rehabil. 2017; 98(6): 1132-1138.

Hosseinkhani M, Shirazi R, Rajaei F, Mahmoudi M, Mohammadi N and Abbasi M. Engineering of the embryonic and adult stem cell niches. Iran Red Crescent Med J. 2013; 15(2): 83-92.

Hughes JT. The Edwin Smith Surgical Papyrus:An analysis of the first case reports of spinal cord injuries. Paraplegia. 1988; 26: 71-82.

Hulsebosch CE, Xu GY, Perez-Polo JR, Westlund KN, Taylor CP and McAdoo DJ. Rodent model of chronic central pain after spinal cord contusion injury and effects of gabapentin. J Neurotrauma. 2000; 17(12): 1205-17.

Hwang I, Hahm SC, Choi KA, Park SH, Jeong H, Yea JH, Kim J and Hong S. Intrathecal Transplantation of Embryonic Stem Cell-Derived Spinal GABAergic Neural Precursor Cells Attenuates Neuropathic Pain in a Spinal Cord Injury Rat Model. Cell Transplant. 2016; 25(3): 593-607.

Jiang Y, Zhang MJ and Hu BY. Specification of functional neurons and glia from human pluripotent stem cells. Protein Cell. 2012; 3(11): 818-25.

Jones LL, Sajed D and Tuszynski MH. Axonal regeneration through regions of chondroitin sulfate proteoglycan deposition after spinal cord injury: a balance of permissiveness and inhibition. J Neurosci. 2003; 23(28): 9276-88.

Jozefczyk PB. The management of focal spasticity. Clin Neuropharmacol. 2002; 25(3): 158-73.

Kakulas BA. Neuropathology: the foundation for new treatments in spinal cord injury. Spinal Cord. 2004; 42(10): 549-63.

Kandel E, Schwartz J, Jessell T, Siegelbaum S and Hudspeth A. Principles of neural science: McGrawHill; 2012.

Karimi-Abdolrezaee S, Eftekharpour E, Wang J, Schut D and Fehlings MG. Synergistic effects of transplanted adult neural stem/progenitor cells, chondroitinase, and growth factors promote functional repair and plasticity of the chronically injured spinal cord. J Neurosci. 2010; 30(5): 1657-76. 
Karlsson AK. Autonomic dysreflexia. Spinal Cord. 1999; 37(6): 383-91.

Karlsson AK. Autonomic dysfunction in spinal cord injury: clinical presentation of symptoms and signs. Prog Brain Res. 2006; 152: 1-8.

Keane RW, Kraydieh S, Lotocki G, Bethea JR, Krajewski S, Reed JC and Dietrich WD. Apoptotic and anti-apoptotic mechanisms following spinal cord injury. $J$ Neuropathol Exp Neurol. 2001; 60(5): 422-9.

Kim HJ and Park JS. Usage of Human Mesenchymal Stem Cells in Cell-based Therapy: Advantages and Disadvantages. Dev Reprod. 2017; 21(1): 1-10.

Kirshblum S. Treatment alternatives for spinal cord injury related spasticity. J Spinal Cord Med. 1999; 22(3): 199-217.

Kramer JL, Minhas NK, Jutzeler CR, Erskine EL, Liu LJ and Ramer MS. Neuropathic pain following traumatic spinal cord injury: Models, measurement, and mechanisms. J Neurosci Res. 2017; 95(6): 1295-1306.

Krassioukov A and Claydon VE. The clinical problems in cardiovascular control following spinal cord injury: an overview. Prog Brain Res. 2006; 152: 223-9.

Krassioukov A and Elliott S. Neural Control and Physiology of Sexual Function: Effect of Spinal Cord Injury. Top Spinal Cord Inj Rehabil. 2017; 23(1): 1-10.

Krassioukov AV, Karlsson AK, Wecht JM, Wuermser LA, Mathias CJ, Marino RJ, Joint Committee of American Spinal Injury A and International Spinal Cord S. Assessment of autonomic dysfunction following spinal cord injury: rationale for additions to International Standards for Neurological Assessment. J Rehabil Res Dev. 2007; 44(1): 103-12.

Kumagai G, Tsoulfas P, Toh S, McNiece I, Bramlett HM and Dietrich WD. Genetically modified mesenchymal stem cells (MSCs) promote axonal regeneration and prevent hypersensitivity after spinal cord injury. Exp Neurol. 2013; 248: 369-80.

Kumar R, Lim J, Mekary RA, Rattani A, Dewan MC, Sharif SY, Osorio-Fonseca E and Park KB. Traumatic Spinal Injury: Global Epidemiology and Worldwide Volume. World Neurosurg. 2018; 113: e345-e363.

Kwon BK, Oxland TR and Tetzlaff W. Animal models used in spinal cord regeneration research. Spine (Phila Pa 1976). 2002; 27(14): 1504-10.

Kwon BK and Tetzlaff W. Spinal cord regeneration: from gene to transplants. Spine (Phila Pa 1976). 2001; 26(24 Suppl): S13-22.

Lance JW. What is spasticity? Lancet. 1990; 335(8689): 606. 
Laszlo Z, Rossler A and Hinghofer-Szalkay HG. Cardiovascular and hormonal changes with different angles of head-up tilt in men. Physiol Res. 2001; 50(1): 71 82.

Latremoliere A and Woolf CJ. Central sensitization: a generator of pain hypersensitivity by central neural plasticity. J Pain. 2009; 10(9): 895-926.

Leem JW, Kim HK, Hulsebosch CE and Gwak YS. Ionotropic glutamate receptors contribute to maintained neuronal hyperexcitability following spinal cord injury in rats. Exp Neurol. 2010; 224(1): 321-4.

Lemons ML, Howland DR and Anderson DK. Chondroitin sulfate proteoglycan immunoreactivity increases following spinal cord injury and transplantation. Exp Neurol. 1999; 160(1): 51-65.

Lepski G, Jannes CE, Maciaczyk J, Papazoglou A, Mehlhorn AT, Kaiser S, Teixeira MJ, Marie SK, Bischofberger $\mathrm{J}$ and Nikkhah $\mathrm{G}$. Limited Ca2+ and PKApathway dependent neurogenic differentiation of human adult mesenchymal stem cells as compared to fetal neuronal stem cells. Exp Cell Res. 2010; 316(2): 21631.

Lepski G, Jannes CE, Nikkhah G and Bischofberger J. cAMP promotes the differentiation of neural progenitor cells in vitro via modulation of voltage-gated calcium channels. Front Cell Neurosci. 2013; 7: 155.

Lepski G, Jannes CE, Wessolleck J, Kobayashi E and Nikkhah G. Equivalent neurogenic potential of wild-type and GFP-labeled fetal-derived neural progenitor cells before and after transplantation into the rodent hippocampus. Transplantation. 2011; 91(4): 390-7.

Li J and Lepski G. Cell transplantation for spinal cord injury: a systematic review. Biomed Res Int. 2013; 2013: 786475.

Li JY, Christophersen NS, Hall V, Soulet D and Brundin P. Critical issues of clinical human embryonic stem cell therapy for brain repair. Trends Neurosci. 2008; 31 (3): 146-53.

Llado J, Haenggeli C, Maragakis NJ, Snyder EY and Rothstein JD. Neural stem cells protect against glutamate-induced excitotoxicity and promote survival of injured motor neurons through the secretion of neurotrophic factors. Mol Cell Neurosci. 2004; 27(3): 322-31.

Loeser JD and Treede RD. The Kyoto protocol of IASP Basic Pain Terminology. Pain. 2008; 137(3): 473-7.

Lundy-Ekman L. Neurociência: Fundamentos para a reabilitação. Rio de Janeiro; 2008. 
Luo Y, Zou Y, Yang L, Liu J, Liu S, Zhou X, Zhang W and Wang T. Transplantation of NSCs with OECs alleviates neuropathic pain associated with NGF downregulation in rats following spinal cord injury. Neurosci Lett. 2013; 549: 103-8.

Maciaczyk J, Singec I, Maciaczyk D, Klein A and Nikkhah G. Restricted spontaneous in vitro differentiation and region-specific migration of long-term expanded fetal human neural precursor cells after transplantation into the adult rat brain. Stem Cells Dev. 2009; 18(7): 1043-58.

Maciaczyk J, Singec I, Maciaczyk D and Nikkhah G. Combined use of BDNF, ascorbic acid, low oxygen, and prolonged differentiation time generates tyrosine hydroxylase-expressing neurons after long-term in vitro expansion of human fetal midbrain precursor cells. Exp Neurol. 2008; 213(2): 354-62.

Macias MY, Syring MB, Pizzi MA, Crowe MJ, Alexanian AR and Kurpad SN. Pain with no gain: allodynia following neural stem cell transplantation in spinal cord injury. Exp Neurol. 2006; 201 (2): 335-48.

McCorry LK. Physiology of the autonomic nervous system. Am J Pharm Educ. 2007; 71(4): 78.

McDonald JW, Becker D, Sadowsky CL, Jane JA, Sr., Conturo TE and Schultz LM. Late recovery following spinal cord injury. Case report and review of the literature. J Neurosurg. 2002; 97(2 Suppl): 252-65.

Mehlhorn AT, Schmal H, Kaiser S, Lepski G, Finkenzeller G, Stark GB and Sudkamp NP. Mesenchymal stem cells maintain TGF-beta-mediated chondrogenic phenotype in alginate bead culture. Tissue Eng. 2006; 12(6): 1393403.

Meisner JG, Marsh AD and Marsh DR. Loss of GABAergic interneurons in laminae I-III of the spinal cord dorsal horn contributes to reduced GABAergic tone and neuropathic pain after spinal cord injury. J Neurotrauma. 2010; 27(4): 729-37.

Merskey HB, N. (2014). Classification of chronic pain: descriptions of chronic pain syndromes and definitions of pain terms._. Seattle, IASP Press.

Morgan MM, Heinricher MM and Fields HL. Circuitry linking opioid-sensitive nociceptive modulatory systems in periaqueductal gray and spinal cord with rostral ventromedial medulla. Neuroscience. 1992; 47(4): 863-71.

Nielsen JB, Crone $\mathrm{C}$ and Hultborn $\mathrm{H}$. The spinal pathophysiology of spasticity-from a basic science point of view. Acta Physiol (Oxf). 2007; 189(2): 171-80.

Norenberg MD, Smith $\mathrm{J}$ and Marcillo A. The pathology of human spinal cord injury: defining the problems. J Neurotrauma. 2004; 21(4): 429-40.

NSCISC. National Spinal Cord Injury Statistical Center, Facts and Figures at a Glance. 2018. 
Park E, Velumian AA and Fehlings MG. The role of excitotoxicity in secondary mechanisms of spinal cord injury: a review with an emphasis on the implications for white matter degeneration. J Neurotrauma. 2004; 21(6): 754-74.

Parziale JR, Akelman E and Herz DA. Spasticity: pathophysiology and management. Orthopedics. 1993; 16(7): 801-11.

Pineau I and Lacroix S. Proinflammatory cytokine synthesis in the injured mouse spinal cord: multiphasic expression pattern and identification of the cell types involved. J Comp Neurol. 2007; 500(2): 267-85.

Polejaeva I and Mitalipov S. Stem cell potency and the ability to contribute to chimeric organisms. Reproduction. 2013; 145(3): R81-8.

Poon PC, Gupta D, Shoichet MS and Tator CH. Clip compression model is useful for thoracic spinal cord injuries: histologic and functional correlates. Spine (Phila Pa 1976). 2007; 32(25): 2853-9.

Popa C, Popa F, Grigorean VT, Onose G, Sandu AM, Popescu M, Burnei G, Strambu $V$ and Sinescu C. Vascular dysfunctions following spinal cord injury. J Med Life. 2010; 3(3): 275-85.

Putatunda R, Hala TJ, Chin J and Lepore AC. Chronic at-level thermal hyperalgesia following rat cervical contusion spinal cord injury is accompanied by neuronal and astrocyte activation and loss of the astrocyte glutamate transporter, GLT1, in superficial dorsal horn. Brain Res. 2014; 1581: 64-79.

Raghavendra V, Tanga $F$ and DeLeo JA. Inhibition of microglial activation attenuates the development but not existing hypersensitivity in a rat model of neuropathy. J Pharmacol Exp Ther. 2003; 306(2): 624-30.

Ratajczak MZ, Zuba-Surma E, Kucia M, Poniewierska A, Suszynska M and Ratajczak J. Pluripotent and multipotent stem cells in adult tissues. Adv Med Sci. 2012; 57(1): 1-17.

Rekand T, Hagen EM and Gronning M. Chronic pain following spinal cord injury. Tidsskr Nor Laegeforen. 2012; 132(8): 974-9.

Rivlin AS and Tator $\mathrm{CH}$. Objective clinical assessment of motor function after experimental spinal cord injury in the rat. J Neurosurg. 1977; 47(4): 577-81.

Rivlin AS and Tator $\mathrm{CH}$. Effect of duration of acute spinal cord compression in a new acute cord injury model in the rat. Surg Neurol. 1978; 10(1): 38-43.

Roh DH, Seo MS, Choi HS, Park SB, Han HJ, Beitz AJ, Kang KS and Lee JH. Transplantation of human umbilical cord blood or amniotic epithelial stem cells alleviates mechanical allodynia after spinal cord injury in rats. Cell Transplant. 2013; 22(9): 1577-90. 
Rowland JW, Hawryluk GW, Kwon B and Fehlings MG. Current status of acute spinal cord injury pathophysiology and emerging therapies: promise on the horizon. Neurosurg Focus. 2008; 25(5): E2.

Saadeh YS, Smith BW, Joseph JR, Jaffer SY, Buckingham MJ, Oppenlander ME, Szerlip NJ and Park P. The impact of blood pressure management after spinal cord injury: a systematic review of the literature. Neurosurg Focus. 2017; 43(5): E20.

Sakamoto A, Ohnishi ST, Ohnishi T and Ogawa R. Relationship between free radical production and lipid peroxidation during ischemia-reperfusion injury in the rat brain. Brain Res. 1991; 554(1-2): 186-92.

Scheifer C, Hoheisel U, Trudrung P, Unger T and Mense S. Rats with chronic spinal cord transection as a possible model for the at-level pain of paraplegic patients. Neurosci Lett. 2002; 323(2): 117-20.

Schmidt KD and Chan CW. Thermoregulation and fever in normal persons and in those with spinal cord injuries. Mayo Clin Proc. 1992; 67(5): 469-75.

Schnell L, Fearn S, Schwab ME, Perry VH and Anthony DC. Cytokine-induced acute inflammation in the brain and spinal cord. J Neuropathol Exp Neurol. 1999; 58(3): $245-54$

Schweigreiter R and Bandtlow CE. Nogo in the injured spinal cord. J Neurotrauma. 2006; 23(3-4): 384-96.

Shaikh A, Phadke CP, Ismail F and Boulias C. Relationship Between Botulinum Toxin, Spasticity, and Pain: a Survey of Patient Perception. Can J Neurol Sci. 2016; 43(2): 311-5.

Siddall $\mathrm{P}, \mathrm{Xu} \mathrm{CL}$ and Cousins M. Allodynia following traumatic spinal cord injury in the rat. Neuroreport. 1995; 6(9): 1241-4.

Siddall PJ, McClelland JM, Rutkowski SB and Cousins MJ. A longitudinal study of the prevalence and characteristics of pain in the first 5 years following spinal cord injury. Pain. 2003; 103(3): 249-57.

Siddiqui AM, Khazaei $M$ and Fehlings MG. Translating mechanisms of neuroprotection, regeneration, and repair to treatment of spinal cord injury. Prog Brain Res. 2015; 218: 15-54.

Sjolund $\mathrm{BH}$. Pain and rehabilitation after spinal cord injury: the case of sensory spasticity? Brain Res Brain Res Rev. 2002; 40(1-3): 250-6.

Skold C, Levi R and Seiger A. Spasticity after traumatic spinal cord injury: nature, severity, and location. Arch Phys Med Rehabil. 1999; 80(12): 1548-57. 
Soni BM, Vaidyanthan S, Watt JW and Krishnan KR. A retrospective study of hyponatremia in tetraplegic/paraplegic patients with a review of the literature. Paraplegia. 1994; 32(9): 597-607.

Stocks JM, Taylor NA, Tipton MJ and Greenleaf JE. Human physiological responses to cold exposure. Aviat Space Environ Med. 2004; 75(5): 444-57.

Stoodley MA. Pathophysiology of syringomyelia. J Neurosurg. 2000; 92(6): 106970; author reply 1071-3.

Surani A and Tischler J. Stem cells: a sporadic super state. Nature. 2012; 487(7405): 43-5.

Swijnenburg RJ, Schrepfer S, Govaert JA, Cao F, Ransohoff K, Sheikh AY, Haddad M, Connolly AJ, Davis MM, Robbins RC and Wu JC. Immunosuppressive therapy mitigates immunological rejection of human embryonic stem cell xenografts. Proc Natl Acad Sci U S A. 2008; 105(35): 12991-6.

Takahashi K, Tanabe K, Ohnuki M, Narita M, Ichisaka T, Tomoda K and Yamanaka S. Induction of pluripotent stem cells from adult human fibroblasts by defined factors. Cell. 2007; 131(5): 861-72.

Takahashi $\mathrm{K}$ and Yamanaka S. Induction of pluripotent stem cells from mouse embryonic and adult fibroblast cultures by defined factors. Cell. 2006; 126(4): 66376.

Tan AM, Stamboulian S, Chang YW, Zhao P, Hains AB, Waxman SG and Hains BC. Neuropathic pain memory is maintained by Rac1-regulated dendritic spine remodeling after spinal cord injury. J Neurosci. 2008; 28(49): 13173-83.

Tao F, Li Q, Liu S, Wu H, Skinner J, Hurtado A, Belegu V, Furmanski O, Yang Y, McDonald JW and Johns RA. Role of neuregulin-1/ErbB signaling in stem cell therapy for spinal cord injury-induced chronic neuropathic pain. Stem Cells. 2013; 31(1): 83-91.

Tator $\mathrm{CH}$ and Koyanagi I. Vascular mechanisms in the pathophysiology of human spinal cord injury. J Neurosurg. 1997; 86(3): 483-92.

Teasell RW, Arnold JM, Krassioukov A and Delaney GA. Cardiovascular consequences of loss of supraspinal control of the sympathetic nervous system after spinal cord injury. Arch Phys Med Rehabil. 2000; 81(4): 506-16.

Teixeira MJ, Paiva WS, Assis MS, Fonoff ET, Bor-Seng-Shu E and Cecon AD. Neuropathic pain in patients with spinal cord injury: report of 213 patients. Arq Neuropsiquiatr. 2013; 71(9A): 600-3.

Terman GW, Shavit Y, Lewis JW, Cannon JT and Liebeskind JC. Intrinsic mechanisms of pain inhibition: activation by stress. Science. 1984; 226(4680): 1270-7. 
Tzekou A and Fehlings MG. Treatment of spinal cord injury with intravenous immunoglobulin G: preliminary evidence and future perspectives. J Clin Immunol. 2014; 34 Suppl 1: S132-8.

Vanicky I, Urdzikova L, Saganova K, Cizkova D and Galik J. A simple and reproducible model of spinal cord injury induced by epidural balloon inflation in the rat. J Neurotrauma. 2001; 18(12): 1399-407.

Wang KC, Koprivica V, Kim JA, Sivasankaran R, Guo Y, Neve RL and He Z. Oligodendrocyte-myelin glycoprotein is a Nogo receptor ligand that inhibits neurite outgrowth. Nature. 2002; 417(6892): 941-4.

Watanabe S, Uchida K, Nakajima H, Matsuo H, Sugita D, Yoshida A, Honjoh K, Johnson WE and Baba $\mathrm{H}$. Early transplantation of mesenchymal stem cells after spinal cord injury relieves pain hypersensitivity through suppression of pain-related signaling cascades and reduced inflammatory cell recruitment. Stem Cells. 2015; 33(6): 1902-14.

Wentz de Moura dE, Campos e Silva PdA, Borges D and Lima E. Fisioterapia: Aspectos Clínicos e Práticos da Reabiltação 2009.

Wislet-Gendebien S, Laudet E, Neirinckx V and Rogister B. Adult bone marrow: which stem cells for cellular therapy protocols in neurodegenerative disorders? $J$ Biomed Biotechnol. 2012; 2012: 601560.

Woolf CJ. Central sensitization: implications for the diagnosis and treatment of pain. Pain. 2011; 152(3 Suppl): S2-15.

Yamanaka S. A fresh look at iPS cells. Cell. 2009; 137(1): 13-7.

Yao ZG, Sun XL, Li P, Liu HL, Wu HL, Xi ZQ and Zheng ZH. Neural stem cells transplantation alleviate the hyperalgesia of spinal cord injured $(\mathrm{SCl})$ associated with down-regulation of BDNF. Int J Clin Exp Med. 2015; 8(1): 404-12.

Yip PK and Malaspina A. Spinal cord trauma and the molecular point of no return. Mol Neurodegener. 2012; 7: 6.

Yousefifard M, Nasirinezhad F, Shardi Manaheji H, Janzadeh A, Hosseini M and Keshavarz M. Human bone marrow-derived and umbilical cord-derived mesenchymal stem cells for alleviating neuropathic pain in a spinal cord injury model. Stem Cell Res Ther. 2016; 7: 36.

Yu WR, Liu T, Fehlings TK and Fehlings MG. Involvement of mitochondrial signaling pathways in the mechanism of Fas-mediated apoptosis after spinal cord injury. Eur J Neurosci. 2009; 29(1): 114-31.

Zhao P, Hill M, Liu S, Chen L, Bangalore L, Waxman SG and Tan AM. Dendritic spine remodeling following early and late Rac1 inhibition after spinal cord injury: evidence for a pain biomarker. J Neurophysiol. 2016; 115(6): 2893-910. 
